Dionísio Matrigani Mercado Gutierres

\title{
ANÁLISE DA EVOLUÇÃO DA DEMANDA POR TRANSPORTES ASSOCIADA À IMPLANTAÇÃO DE ESTAÇÕES DE METRÔ
}

\author{
Dissertação apresentada à Escola \\ Politécnica da Universidade de São Paulo \\ para obtenção do título de Mestre em \\ Engenharia de Transportes
}

São Paulo 
Dionísio Matrigani Mercado Gutierres

\section{ANÁLISE DA EVOLUÇÃO DA DEMANDA POR TRANSPORTES ASSOCIADA À IMPLANTAÇÃO DE ESTAÇÕES DE METRÔ}

Dissertação apresentada à Escola

Politécnica da Universidade de São Paulo para obtenção do título de Mestre em Engenharia de Transportes

Orientador:

Prof. Doutor Orlando Strambi 
Este exemplar foi revisado e alterado em relação à versão original, sob responsabilidade única do autor e com a anuência de seu orientador.

São Paulo, 18 de junho de 2013.

Assinatura do autor

Assinatura do orientador

FICHA CATALOGRÁFICA

Gutierres, Dionísio Matrigani Mercado

Análise da evolução do comportamento da demanda por transportes associada à implantação de estações de Metrô / D.M. M. Gutierres. -- versão corr. -- São Paulo, 2013.

$84 \mathrm{p}$.

Dissertação (Mestrado) - Escola Politécnica da Universidade de São Paulo. Departamento de Engenharia de Transportes.

1. Metrô 2. Demanda (Aspectos sócio-econômicos) 3. Transportes (Modelagem) I. Universidade de São Paulo. Escola Politécnica. Departamento de Engenharia de Transportes II. t. 


\section{EPÍGRAFE}

Para todos os planejadores lembrarem sempre o motivo pelo qual trabalham:

“Amanhã será um lindo dia

Da mais louca alegria que se possa imaginar.

Amanhã! Redobrada a força

Pra cima que não cessa. Há de vingar.

Amanhã! Mais nenhum mistério

Acima do ilusório. O astro rei vai brilhar!

Amanhã a luminosidade

Alheia a qualquer vontade há de imperar!

Amanhã está toda a esperança

Por menor que pareça, existe e é pra vicejar

Amanhã, apesar de hoje

Será a estrada que surge pra se trilhar.

Amanhã, mesmo que uns não queiram

Será de outros que esperam ver o dia raiar.

Amanhã! Ódios aplacados.

Temores abrandados. Será pleno!"

Guilherme Arantes 


\section{DEDICATÓRIA}

Dedico este trabalho ao meu primeiro orientador, meu pai. 


\section{AGRADECIMENTOS}

À Universidade de São Paulo, à Escola Politécnica, ao Departamento de Transportes pela criação do ambiente propício ao desenvolvimento deste trabalho, assim como aos professores e colaboradores do departamento. Em especial ao orientador Orlando Strambi, não me esquecendo da secretária do departamento, Patrícia Santana, que tanto auxiliou nos processos burocráticos.

Ao CNPq pelo auxílio dado para a confecção desta dissertação e pelo fomento sempre dado ao conhecimento.

Aos colegas que me acompanharam ao longo desta jornada de estudos na Universidade de São Paulo, que, de alguma maneira, contribuíram para que este trabalho se concretizasse. Em especial, agradeço a Elaine Schneider de Carvalho pelo auxílio na utilização do software Biogeme para estimação de modelos de escolha discreta e a Gláucia Guimarães Pereira pelo auxílio no entendimento de processos metodológicos e estatísticos.

À Companhia do Metropolitano de São Paulo como um todo, pela disponibilização das pesquisas Origem e Destino. Aos companheiros de trabalho do Metrô dedico agradecimento pelo auxílio neste estudo e nos outros muitos que desenvolveremos juntos. Em especial agradeço a Emilia Mayumi Hiroi pelo auxílio na obtenção de dados da O/D utilizando o SPSS, Leonardo Lisboa pelo auxílio na cofecção dos mapas e José França pelo auxílio no entendimento de estimação de modelos de escolha discreta.

Aos amigos, por me apoiaram nos momentos difíceis e sorrirem comigo nos momentos alegres. Poderia citá-los todos, mas prefiro dar a certeza de que estão escritos em meu coração.

Finalmente, aos meus pais, meus primeiros orientadores, e às minhas irmãs, minhas maiores torcedoras. Ao meu amor, por me incentivar simplesmente com sua presença e a toda minha família por ter construído meu caráter. 


\section{RESUMO}

Esta dissertação analisa a evolução da demanda por transportes associada à extensão de duas linhas - Azul e Verde - do Metrô de São Paulo, incluindo cinco estações que iniciaram operação em 1998. A análise usou dados de 1997 e 2007 das Pesquisas Origem e Destino, permitindo a comparação de características de viagem e socioeconômicas. Para cada linha, dois grupos de zonas foram identificadas próximo às novas estações: com impacto direto e com impacto indireto do Metrô. A análise comparou estes grupos geográficos entre eles e temporalmente, usando ambas as Pesquisas OD. Além disso, uma análise desagregada de duas variáveis associadas ao comportamento da demanda por viagem - posse de auto e número de viagens - foi realizada, objetivando identificar o impacto das novas estações. Os resultados indicam que cada extensão de linha se desenvolveu de forma diferente, em termos de distribuição de atividades e características socioeconômicas. Também, a análise desagregada sugere que o efeito de variáveis como renda familiar e distância até a estação mais próxima pode afetar famílias de forma diferente dependendo da proximidade da zona com o Metrô.

Palavras-chave: metrô, demanda por transportes, características socioeconômicas, uso do solo e transportes. 


\begin{abstract}
This dissertation analyzes the evolution of transportation demand associated with the extension of two lines - Blue and Green - of the São Paulo Metro, including five stations that started operating in 1998. The analysis used data from the 1997 and 2007 Origin and Destination Surveys (Pesquisas Origem e Destino), allowing the comparison of travel and socioeconomic characteristics. For each line, two groups of zones were identified in the proximity of the new stations: with direct impact and with indirect impact from the Metrô. The analysis compared these geographic groups between them and in time, using both OD surveys. In addition, a disaggregate analysis of two travel behavior related variables - auto ownership and number of trips - was conducted, aiming to identify the impact of the new stations. The results indicate that each line extension developed differently, in terms of distribution of activities and socioeconomic characteristics. Also, the disaggregate analysis suggests that the effect of variables such as family income and distance to the nearest station may affect families differently depending on the zone proximity to the Metrô.
\end{abstract}

Keywords: subway, transportation demand, socioeconomic characteristics, land use and transport. 


\section{LISTA DE FIGURAS}

Figura 2-1 - Foto aérea de Curitiba ................................................ 18

Figura 2-2 - Foto aérea de Bogotá................................................... 19

Figura 4-1 - Relação entre o zoneamento da O/D1997 e O/D2007 .................33

Figura 4-2. Zonas selecionadas para o estudo no entorno da Linha 1 - Azul ...36

Figura 4-3. Zonas selecionadas para o estudo no entorno da Linha 2 - Verde 36

Figura 5-1 - Comparação da distribuição das famílias em faixas de renda entre Grupo com Metrô, sem Metrô e RMSP - Linha 1 - Azul 48

Figura 5-2 - Motorização familiar média por faixa de renda - Linha 1 - Azul ...49

Figura 5-3 - Comparação da distribuição da população por faixas de renda entre Grupo com Metrô e sem Metro da extensão da Linha 2 - Verde. 58

Figura 5-4 - Motorização familiar média por faixa de renda - Linha 2 - Verde.59

Figura 5-5 - Comparação da distribuição das famílias segundo faixas de renda .65

Figura 5-6 - Comparação da motorização familiar média por faixas de renda..66 


\section{LISTA DE TABELAS}

Tabela 4-1. Zonas selecionadas para o estudo no entorno da Linha 1 - Azul ..35

Tabela 4-2. Zonas selecionadas para o estudo no entorno da Linha 2 - Verde 35

Tabela 5-1. Viagens por modo - Linha 1 - Azul 42

Tabela 5-2. Extremos de viagem por Natureza das atividades - Linha 1 - Azul

Tabela 5-3 - Características Socioeconômicas - Linha 1 - Azul .45

Tabela 5-4 - Distribuição das famílias em faixas de renda - Linha 1 - Azul .....47

Tabela 5-5 - Motorização familiar média por faixa de renda - Linha 1 - Azul ..49

Tabela 5-6 - Taxas de viagens por família segundo faixas de renda - Linha 1 Azul .50

Tabela 5-7. Total de viagens por modo - Linha 2 - Verde .52

Tabela 5-8. Extremos de viagem por Natureza das atividades - Linha 2 - Verde .53

Tabela 5-9 - Características Socioeconômicas - Linha 2 - Verde. 55

Tabela 5-10 - Distribuição de famílias por faixa de renda - Grupo com Metrô Linha 2 - Verde.

Tabela 5-11 - Motorização familiar média por faixa de renda - Linha 2 - Verde 59

Tabela 5-12 - Taxas de viagens por família segundo faixas de renda - Linha 2 - Verde 60

Tabela 5-13 - Comparação da divisão modal 62

Tabela 5-14 - Comparação de Natureza das Atividades. .63

Tabela 5-15 - Comparação de Características Socioeconômicas .64 
Tabela 5-16 - Comparação da distribuição das famílias segundo faixas de renda .65

Tabela 5-17 - Comparação da motorização familiar* média por faixas de renda 66

Tabela 5-18 - Comparação das taxas de viagens por família segundo faixas de renda .67

Tabela 5-19 - Descrição das variáveis do modelo de posse de automóvel .....69

Tabela 5-20 - Estimativas dos modelos da posse de automóvel .....................71

Tabela 5-21 - Descrição das variáveis da regressão linear de viagens familiares .73

Tabela 5-22 - Estimativas das regressões lineares de viagens familiares .......75

Tabela 5-23 - Estimativas das regressões lineares de viagens a pé familiares 


\section{SUMÁRIO}

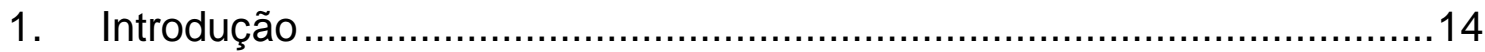

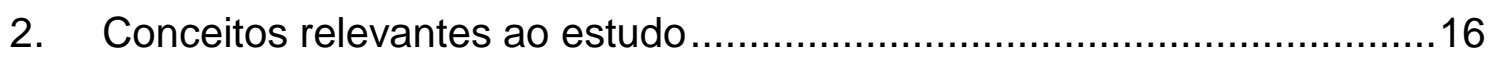

2.1. As novas tendências do urbanismo...............................................16

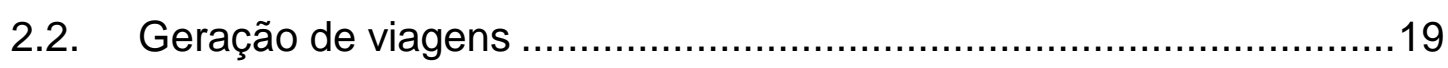

2.3. Conceitos de acessibilidade e mobilidade ......................................20

2.4. Valorização do solo devido à melhoria na acessibilidade....................21

2.5. Os riscos de exclusão social causada pelos transportes ...................24

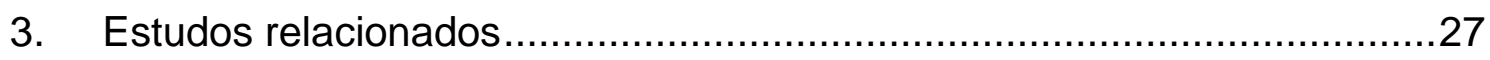

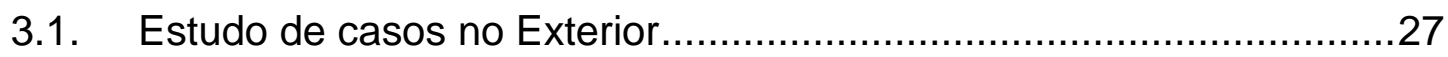

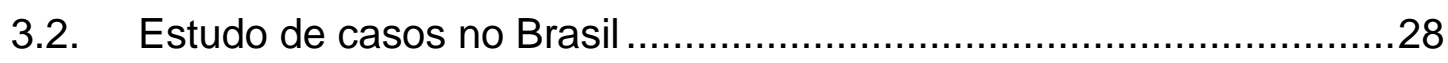

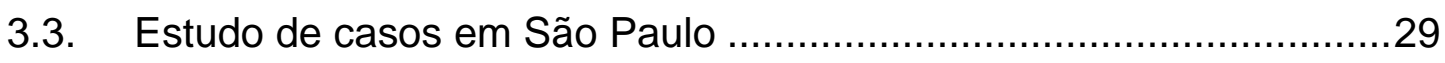

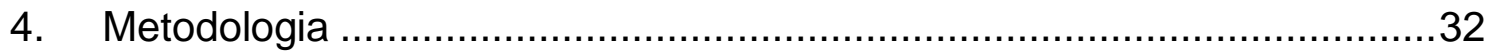

4.1. Delimitação das zonas de estudo ................................................32

4.2. Metodologia para análise das viagens …….................................37

4.3. Metodologia para avaliar a influência de características

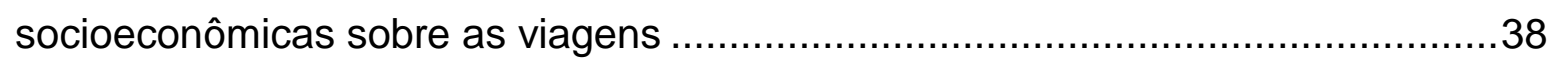

4.4. Metodologia para comparação dos dois casos estudados ..................39

4.5. Metodologia para análise desagregada.........................................39

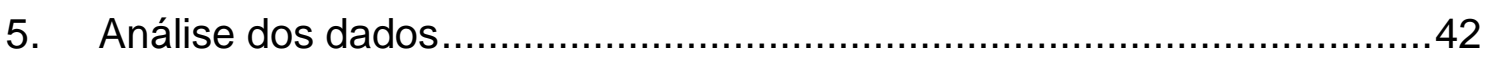

5.1. Estudo do prolongamento da Linha 1 - Azul...................................42

5.1.1. Análise dos modos de viagem ................................................ 42

5.1.2. Análise da Natureza das Atividades ..........................................43

5.1.3. Influência de características socioeconômicas sobre as viagens..45 
5.2. Estudo do prolongamento da Linha 2 - Verde .52

5.2.1. Análise dos modos de viagem

5.2.2. Análise da Natureza das Atividades .53

5.2.3. Influência de características socioeconômicas sobre as viagens..55

5.3. Estudo comparativo dos casos. 62

5.4. Análise desagregada. 69

5.4.1. Influência da proximidade da estação na posse do automóvel ....69

5.4.2. Influência da proximidade da estação nas viagens .73

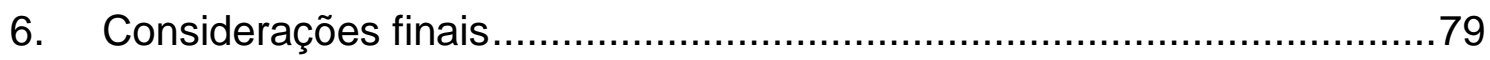

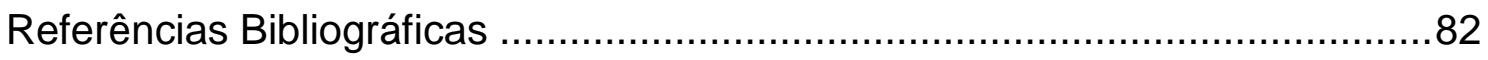

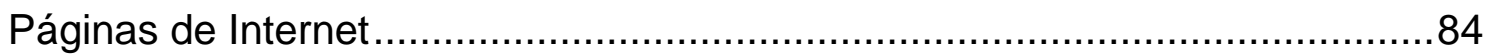




\section{Introdução}

As cidades, em seu crescimento, apresentam disparidades tanto no modo como se desenvolvem, espalhadas ou concentradas, como no uso do solo mais ou menos intenso para certas atividades. Essas características são frutos de vários fatores como topografia, atividades econômicas, possibilidades de exploração de certos bens e acessibilidade.

O transporte, sendo um promotor de acessibilidade, condiciona e é condicionado pelo crescimento das cidades. Um rio, uma ferrovia, uma rodovia podem ter contribuído inicialmente para a localização da cidade. Com o tempo, a complexidade de atividades associada ao crescimento urbano cria a necessidade de novas formas de transportes e o ciclo se reinicia.

A disposição de um meio de transporte, em especial os de alta capacidade, pode se tornar um novo agente modificador. As alterações no entorno de uma estação podem promover mudanças na organização das tarefas diárias dos indivíduos ao afetar o modo como eles se locomovem e os locais para onde eles desejam ir.

Para observar esse fenômeno, esta dissertação considera uma situação ocorrida na cidade de São Paulo em 1998 com a implantação de duas extensões de linha de Metrô, o trecho Santana-Tucuruvi da Linha 1 - Azul e o trecho Clínicas-Vila Madalena da Linha 2 - Verde. O estudo utiliza as pesquisas de demanda por viagem da Região Metropolitana de São Paulo de 1997 e 2007, denominadas Pesquisas Origem e Destino (O/D)

O objetivo deste trabalho é analisar a evolução decorrente da implantação de estações de Metrô na demanda por transportes, assim como suas causas.

Para tanto, os seguintes objetivos específicos se sucedem:

a. Analisar as características das viagens em 1997 e 2007 para as zonas direta e indiretamente afetadas pela inserção das novas estações do Metrô; 
b. Buscar associações para as mudanças encontradas nas características das viagens com a evolução das características socioeconômicas das zonas afetadas;

c. Comparar os casos das duas extensões de linha implantadas no período, verificando semelhanças e especificidades;

d. Analisar outros aspectos do comportamento das famílias associados à implantação das estações do Metrô em análise desagregada.

As mudanças na demanda ocorridas no entorno de uma linha de metrô ou de qualquer outro investimento em transporte apontam para a importância de prever as alterações socioeconômicas e de uso do solo ao se planejar seu desenvolvimento, não deixando que a lógica imobiliária e os interesses financeiros gerenciem sozinhos estas transformações. A proximidade a uma estação do Metrô, por diversas vezes, provoca valorização do uso do solo, atraindo interesse do mercado imobiliário e modificando os usos do entorno.

Este estudo se justifica ao constatar como essas mudanças ocorreram, no caso de São Paulo, sem outras intervenções do poder público, revelando, com maior ou menor intensidade, a influência de outros agentes no desenvolvimento do entorno.

O Capítulo 2 apresenta alguns conceitos de planejamento urbano e planejamento de transportes que serão úteis para o desenvolvimento do trabalho. $O$ Capítulo 3, por sua vez, aborda alguns estudos realizados sobre o comportamento da demanda por viagem associado ao ambiente construído e mudanças no entorno de estações de transportes. O Capítulo 4 descreve a metodologia que foi utilizada para a realização da pesquisa. Os resultados das análises e suas interpretações podem ser encontrados no Capítulo 5. Finalmente, o Capítulo 6 contém as conclusões e considerações finais, assim como recomendações para o desenvolvimento de pesquisas futuras. 


\section{Conceitos relevantes ao estudo}

Neste capítulo, serão apresentados conceitos e ideias que servirão de base para a análise realizada. O enfoque dado aos temas não pretende esgotá-los, somente trazendo base para seu uso no estudo.

\subsection{As novas tendências do urbanismo}

As novas tendências do urbanismo ditam que o ambiente construído, ou seja, todo o espaço que é modificado pelo homem para abrigar suas atividades, deva ser criado e modificado de maneira sustentável.

O relacionamento entre ambiente construído e mudanças no comportamento da demanda por viagem é uma área de pesquisa bastante explorada nos últimos anos. Planejadores urbanos têm analisado novos conceitos conhecidos por New Urbanism, Friendly Neighborhoods e Transit Oriented Development (TOD) visando promover formas urbanas cujos atributos incentivem o uso de modos de transportes alternativos ao automóvel particular (Cervero, 2002).

O New Urbanism é um movimento internacional que visa reformar o desenho do ambiente construído, aumentando a qualidade de vida das pessoas, criando melhores lugares para se viver. Ele envolve consertar e remodelar as cidades, assim como criar novas áreas compactas.

Os princípios do Novo Urbanismo são:

- Melhora da capacidade de realizar viagens a pé (walkability);

- Conectividade para o pedestre e usuário do transporte público;

- Uso misto do solo;

- Diversidade, incluindo pessoas de idades, níveis culturais e sociais distintos;

- Padrões de residência mistos;

- Qualidade arquitetônica e desenho urbano;

- Estrutura de vizinhança tradicional, com um centro comercial, espaços públicos, diversidade de usos a 10 minutos a pé;

- Aumento na densidade;

- Transporte inteligente (smart transportation), conectando cidades e 
bairros que tenham uma relação consolidada;

- Sustentabilidade;

- Qualidade de vida.

Com o aumento dos problemas nas cidades, uma quantidade cada vez maior de estudiosos têm se voltado para essa nova forma de se planejar cidades, alguns deles sendo mencionados posteriormente no Capítulo 3. Maiores informações sobre - New Urbanism podem ser encontradas nos artigos do site http://www.newurbanism.org.

O New Urbanism é um contexto mais amplo de planejamento de cidades, e dentro dele outros conceitos, como o próprio TOD, estão inseridos.

O TOD é uma forma de organizar o espaço no entorno de linhas de transporte, que privilegiam viagens pelo modo coletivo, e criar nesses locais comunidades compactas, que privilegiam viagens a pé. Seus propositores defendem que esta forma de organização do espaço permite um aumento da qualidade de vida, diminuindo a dependência do carro para mobilidade.

Alguns fatores são comuns aos projetos desenvolvidos segundo a lógica do TOD:

- Desenho urbano voltado ao pedestre, incentivando viagens a pé;

- A estação como um equipamento de fundamental importância;

- Um polo regional com usos mistos do solo;

- Alta densidade e desenvolvimento de alta qualidade a 10 minutos a pé;

- Sistema coletor incluindo ônibus, trólebus e outros;

- Desenho urbano também privilegia o uso de bicicletas e motocicletas;

- Estacionamentos a 10 minutos a pé da estação.

Os benefícios comumente associados ao TOD incluem:

- Melhora na qualidade de vida;

- Melhor lugar para viver, trabalhar e ter lazer;

- Melhora na mobilidade dos moradores;

- Aumento nas viagens a pé;

- Diminuição dos congestionamentos;

- Diminuição nos acidentes de trânsito; 
- Diminuição no gasto com transportes;

- Valorização e estabilização das propriedades do entorno;

- Redução na poluição urbana;

- Diminuição na tendência de espalhamento da cidade.

Para exemplificar, permitindo entender melhor a concepção do TOD, cabe mencionar Curitiba, uma cidade mundialmente reconhecida pelo seu sistema de transporte e por ser modelo para vários outros casos de TOD em implantação (Parras, 2006).

A Figura 2-1 ilustra o adensamento ocorrido em Curitiba nos arredores do corredor de ônibus que opera na cidade.

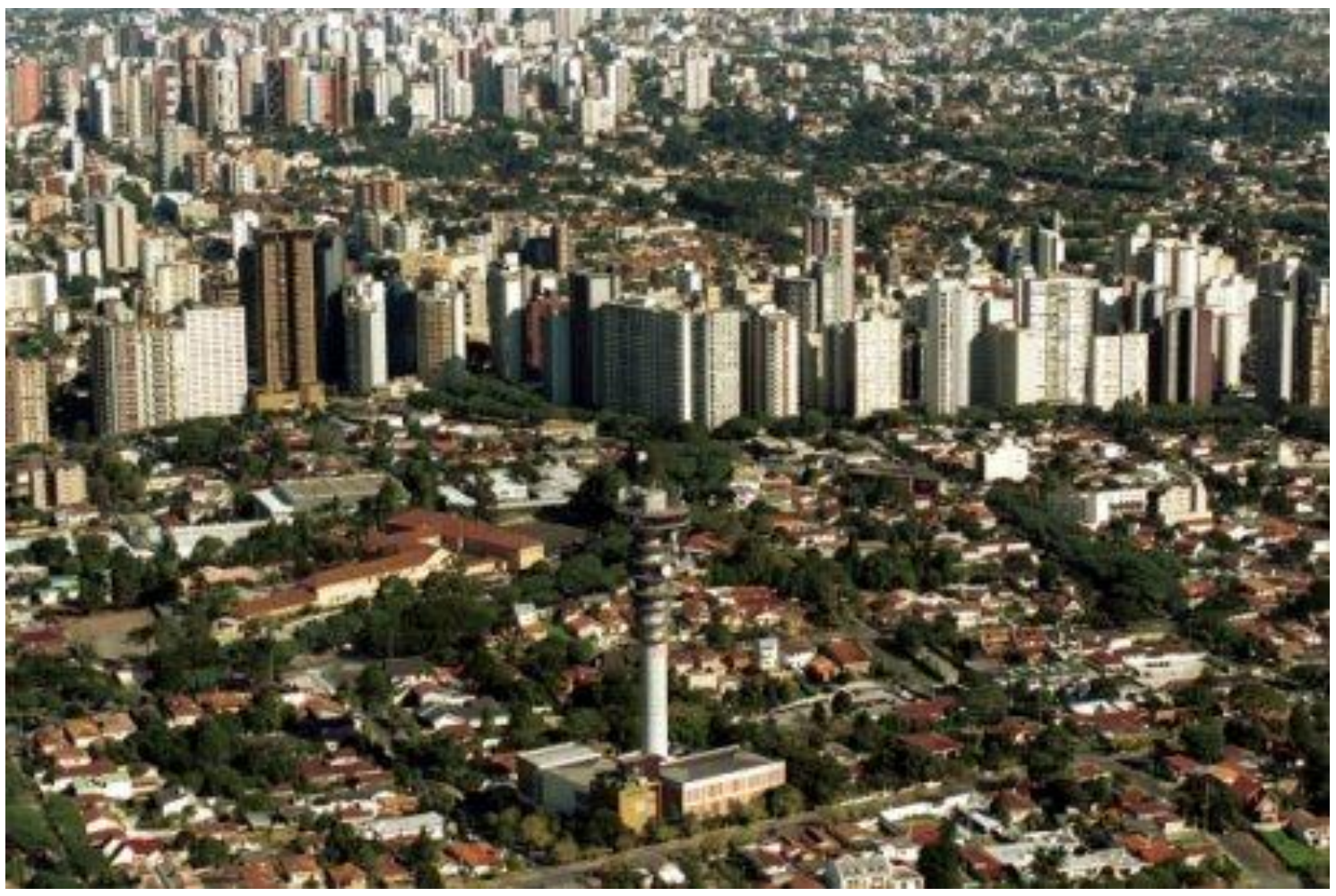

Figura 2-1 - Foto aérea de Curitiba

Fonte: http://www.curitiba.pr.gov.br/

Bogotá, capital da Colômbia, enfrentou graves problemas com relação ao transporte público até implantar um sistema de transporte de massa denominado TransMilênio, que juntamente com seu sistema coletor, formado por ônibus, mudou a cidade e a lógica de usos do solo (Parras, 2006).

A Figura 2-2 mostra o desenvolvimento da cidade após a instalação do sistema TransMilênio. 


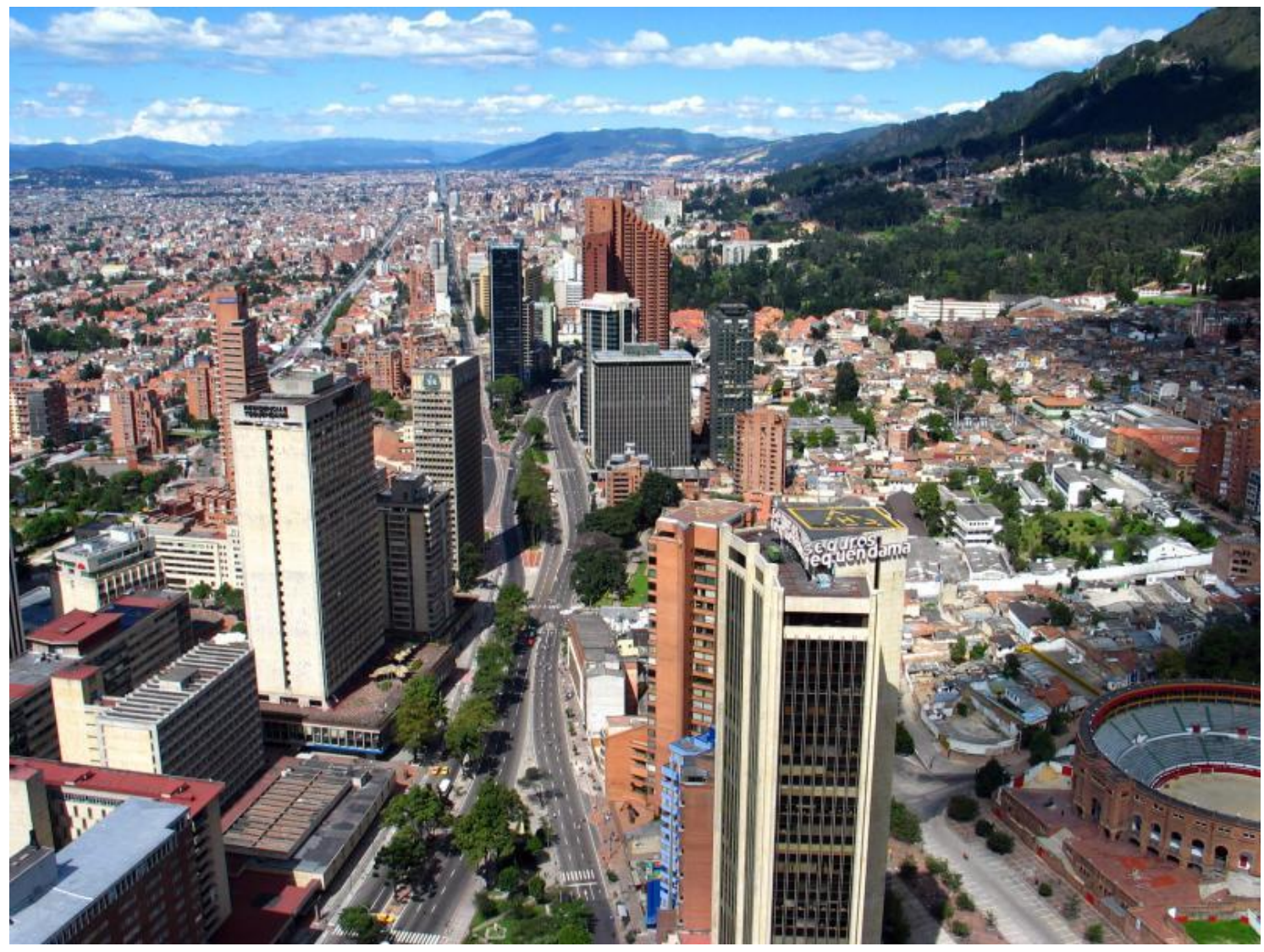

Figura 2-2 - Foto aérea de Bogotá

Fonte: http://www.viagemfacil.com.br/1014/bogota-colombia

Nos Estados Unidos existem diversas cidades que aplicaram as bases do TOD em seus projetos, mas os exemplos citados das cidades latino-americanas mostram que essa nova forma de pensar o urbanismo não está associada unicamente ao modo estadunidense de construir cidades.

Maiores informações sobre TOD podem ser encontradas nos artigos contidos no site http://www.transitorienteddevelopment.org.

\subsection{Geração de viagens}

Para compreender o desenvolvimento de uma determinada região e sua relação com a demanda por transportes se faz necessário esclarecer alguns conceitos relacionados à geração das viagens e como se dá a influência do uso do solo sobre elas.

Quando uma região possui uma predominância residencial, ela, do ponto de vista dos transportes, é considerada produtora de viagens. Isso significa que uma viagem surge da necessidade de um indivíduo sair de sua base, a residência, para 
realizar atividades.

Disto resulta que demais usos do solo, sejam eles comércios, serviços ou indústrias, são locais de atração de viagem, pois neles estão contidas as atividades que os indivíduos desejam realizar, ou seja, os motivos pelos quais eles decidem realizar viagens.

Ressalta-se, no entanto, a diferença existente entre os conceitos de produção e atração de viagens e os conceitos de origem e destino.

Enquanto uma viagem que possua a residência como um dos extremos tem sua origem no local em que se inicia a viagem e seu destino no seu local de término, considera-se que sua produção ocorre na residência, sendo, então, atraída para o local da atividade escolhida pelo indivíduo, mesmo que a viagem em questão seja de retorno para casa. Ou seja, na situação de retorno do trabalho para casa, o trabalho seria a origem e o local de atração, enquanto a residência seria o destino e o local de produção da viagem.

Uma explicação mais aprofundada desses conceitos pode ser encontrada no livro de Ortuzar e Willumsen (2010).

\subsection{Conceitos de acessibilidade e mobilidade}

Para se estabelecer uma base conceitual definem-se aqui os conceitos de acessibilidade e mobilidade, destacando suas diferenças.

Uma definição intuitiva de acessibilidade é a facilidade com a qual se pode acessar oportunidades distribuídas no espaço. É a facilidade com a qual conseguimos realizar viagens para alcançar os locais de trabalho, os equipamentos de educação, saúde e lazer e, evidentemente, voltar para casa (Deak, 2004). Portanto, ressalta-se que acessibilidade é um atributo do território.

Medidas de acessibilidade contêm tanto um fator de impedância (que reflete o tempo e/ou o custo de se atingir um destino) como um fator que expressa a atratividade do destino. Ao depender simultaneamente da distribuição geográfica das oportunidades desejadas e da disponibilidade de serviços de transporte, o conceito de acessibilidade estabelece uma relação entre transportes e uso do solo 
(Handy, 2002).

Já mobilidade se refere à capacidade de se movimentar. Recentemente se constata um deslocamento das medidas focadas no aumento dos índices de mobilidade, que dizem mais respeito à capacidade do usuário de se deslocar que à qualidade do espaço em que ele se desloca, para as medidas promotoras de melhor acessibilidade no espaço urbano. Mobilidade, portanto, é um atributo das pessoas (Handy, 2002).

Esses dois itens são, portanto, complementares, e enquanto melhorias no sistema de transportes influem na acessibilidade do entorno de onde é implantado um sistema de transportes, melhorias sociais e econômicas permitem melhorias na mobilidade dos usuários desse sistema.

Com esses conceitos apresentados, pode-se tratar da influência que acessibilidade tem sobre o uso do solo, assim como do aumento da mobilidade dos residentes neste entorno.

\subsection{Valorização do solo devido à melhoria na acessibilidade}

Ao longo do tempo, as cidades brasileiras cresceram organizadas de forma a privilegiar uma lógica mercadológica na qual se concentram atividades nobres em áreas mais valorizadas, com melhores condições infraestrutura, como saneamento e acessibilidade, e com menos poluição. Estas áreas acabam por abrigar as classes mais abastadas e as classes mais baixas são afastadas para regiões de menor interesse do mercado imobiliário.

Essa configuração de cidade é produzida pelas classes de mais alta renda, com a manutenção de sua localização na cidade em eixos viários que facilitem o acesso ao Centro - aqueles que elas produzem para si - como forma de garantir a dominação social e política (Villaça, 2012).

Este arranjo traz maior necessidade de transporte tanto das classes mais abastadas, usualmente através do modo individual privado, quanto das classes menos privilegiadas, que priorizam o modo coletivo público se este existir e permitir a locomoção para os locais de desejo dessa população. 
Segundo Deak (1985), no capitalismo, o mercado unificado requer que seu espaço seja suficientemente homogeneizado por uma infraestrutura de transporte e comunicações. No entanto, o desenvolvimento dos meios de transporte e infraestrutura libera a localização da produção de estar próxima da matéria-prima e fontes de energia, permitindo a concentração da produção e da força de trabalho. Isto gera urbanização e cria uma nova diferenciação do espaço. Assim, homogeneidade e diferenciação do espaço se moldam incessantemente pela intervenção do capital e do trabalho.

De maneira análoga, a densidade populacional e necessidade de melhorias de acessibilidade levam à construção de infraestruturas, o que, por sua vez, causa valorização e mudanças de uso do solo, assim como necessidade de novas melhorias.

Essas mudanças de uso do solo e densidade causam uma mudança de valor da terra, descrita por Deak (1985) como Localização, sendo definida como um valor de uso para toda atividade de produção. Ela é uma condição necessária para o desempenho de qualquer atividade, pois toda atividade precisa ocupar uma posição no espaço urbano para se desenvolver. O pagamento pela localização entra no preço de produção de mercadorias e regula a distribuição dessas mercadoria no espaço urbano. A melhor distribuição da produção implica na melhor organização espacial, refletindo na valorização da localização.

Em seu estudo, Nigriello (1977) avalia a valorização que a mudança de acessibilidade propiciou no trecho sul da linha Azul do Metrô. Macêdo (2010) realizou um estudo imobiliário para regiões que também receberam estações de Metrô, demonstrando que o mercado imobiliário percebe esse valor associado à construção de estações de Metrô e volta seus investimentos para essas regiões.

Essa melhoria de acessibilidade causa a sensação de proximidade, com o efeito do tempo ganhando força e dominando o efeito da distância. De acordo com Zmitrowicz (1997), o mundo tem a capacidade de se deformar na medida em que se permitem acessibilidades diversas das existentes, refletindo em mudanças econômicas sobre as propriedades territoriais. Assim sendo, locais que ganhem o benefício de uma estrutura que aumente a velocidade dos fluxos, tornam-se ideais 
para o adensamento e surgimento de novas atividades.

Efetivamente, um bairro que estivesse a quarenta minutos do centro, mas que permitisse que um indivíduo chegasse ao centro em vinte minutos com a implantação de um novo meio de transporte teria sua percepção de proximidade modificada. Este fator é algo valorizado pelo usuário, que passará a tratar esta região com a mesma importância, mesmo valor, que uma região semelhante com relação a outros fatores que diste reais vinte minutos, e o mercado torna isso mensurável no valor do solo.

Disto resulta que os extremos das linhas de Metrô exibem, em relação aos outros pontos, a maior valorização, pois elas observarão a maior redução de tempo, a maior aproximação das oportunidades (Nigriello, 1977). No entanto, o estudo de Guimarães (2011), voltado para a futura Linha 6, do metrô de São Paulo, indica que, mesmo tendo a maior valorização, os extremos de uma linha perdem em competitividade para os outros pontos da mesma linha. Os resultados desses dois estudos não se contradizem, pois os extremos da Linha 1 - Azul possuíam um baixo valor e tiveram a maior valorização, no entanto regiões mais próximas do centro pertencentes à mesma linha, que tiveram uma valorização menor, continuaram mais valorizadas, como a região da Vila Mariana, no caso residencial, ou Paraíso, no caso de serviços e comércio. O mesmo é esperado para a futura Linha 6, que apresentaria uma grande valorização em seu extremo Brasilândia atualmente desconectado da rede metroviária, porém teria uma atratividade menor que outras regiões da linha mais próximas do trecho conectado.

Um transporte que seja feito de maneira mais rápida, economizando o tempo do usuário, permite que seu raio de deslocamento no espaço aumente, assim como permite que ele utilize mais de seu tempo para as atividades que deseja realizar.

No caso da inserção de uma estação de Metrô em uma localidade, esse efeito de valorização em função do ganho temporal percebido se explica quando se analisa a população que utiliza o benefício do transporte diretamente como usuários da nova estação, mas surge a dúvida de como o valor se difunde para os habitantes que não farão uso do transporte público.

Segundo Nigriello (1987), existe uma relação de causalidade na área urbana, 
de modo que a inserção de uma estrutura do porte de uma estação de Metrô consegue ser influente na transformação espacial das atividades urbanas e na valorização dos imóveis que constituem seu entorno.

Assim, o aumento de acessibilidade provoca interesse de parte da população, de lojistas e fornecedores de serviços, que incentivam uma mudança no entorno e a inserção desses novos locais de comércio e serviços auxiliam na valorização.

Entretanto, o mercado imobiliário, tendo a percepção dessa valorização, inicia a modificação do entorno e aumento no valor do solo antes mesmo do término da construção da infraestrutura de transportes.

No fim, a valorização associada à construção da estação é sentida ao longo da linha proporcionalmente à melhoria de acessibilidade aos centros comerciais e de serviços, locais de empregos, compras, saúde e lazer.

\subsection{Os riscos de exclusão social causada pelos transportes}

A literatura que explora as interfaces entre exclusão social e transportes é bem recente. Um estudo do governo britânico (Social Exclusion Unit, 2003) é considerado, nesse sentido, um marco ao constatar que certos grupos são socialmente excluídos por estarem privados de usufruir determinadas oportunidades. $\mathrm{O}$ documento sublinha a importância de implementar estratégias de planejamento com foco no aumento da acessibilidade. Dessa forma, as autoridades britânicas reconhecem a acessibilidade como um meio de promover a inclusão social. Este estudo inglês demonstra que a valorização causada pelo aumento de acessibilidade pode resultar na "expulsão" dos moradores anteriores à intervenção, que não podem arcar com o novo custo de vida na localidade.

Nigriello (1977) tece diversas considerações com relação à capacidade de transformar socialmente o entorno de investimentos de transportes do porte do Metrô. Enquanto alguns acreditam que ele seja capaz de promover redistribuição de renda, para outros o efeito oposto é que ocorre.

Diversos agentes sociais influem na definição da remodelação do entorno de um equipamento deste porte. Correia (1999) define cinco agentes sociais: 
proprietários dos meios de produção, proprietários fundiários, Estado, promotores imobiliários e excluídos sociais.

O Estado possui instrumentos para atuar na remodelação desse espaço urbano, como a regulamentação do uso do solo, controle, impostos fundiários e imobiliários, produção do espaço através da provisão de novas infraestruturas.

Os promotores imobiliários, quando não bem regulados pelo Estado, agem de maneira a obter a utilidade mais rentável para a região em que desempenham mudanças.

Os proprietários de meios de produção e os proprietários fundiários detém certo poder de barganha com o Estado e certa influência sobre os promotores imobiliários, pois são eles que detêm em suas mãos o capital.

Os excluídos sociais fazem parte de um processo complexo associado a vários fatores, sendo impossível rotular alguém como "excluído" com base em um único critério, pois a exclusão social refere-se a uma combinação de privações que envolvem os campos do trabalho, educação, renda, moradia, saúde e estrutura familiar (Guimarães, 2011).

Conhecendo esses agentes, pode-se falar de uma das mudanças que pode ocorrer no entorno de uma nova infraestrutura de transportes caso o Estado não intervenha - a substituição populacional. Este processo, chamado gentrificação (Mosqueira, 2007), uma expressão consagrada no urbanismo e planejamento urbano, é caracterizado pelo enobrecimento de espaços urbanos que sofrem intervenções, levando à valorização imobiliária e encarecimento do custo de vida na região, o que resulta em "expulsão" dos moradores anteriores à intervenção, e a substituição por uma nova população que é capaz de arcar com o com este custo.

Este processo não é o único que ocorre ao redor de estações, sendo também observada, quando permitida pela lei de uso do solo, a substituição de residências por serviços e comércios, que buscam se beneficiar da acessibilidade aumentada pela nova estação.

A lei Federal n5.519 (29 de dezembro de 1988) de contribuição de melhorias propiciou campo para diversas ações que visassem aplicar tributação nos imóveis 
valorizados pela infraestrutura instalada em uma região. Existe no Plano Diretor da RMSP uma previsão de divisão de receita advinda de outorga onerosa do direito de construir em áreas de influência do metrô, permitindo financiar novas linhas que beneficiem outras regiões. Esta lei, no entanto, entende como beneficiários da infraestrutura somente aqueles próximos a ela, não dividindo o ônus da construção com o restante da cidade, também beneficiário do sistema como um todo.

Apesar de a lógica legislativa implicar que os cidadãos beneficiados por um novo sistema de transporte devam ressarcir este benefício, as políticas públicas precisam ser orientadas àqueles que não teriam capacidade de fazê-lo. Eles acabam vendo benefício maior em se mudar para um local mais distante, vendendo o imóvel e dando lugar a famílias que podem pagar pelos benefícios da proximidade a uma estação. Esta venda normalmente não se reflete na simples substituição de moradores, mas na construção de edifícios maiores utilizando conjuntos de terrenos vizinhos, como abordado por Macêdo (2010). Assim, o tempo ganho com a melhora na acessibilidade é revertido em mais valia na venda dos imóveis e os novos locais de moradia da população que sair da região provavelmente estarão a uma distância em que o tempo de viagem seja igual - ou superior - ao anterior.

A proximidade da estação nem sempre provoca as mudanças esperadas, pois muitas vezes as famílias que se mudam para perto do metrô não usam o transporte coletivo, tendo se mudado para a região simplesmente porque havia disponibilidade de novos imóveis do padrão desejado a preços que condizem com suas possibilidades e desejam essa região melhor qualificada, como será visto durante esse estudo.

Portanto atenta-se para a necessidade de planejar a inserção de um elemento de transportes levando em consideração o benefício que está sendo concedido ao se melhorar a acessibilidade de uma determinada região, avaliando-se os ganhos para as áreas próximas às estações, para a linha como um todo e, finalmente, para a cidade. 


\section{Estudos relacionados}

Este capítulo reuniu alguns estudos sobre o comportamento da demanda por viagem associado ao ambiente construído e mudanças no entorno de estações de transportes.

Ele será dividido em casos fora do Brasil, obtendo diretrizes mais gerais sobre o tema; casos no Brasil, permitindo inserções na realidade brasileira; e finalmente casos em São Paulo, cuja proximidade com o estudo permitirá obter conclusões e premissas para esta dissertação.

\subsection{Estudo de casos no Exterior}

Ewing e Cervero (2010) compilaram diversos estudos nos Estados Unidos, relacionando comportamento da demanda por viagem associado ao ambiente construído e características socioeconômicas, utilizando medidas de "elasticidade" para estabelecer essas relações.

Usando dados de viagens diárias de Nova York e New Jersey, Salon (2006) conclui que um ambiente construído compacto e com diversidade de usos contribui com cerca de 1/2 a 2/3 da diferença de viagens a pé associados com mudanças na densidade populacional na maioria das áreas de Nova York.

Apesar de não poder ser diretamente utilizado, este resultado aponta para a importância de se relacionar mudanças nos padrões de viagem a mudanças de uso do solo e características socioeconômicas.

Zhou e Kockelman (2008), em um estudo em Austin, Texas, concluíram que o ambiente construído contribuiu com $58 \%$ a $90 \%$ da influência total na escolha da localização residencial. Este estudo foca a relação entre a escolha de onde residir e sua dependência do ambiente construído. Assim, a escolha da residência parece ter uma relação muito forte com as atividades que o indivíduo pretende realizar, escolhendo um entorno favorável a essas atividades ou que tenha acesso facilitado a elas.

Com dados de viagem de quatro regiões de configuração suburbana no Estado 
da Carolina do Norte, Cao (2010) reportou que, na média, o tipo de vizinhança contribuiu com $6 \%$ do efeito observado na frequência das viagens a pé úteis e $86 \%$ das viagens a pé de lazer.

Das conclusões deste estudo, percebe-se o quanto um ambiente construído com enfoque no pedestre e na proximidade de atividades pode influenciar nas viagens a pé, mostrando que a escolha modal é influenciada fortemente pela forma como a cidade se consolida.

Ewing e Cervero (2001) sustentam que a frequência de viagem, a escolha de modo e os comprimentos de viagem são funções das características socioeconômicas dos usuários e do ambiente construído, assim sendo, estudar mudanças no comportamento da demanda por viagem de uma determinada região consiste em encontrar nas características socioeconômicas e no uso do solo a explicação para as mudanças observadas.

Assim, dos estudos no exterior citados, pode-se agregar o conhecimento de que para analisar o comportamento da demanda por viagem é necessário avaliar as características socioeconômicas e o ambiente construído da região de estudo.

\subsection{Estudo de casos no Brasil}

Entre os estudos de caso no Brasil, dois foram selecionados por tratar de casos semelhantes ao desta dissertação: alterações no entorno devido à inserção de um sistema de transportes.

O estudo realizado em Samambaia, cidade da Região Metropolitana de Brasília, relata que em 1997, antes da inserção das estações do metrô, o padrão de uso do solo era uniforme na área de estudo. Com o crescimento da cidade, em 2007 percebeu-se que os caminhos a pé até estação final coincidiam com os locais de adensamento, mostrando esses caminhos como vetores de crescimento urbano (Takano, Silva e Taco, 2009). Este estudo, já com uma realidade mais próxima da paulistana, relaciona o vetor de crescimento da cidade à localização espacial dos acessos realizados a pé até as estações do Metrô em Samambaia, indicando que a possibilidade de locomoção a pé até este equipamento favoreceria a escolha de localização de residências, comércios e serviços. 
O estudo de Andrade e Maia (2009) para a Linha 1 do Metrô de Recife, no entanto, sinaliza na direção contrária, apontando não ter havido valorização ou crescimento populacional na região de entorno do Metrô. Os autores do estudo, no entanto, justificam o resultado, inesperado para eles, dizendo que a localização sobre a antiga ferrovia provavelmente manteve a lógica segregatória anterior.

\subsection{Estudo de casos em São Paulo}

Finalmente, uma compilação de estudos realizados em São Paulo, alguns, inclusive tratando também das mesmas localidades do presente estudo, permite adotar certas premissas e baliza o prosseguimento dos trabalhos.

Em seu estudo sobre a Linha 1 - Azul do Metrô de São Paulo, Nigriello (1977) avalia a valorização que o mercado imobiliário realizou na região de entorno das estações, aferindo sua valorização, e constatando que os extremos norte (à época a estação Santana) e sul (Jabaquara) tiveram a maior valorização percentual.

Cabe ressaltar que essa valorização percentual não garante desenvolvimento às regiões mais distantes atendidas pelo metrô. Segundo constatações de Guimarães (2011), em estudo sobre a futura Linha 6 - Laranja, quase todos os bairros atendidos pelo metrô apresentam níveis de acessibilidade bastante elevados. Ele destaca que a entrada em operação da linha, que irá de Brasilândia (na região noroeste da cidade) a São Joaquim (na porção sul da região central), não deve alterar substancialmente a situação de desigualdade de acessibilidade atualmente em vigor. No cenário futuro, com a linha em operação, mesmo moradores da região noroeste da cidade deverão ter níveis de acessibilidade ao trabalho inferiores aos de residentes de regiões centrais. Uma área contínua que se estende da Liberdade até a Pompéia registra variações positivas no índice de acessibilidade. No entanto, diversas regiões que não se encontram ao longo do eixo da linha planejada (principalmente no sul e no sudoeste da cidade de São Paulo) também apresentam substanciais ganhos de acessibilidade. Este resultado sugere que residentes de bairros próximos às linhas existentes de metrô sejam beneficiados com a expansão da rede. Por outro lado, algumas zonas diretamente servidas pela Linha 6 podem ter a acessibilidade a postos de trabalho reduzida em relação a outras zonas mais centrais, apesar do novo serviço de transporte coletivo. 
Estes estudos, no entanto, não se contradizem, pois o primeiro trata da valorização territorial e apenas retrata o ganho ocorrido. Já o segundo trata do ganho de acessibilidade, esclarecendo que, mesmo havendo ganhos para o extremo noroeste da linha (Brasilândia), outras áreas possuem um ganho maior, e em uma análise de favorecimento, outras regiões acabariam, inclusive, por tomar oportunidades de emprego.

Segundo um estudo sobre empreendimentos imobiliários no entorno de estações de Metrô de São Paulo (Macêdo, 2010), o aumento de empreendimentos é fortemente sentido nessa áreas, com residências de padrão mais elevado que o anterior, ocupando mais área. Além disso, ocorre o surgimento de comércios e serviços. Destes dois tipos de eventos resulta uma possível redução populacional.

Outro estudo sobre a evolução da estrutura da metrópole entre 1997 e 2007 (Passos, 2011) trata de diversas regiões da cidade, criando uma categorização entre zonas polarizadoras (atratoras de viagem) e residenciais (produtoras de viagem).

A autora comenta que a expansão da área polarizadora do centro metropolitano é relativamente muito maior e mais intensa do que o crescimento e desenvolvimento dos "polos" autônomos. A O/D2007 registra um aumento do número de zonas lindeiras ao Metrô classificadas por ela como polarizadoras.

Foram selecionadas algumas conclusões do estudo de Passos (2011) sobre as zonas estudadas nesta dissertação. A zona Jardim São Paulo era considerada residencial em 1997 e passa para polarizadora em 2007, enquanto a Santana ganha força polarizadora em 2007. Em 2007 se verifica a intensificação da polarização na direção oeste. A área lindeira ao sul da Marginal Pinheiros também apresenta crescimento da polarização, nas zonas Vila Leopoldina, Emissário e Ceasa. No extremo oeste da Linha 2 do Metrô verifica-se uma zona onde o crescimento da densidade residencial em Perdizes. Sumaré deixa de ser uma zona residencial e passa à categoria polarizadora.

Como conclui a autora, a indução da ocupação exercida pela implantação do Metrô foi aprofundada entre 1997 e 2007, mostrando o significado que a rede metroviária está adquirindo no espaço urbano de São Paulo. De fato, a relevância deste estudo para o presente trabalho é a de mostrar que as zonas da O/D2007 
relacionadas a estações de Metro ganharam polarização, ou seja, tornam-se mais atratoras de viagem.

Vale lembrar que a rede de Metrô de São Paulo é extremamente reduzida quando comparada a qualquer outra metrópole do mundo. Segundo Deák (1990), ela parece altamente "eficiente" em número de passageiros transportados por quilômetro de linha, porém esse índice é fruto das frequências altas das composições e da taxa de ocupação, que levam a uma operação próxima à capacidade de saturação. Somente a alta frequência atesta realmente eficiência, enquanto a taxa de ocupação elevada ressalta a demanda reprimida. Para ele, um melhor indicativo do nível de atendimento seria quilômetro de linha por habitante, índice no qual São Paulo ficaria com o contra-recorde absoluto entre as capitais mundiais.

O fato da rede reduzida pode ter uma influência grande tanto na polarização quanto na valorização das zonas próximas ao Metrô, pois sendo um recurso escasso, torna-se um diferencial de infraestrutura. 


\section{Metodologia}

Este capítulo trata da metodologia utilizada na dissertação.

Para a realização deste estudo foram observadas as diferenças nas características das viagens e socioeconômicas anterior e posteriormente à implantação das estações nas zonas de entorno. Essas mudanças foram comparadas àquelas ocorridas em zonas próximas das zonas de entorno, mas que não receberam este equipamento. Este segundo grupo de zonas serviu como controle das modificações ocorridas na região, uma vez que a influência do Metrô neste grupo de controle se deu de maneira indireta.

É também importante observar o que aconteceu com as características analisadas para a Região Metropolitana de São Paulo (RMSP) como um todo, capturando também os efeitos comuns a toda a metrópole paulistana.

Para a realização desta análise as pesquisas de Origem e Destino de 1997 e 2007 (a primeira, anterior à instalação das estações e, a segunda, posterior) permitem uma análise das características de viagens nessas zonas em ambos os anos de pesquisa.

Ressalta-se que a implantação das estações ocorreu em 1998 havendo separação temporal suficiente até 2007 - ano da segunda pesquisa utilizada - para observar seu impacto.

\subsection{Delimitação das zonas de estudo}

Para realizar a análise das regiões de entorno dos prolongamentos das linhas 1 - Azul e 2 - Verde foi utilizado o zoneamento adotado para a pesquisa Origem e Destino 1997. Este zoneamento possui 389 zonas e uma relação com o zoneamento realizado em 2007, que possui 460 zonas. A diferença se dá por desagregações realizadas de 1997 para 2007, ou seja, as zonas de 2007 que não se mantiveram coincidentes com as de 1997 são apenas resultado de divisões das zonas da pesquisa anterior, como exemplificado na Figura 4-1.

Os dados deste estudo foram obtidos das O/Ds 1997 e 2007. Assim, a fonte 
para todas as tabelas e gráficos utilizados são dados dessas duas pesquisas.

Foram analisados neste estudo os entornos das estações Parada Inglesa, Jardim São Paulo e Tucuruvi, da Linha 1 - Azul, e das estações Sumaré e Vila Madalena, da Linha 2 - Verde, que entraram todas em operação no ano de 1998, no intervalo entre as pesquisas O/D utilizadas.

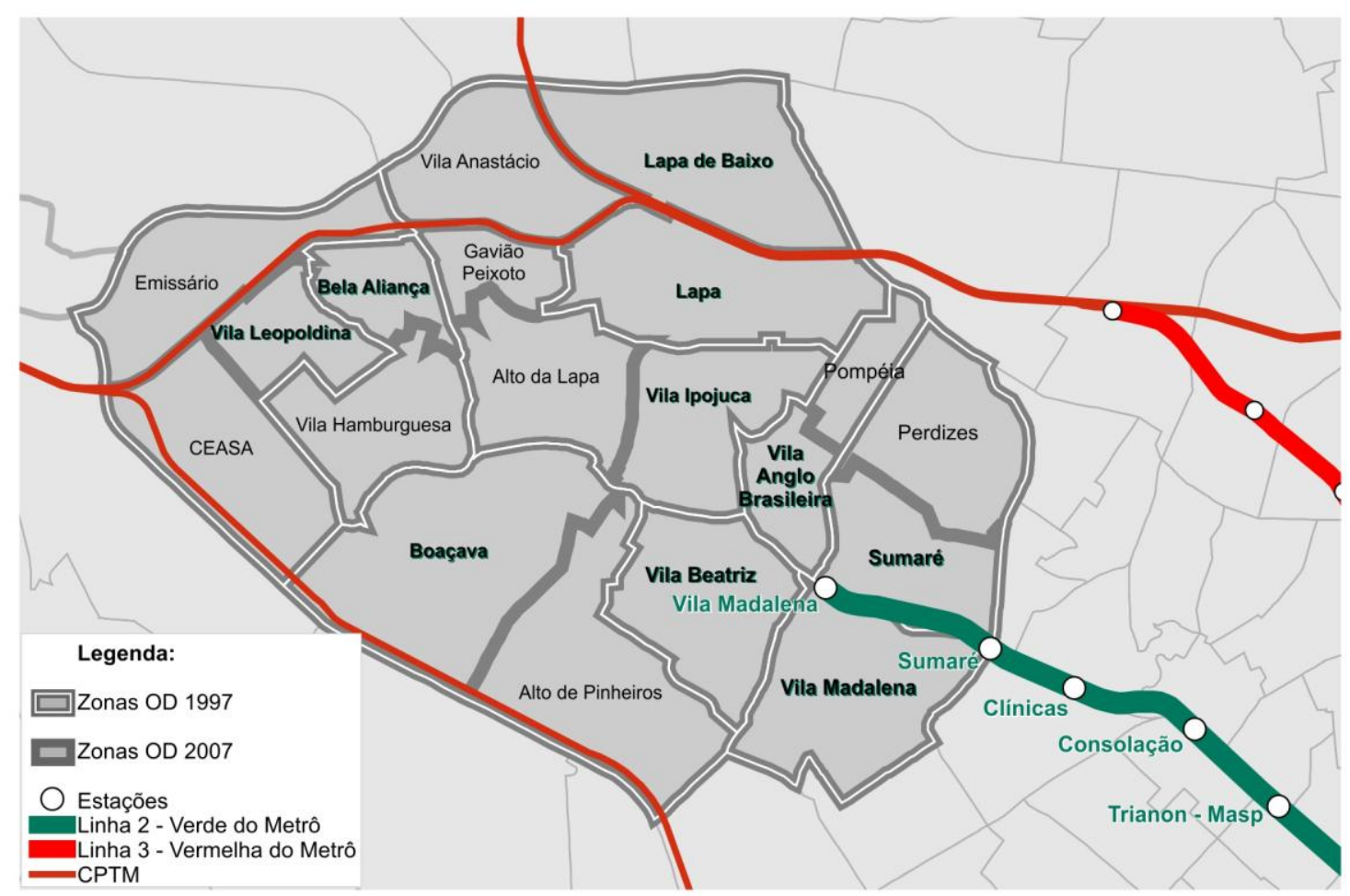

Figura 4-1 - Relação entre o zoneamento da O/D1997 e O/D2007

As zonas do entorno da Linha 1 - Azul não apresentaram divergência entre os zoneamentos de 1997 e 2007. As zonas do entorno da Linha 2 - Verde, que foram divididas no zoneamento de 2007, tiveram suas informações agregadas novamente nas zonas de 1997 para permitir a análise, como mostra a Figura 4-1.

Optou-se por selecionar as zonas para o estudo em um arco a partir da última estação anterior à extensão, buscando-se evitar zonas que já estivessem atendidas anteriormente pelo Metrô.

Foram selecionadas para o estudo grupos de zonas no entorno das duas extensões de linha, candidatas ao grupo que sofre influência direta do Metrô. Foram selecionadas também algumas zonas mais distantes, mas adjacentes ao primeiro grupo, como candidatas ao grupo de controle. 
Foram estimadas as viagens realizadas pelo modo coletivo para cada uma das zonas, sendo consideradas as viagens com origem ou destino nas zonas selecionadas. Estas viagens pelo modo coletivo foram classificadas em:

- Acesso direto ao Metrô - considerando o Metrô como primeiro modo utilizado quando a zona de estudo é origem da viagem, bem como último modo quando a zona de estudo é o destino da viagem;

- Outros modos + Metrô - considerando o Metrô não sendo o primeiro modo utilizado quando a zona de estudo é origem da viagem, bem como não sendo o último modo quando a zona de estudo é o destino da viagem;

- Somente combinações de outros modos.

Notou-se que as zonas candidatas do entorno imediato das estações apresentarammais de $7 \%$ das viagens estimadas dentro da classificação "Acesso direto ao Metrô" em 2007, enquanto as outras apresentavam no máximo 3\%.

Adotou-se, então, como critério para a classificação "Acesso direto ao Metrô" zonas que apresentassem no mínimo 7\% de viagens do modo coletivo com acesso direto ao extremo na zona pelo Metrô, garantindo separação razoável entre o percentual das candidatas do entorno e das mais distantes.

A Tabela 4-1 e a Tabela 4-2 apresentam, para cada zona, os percentuais estimados de viagens pela classificação "Acesso direto ao Metrô" dentre as viagens pelo modo coletivo para as linhas 1 - Azul e 2 - Verde, respectivamente, assim como as quantidades de viagens na amostra, entre parênteses.

Formaram-se os grupos:

- Grupo com Metrô - zonas que apresentam 7\% ou mais das viagens do modo coletivo classificadas como Acesso direto ao Metrô em 2007;

- Grupo sem Metrô - zonas próximas ao primeiro grupo que não atingiram $7 \%$ de viagens classificadas como Acesso direto ao Metrô em 2007;

- RMSP - universo das pesquisas O/D, incluindo os grupos anteriores. 
Tabela 4-1. Zonas selecionadas para o estudo no entorno da Linha 1 - Azul

\begin{tabular}{|c|c|c|c|c|c|}
\hline \multirow[b]{3}{*}{ Grupo } & \multirow[b]{3}{*}{ Zona } & \multicolumn{4}{|c|}{ Acesso direto ao Metrô } \\
\hline & & \multicolumn{2}{|c|}{1997} & \multicolumn{2}{|c|}{2007} \\
\hline & & Estimado & Amostral & Estimado & Amostral \\
\hline \multirow{5}{*}{ 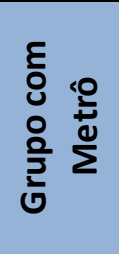 } & Isolina Mazzei & $4 \%$ & $(16 / 297)$ & $7 \%$ & $(29 / 268)$ \\
\hline & Jd. São Paulo & $5 \%$ & $(18 / 203)$ & $28 \%$ & $(97 / 288)$ \\
\hline & Parada Inglesa & $1 \%$ & $(2 / 143)$ & $36 \%$ & $(77 / 189)$ \\
\hline & Tucuruvi & $2 \%$ & $(3 / 150)$ & $9 \%$ & $(19 / 193)$ \\
\hline & Vila Gustavo & $1 \%$ & $(1 / 237)$ & $14 \%$ & $(29 / 173)$ \\
\hline \multirow{13}{*}{ 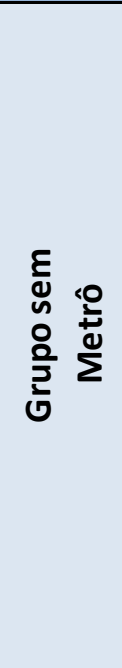 } & Vila Medeiros & $2 \%$ & $(4 / 168)$ & $3 \%$ & $(3 / 117)$ \\
\hline & Pq. Edu Chaves & $0 \%$ & $(0 / 80)$ & $0 \%$ & $(0 / 134)$ \\
\hline & Vila Terezinha & $0 \%$ & $(1 / 372)$ & $0 \%$ & $(0 / 135)$ \\
\hline & Cachoeirinha & $4 \%$ & $(4 / 261)$ & $0 \%$ & $(1 / 223)$ \\
\hline & Jardim Peri & $2 \%$ & $(2 / 159)$ & $1 \%$ & $(1 / 119)$ \\
\hline & Mandaqui & $8 \%$ & $(27 / 299)$ & $1 \%$ & $(2 / 207)$ \\
\hline & Horto Florestal & $0 \%$ & $(0 / 105)$ & $0 \%$ & $(0 / 101)$ \\
\hline & Tremembé & $0 \%$ & $(0 / 101)$ & $2 \%$ & $(6 / 197)$ \\
\hline & P. do Tremembé & $0 \%$ & $(0 / 103)$ & $0 \%$ & $(0 / 113)$ \\
\hline & Jaçanã & $0 \%$ & $(3 / 173)$ & $1 \%$ & $(7 / 171)$ \\
\hline & Jardim Guapira & $1 \%$ & $(2 / 268)$ & $3 \%$ & $(9 / 168)$ \\
\hline & Cohab Jova Real & $0 \%$ & $(0 / 70)$ & $1 \%$ & $(1 / 115)$ \\
\hline & Jd. Damasceno & $0 \%$ & (0/199) & $1 \%$ & $(1 / 121)$ \\
\hline
\end{tabular}

( )Viagens na amostra com Acesso direto ao Metrô/ viagens na amostra pelo modo coletivo

Tabela 4-2. Zonas selecionadas para o estudo no entorno da Linha 2 - Verde

\begin{tabular}{|c|c|c|c|c|c|}
\hline \multirow[b]{3}{*}{ Grupo } & \multirow[b]{3}{*}{ Zona } & \multicolumn{4}{|c|}{ Acesso direto ao Metrô } \\
\hline & & \multicolumn{2}{|c|}{1997} & \multicolumn{2}{|c|}{2007} \\
\hline & & Estimado & Amostral & Estimado & Amostral \\
\hline \multirow{4}{*}{ 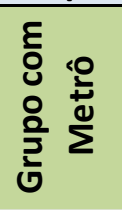 } & Vila Madalena & $13 \%$ & $(17 / 170)$ & $27 \%$ & $(97 / 327)$ \\
\hline & Sumaré* & $5 \%$ & $(17 / 387)$ & $13 \%$ & $(93 / 455)$ \\
\hline & Vila Anglo Brasileira* & $4 \%$ & $(6 / 122)$ & $12 \%$ & $(64 / 360)$ \\
\hline & Vila Beatriz & $0 \%$ & $(0 / 99)$ & $27 \%$ & $(53 / 217)$ \\
\hline \multirow{6}{*}{ 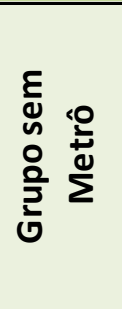 } & Lapa & $0 \%$ & $(7 / 701)$ & $1 \%$ & $(9 / 719)$ \\
\hline & Vila Ipojuca* & $1 \%$ & $(3 / 254)$ & $3 \%$ & $(14 / 569)$ \\
\hline & Lapa de Baixo* & $1 \%$ & $(3 / 239)$ & $3 \%$ & $(13 / 470)$ \\
\hline & \begin{tabular}{|l|} 
Boaçava* \\
\end{tabular} & $4 \%$ & $(2 / 94)$ & $2 \%$ & $(6 / 408)$ \\
\hline & Bela Aliança* & $0 \%$ & $(0 / 122)$ & $0 \%$ & $(3 / 353)$ \\
\hline & Vila Leopoldina* & $0 \%$ & $(1 / 251)$ & $2 \%$ & $(11 / 671)$ \\
\hline
\end{tabular}

*Agregado para o zoneamento da O/D97

( )Viagens na amostra com Acesso direto ao Metrô/ viagens na amostra pelo modo coletivo

Cabe ressaltar o aumento percentual dos acessos diretos ao Metrô entre 1997 e 2007 para as zonas consideradas no Grupo com Metrô. Nas zonas do Grupo sem Metrô, esse aumento não é representativo. 
A Figura 4-2 mostra a divisão dos grupos para a Linha 1 - Azul e a Figura 4-3 mostra essa divisão para a Linha 2 - Verde.

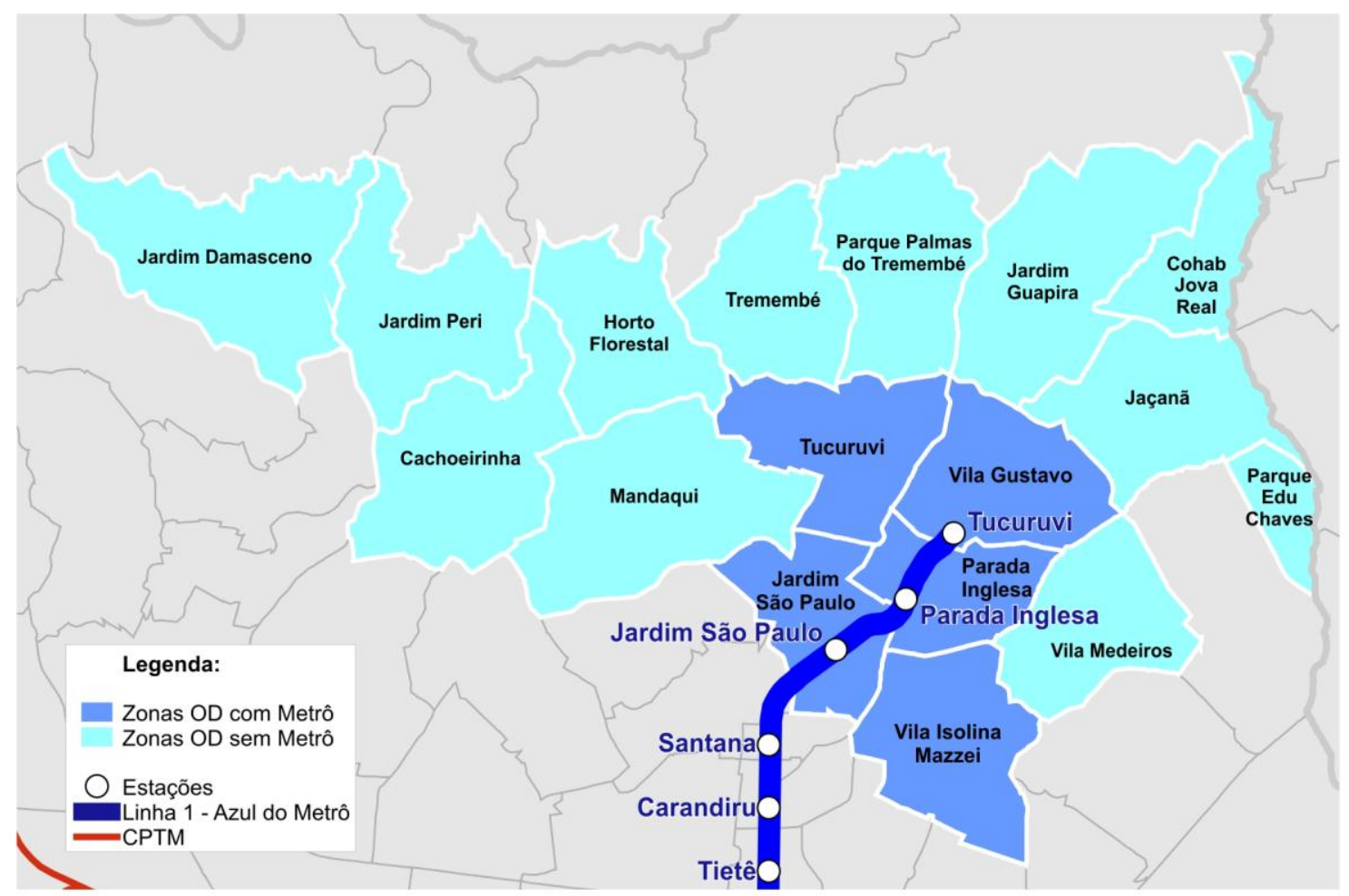

Figura 4-2. Zonas selecionadas para o estudo no entorno da Linha 1 - Azul

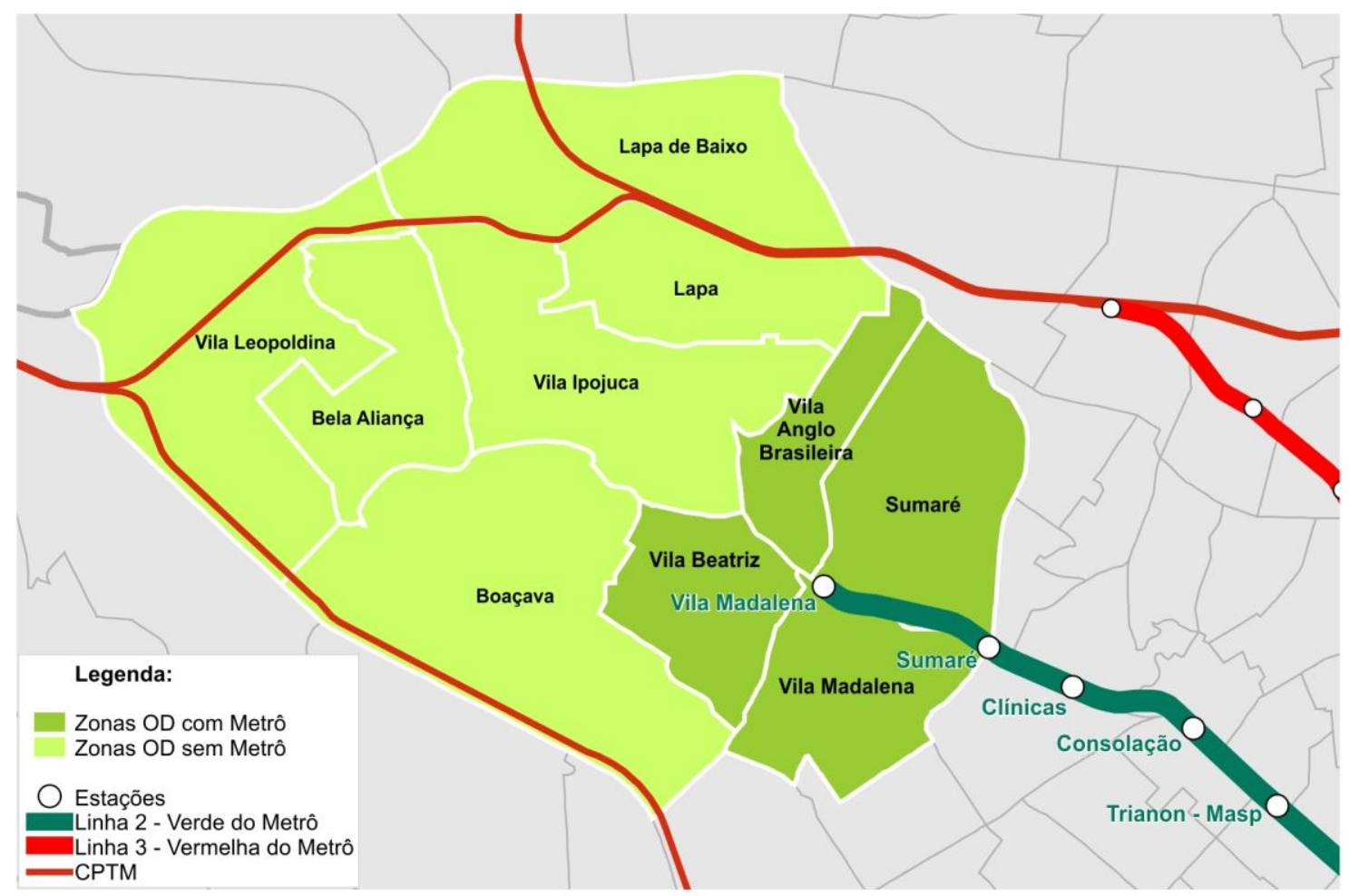

Figura 4-3. Zonas selecionadas para o estudo no entorno da Linha 2 - Verde 


\subsection{Metodologia para análise das viagens}

Para as viagens, as seguintes características são analisadas:

- Modo das viagens;

- Natureza da atividade - motivo na origem quando a zona de estudo é origem da viagem, ou motivo no destino quando a zona de estudo é destino da viagem.

$\mathrm{Na}$ análise, os seguintes modos de transporte são considerados:

- Coletivo: viagens realizadas nos transportes coletivos da RMSP, incluindo também ônibus fretados e transportes escolares. Este modo foi subdividido de forma a capturar a influência do Metrô nas zonas estudadas;

- Individual: viagens de automóvel, como motorista ou passageiro, motos e passageiros de taxi;

- Não motorizado: viagens realizadas de bicicleta ou a pé.

Para a natureza das atividades (motivo de viagem) localizadas na zona, a classificação das pesquisas O/D foi utilizada:

- Residência;

- Trabalho - agregando Trabalho em Comércio, Indústria e Serviços;

- Educação;

- Outros - agregando os motivos Compras, Lazer e Saúde e Outros relatados na O/D.

É importante notar que viagens entre as zonas de um grupo (inclusive as intrazonais) podem ser computadas duas vezes na classificação por Natureza das Atividades, pois tanto sua origem como seu destino são relevantes, quando ambos se encontram nas zonas estudadas. Por este motivo os valores totais não 
representam o total de viagens, mas sim o total estimado de extremos de viagem associado às atividades realizadas na zona.

A análise comparou os grupos distintos espacialmente - Grupo com Metrô, sem Metrô e RMSP - e temporalmente - entre 1997 e 2007.

\subsection{Metodologia para avaliar a influência de características socioeconômicas sobre as viagens}

Primeiramente foram analisadas algumas características socioeconômicas nos grupos com Metrô, sem Metrô e RMSP.

As seguintes características foram consideradas:

- População;

- Número de Famílias;

- Renda Média Familiar;

- Posse de automóveis (Taxa de motorização familiar).

É importante ressaltar que parte da amostra apresentou não-resposta para a renda familiar e a Companhia do Metrô imputou valores de renda para essas famílias utilizando as características socioeconômicas respondidas e a zona de residência da família, obtendo valores médios para cada caso de não-resposta. Os dados aqui utilizados incluem os imputados pelo Metrô.

Esses dados foram comparados temporalmente, entre 1997 e 2007, para cada grupo e espacialmente, entre os grupos.

A seguir, as famílias foram agrupadas em categorias, de acordo com as faixas de renda utilizadas pelo Metrô e padronizadas para Outubro de 2007:

- Renda familiar:

○ Inferior a $\mathrm{R} \$ 760,00$;

○ $\mathrm{R} \$ 760,00$ a $\mathrm{R} \$ 1.520,00$;

○ $\mathrm{R} \$ 1.520,00$ a $\mathrm{R} \$ 3.040,00$; 
- $R \$ 3.040,00$ a $R \$ 5.700,00$;

- Superior a $\mathrm{R} \$ 5.700,00$.

As seguintes características foram analisadas segundo faixas de renda:

- Número de famílias;

- Taxa média de motorização familiar;

- Taxa média de viagens por família.

As taxas de motorização familiar não levam em consideração as famílias que apresentaram não-resposta na questão sobre posse de automóvel.

\subsection{Metodologia para comparação dos dois casos estudados}

Tradicionalmente, estudos de casos são tratados individualmente e comparados posteriormente (Gil, 2002, pg.142). Assim, como se estudam dois casos de extensão de linha de Metrô, eles são expostos em sequência e, após suas conclusões individuais, é feita a comparação.

As análises comparativas entre os dois casos, Linha 1 - Azul e Linha 2 - Verde, utilizam apenas os Grupos com Metrô, obtendo-se comparação de:

- Viagens;

- Características socioeconômicas.

\subsection{Metodologia para análise desagregada}

Realizou-se uma análise desagregada utilizando todas as 2.960 famílias amostradas nas zonas dos Grupos com Metrô e sem Metrô de ambas as extensões de linha. Foram excluídas da análise 73 famílias que possuíam não-resposta quanto à posse de automóvel. Utilizaram-se os dados amostrais sem expansão.

Inicialmente, buscou-se verificar a influência da proximidade à estação na posse de automóvel. Para tanto, fez-se necessária a inserção de uma nova variável:

- Distância até a estação de Metrô mais próxima 
Para a obtenção dessas distâncias, utilizou-se a localização de cada família e da estação de Metrô mais próxima, obtidas através das coordenadas das residências contidas na O/D 2007 e de coordenadas disponibilizadas pela Companhia do Metrô de São Paulo para as cinco estações analisadas. As coordenadas são referenciadas no sistema UTM Córrego Alegre 23 Sul.

Sabe-se das distorções que a distância estimada por linha reta entre as coordenadas pode causar, no entanto, optou-se por esta aproximação por se tratar de uma análise de escala, na qual a precisão de caminho não se fazia essencial.

Esta parte da pesquisa utilizou somente os dados da O/D2007, pois não existem dados georreferenciados dos domicílios na O/D 97 que permitissem associar as famílias ao local onde foram construídas posteriormente as estações.

Utilizou-se um modelo de escolha discreta, o Logit Binomial. Este modelo se baseia em uma função de utilidade $(U)$ que expressa o grau de preferência por uma alternativa em função de atributos das alternativas e características socioeconômicas. Esta função, em sua forma mais simples pode ser definida como:

$$
U=\alpha_{0}+\alpha_{1} x_{1}+\alpha_{2} x_{2}+\ldots+\alpha_{n} x_{n}+\varepsilon_{0}
$$

Onde $x_{i}$ são as variáveis explicativas e $\varepsilon_{0} \circ$ termo de erro.

No Logit Binomial, as probabilidades de escolha entre duas alternativas A e B são definidas por:

$$
p(A)=\frac{1}{1+e^{\left(U_{B}-U_{A}\right)}}, \text { e } p(B)=1-p(A) .
$$

Através deste modelo, os usuários escolhem entre $A$ ou $B$ levando em conta a utilidade de cada alternativa, que é definida de acordo com os valores para as variáveis explicativas para cada usuário.

Assim, usuários com diferentes valores para cada variável explicativa verão utilidades diferentes para cada modo e tomarão decisões que podem ser distintas.

Uma explicação mais aprofundada sobre o Logit Binomial, assim como outros modelos de escolha discreta, pode ser obtida no livro de Train (2009). 
Para uma compreensão da influência do entorno da estação de Metrô na motorização familiar, realizou-se uma análise utilizando um modelo Logit Binomial para a posse de automóvel familiar (com automóvel x sem automóvel) em função das seguintes variáveis explicativas da família:

- Renda familiar;

- Tamanho da família;

- Distância da residência à estação de Metrô mais próxima;

- Viagens de metrô realizadas pelos membros da família;

- Viagens à pé realizadas pelos membros da família;

- Viagens de bicicleta realizadas pelos membros da família.

Para estimar o modelo foi utilizado um software livre denominado Biogeme (Bierlaire, 2003, 2008), que pode ser encontrado no site http://biogeme.epfl.ch/.

Também se buscou verificar a influência da proximidade à estação na quantidade total de viagens e na quantidade de viagens a pé realizada pelas famílias. Para tanto se utilizou um modelo de regressão linear, definido pela função:

$$
v=\alpha_{0}+\alpha_{1} x_{1}+\alpha_{2} x_{2}+\ldots+\alpha_{n} x_{n}
$$

Onde v é o número de viagens realizado pela família e os $x_{i}$ são características da família e de sua localização. As seguintes variáveis explicativas foram utilizadas:

- Renda familiar;

- Tamanho da família;

- Quantidade de automóveis;

- Distância da residência à estação de Metrô mais próxima;

- Matrículas na zona de residência;

- Empregos na zona de residência.

Para a realização das regressões lineares foi utilizado um aplicativo livre para Excel denominado Action, encontrado no site http://www.portalaction.com.br/. 


\section{Análise dos dados}

\subsection{Estudo do prolongamento da Linha 1 - Azul}

\subsubsection{Análise dos modos de viagem}

Primeiramente foi feita uma análise dos modos das viagens para os grupos de zonas. Os resultados são apresentados na Tabela 5-1, ressaltando em verde os aumentos percentuais ocorridos entre os anos das duas pesquisas, em vermelho as reduções e em amarelo os casos em que ocorreu a manutenção do percentual. A tabela mostra os resultados para cada zona do Grupo com Metrô e os valores agregados para os grupos com Metrô, sem Metrô e RMSP.

A coluna Metrô apresenta aquelas viagens, dentre o total, que acessaram a zona diretamente pelo modo Metrô (primeiro modo na origem ou último no destino).

Tabela 5-1. Viagens por modo - Linha 1 - Azul

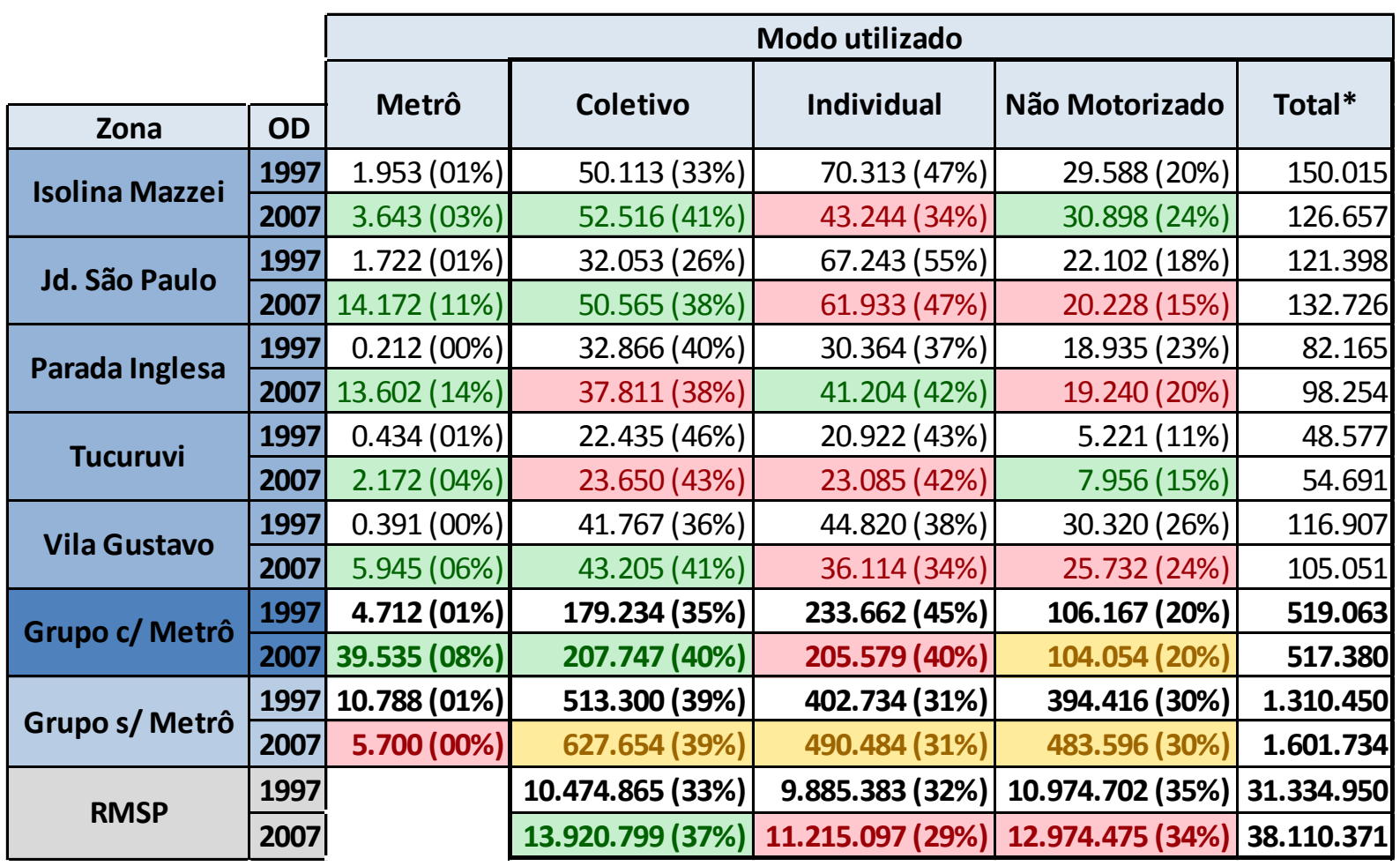

*Não considera o modo "Outros" especificado nas pesquisas O/D

Observa-se que o Grupo com Metrô não apresentou alteração nos totais de viagem entre 1997 e 2007, porém houve uma alteração na composição das viagens, com o modo coletivo aumentando de $35 \%$ para $40 \%$ e se igualando ao modo 
individual, que caiu de $45 \%$ para $40 \%$. As viagens deste grupo que acessaram as zonas consideradas diretamente pelo modo Metrô tiveram um aumento de 1\% para $8 \%$ do total de viagens, auxiliando nessa mudança de composição.

O Grupo sem Metrô apresentou um aumento superior a $20 \%$ no total das viagens, seguindo o ocorrido na RMSP. No entanto, manteve a divisão modal exatamente como em 1997. Para este grupo se observa que o modo coletivo já ultrapassava o modo individual em 1997.

Quanto a esta manutenção da divisão modal das viagens do Grupo sem Metrô, buscou-se verificar as mudanças no transporte coletivo da região. Observou-se que as viagens da região para esta linha de Metrô utilizavam anteriormente a estação Santana e a partir da inauguração da extensão passaram a acessar a estação Tucuruvi, com muitas das linhas de ônibus tendo seus pontos finais transferidos de uma estação para a outra.

Nota-se que no Grupo com Metrô o coletivo não ultrapassou o modo individual, como aconteceu na Região Metropolitana de São Paulo, porque apesar do aumento do modo coletivo, o modo individual também apresenta um valor mais elevado para este Grupo em comparação com a RMSP. Este percentual maior do modo individual no Grupo com Metrô ocorre às custas da participação do modo não-motorizado, que é de apenas $20 \%$, enquanto nos grupos de controle é superior a $30 \%$.

À respeito do modo não-motorizado também é notável que sua participação na divisão modal das viagens não se alterou entre os anos de pesquisa no Grupo com Metrô, sugerindo que a inserção da estação não provocou um incentivo a viagens a pé no entorno, uma vez que no Grupo sem Metrô o percentual de viagens a pé também não se alterou. A topografia da região, com o chamado "mar de morros" paulistano pode ter contribuído para este fator.

\subsubsection{Análise da Natureza das Atividades}

A análise da Natureza das Atividades nos grupos de zonas pode indicar mudanças de uso do solo ocorridas no entorno das estações estudadas.

Para tanto, realizou-se uma análise de tais atividades, observando os motivos nos extremos de viagem em cada zona de estudo. Os resultados são mostrados na 
Tabela 5-2, evidenciando, em verde, os casos em que houve um aumento do percentual de viagens em cada categoria de atividade ao longo desses dez anos, em vermelho, os casos em que houve redução e, em amarelo, os casos em que houve manutenção dos percentuais.

Tabela 5-2. Extremos de viagem por Natureza das atividades - Linha 1 - Azul

\begin{tabular}{|c|c|c|c|c|c|c|}
\hline & \multicolumn{5}{|c|}{ Natureza de Atividades } \\
\hline & & Residência & Trabalho & Educação & Outros & Total \\
\hline \multirow{2}{*}{ Isolina Mazzei } & 1997 & $93.450(47 \%)$ & $42.183(21 \%)$ & $34.178(17 \%)$ & $30.589(15 \%)$ & 200.399 \\
\hline & 2007 & $65.633(40 \%)$ & $46.241(28 \%)$ & $32.688(20 \%)$ & $21.157(13 \%)$ & 165.719 \\
\hline \multirow{2}{*}{ Jd. São Paulo } & 1997 & $83.623(50 \%)$ & $26.073(15 \%)$ & $28.954(17 \%)$ & $29.601(18 \%)$ & 168.251 \\
\hline & 2007 & $62.057(35 \%)$ & 51.556 (29\%) & $26.908(15 \%)$ & $38.492(22 \%)$ & 179.014 \\
\hline \multirow{2}{*}{ Parada Inglesa } & 1997 & $71.335(62 \%)$ & $25.977(23 \%)$ & $9.326(08 \%)$ & $7.700(07 \%)$ & 114.340 \\
\hline & 2007 & $63.444(45 \%)$ & $34.758(25 \%)$ & $17.632(12 \%)$ & $25.799(18 \%)$ & 141.633 \\
\hline \multirow{2}{*}{ Tucuruvi } & 1997 & $36.128(50 \%)$ & $13.006(18 \%)$ & $16.652(23 \%)$ & $6.710(09 \%)$ & 72.495 \\
\hline & 2007 & $28.511(37 \%)$ & $17.087(22 \%)$ & $24.135(31 \%)$ & $7.268(09 \%)$ & 77.001 \\
\hline \multirow{2}{*}{ Vila Gustavo } & 1997 & $76.730(42 \%)$ & $45.635(25 \%)$ & $38.717(21 \%)$ & $22.507(12 \%)$ & 183.589 \\
\hline & 2007 & $86.125(52 \%)$ & $25.724(16 \%)$ & $29.368(18 \%)$ & $22.889(14 \%)$ & 164.106 \\
\hline \multirow{2}{*}{ Grupo c/ Metrô } & 1997 & $361.266(49 \%)$ & $152.874(21 \%)$ & $127.827(17 \%)$ & $97.107(13 \%)$ & 739.074 \\
\hline & 2007 & $305.771(42 \%)$ & $175.366(24 \%)$ & $130.731(18 \%)$ & $115.605(16 \%)$ & 727.473 \\
\hline \multirow{2}{*}{ Grupo s/ Metrô } & 1997 & $1.139 .532(60 \%)$ & $257.499(14 \%)$ & $307.717(16 \%)$ & $183.978(10 \%)$ & 1.888 .726 \\
\hline & 2007 & $1.403 .150(62 \%)$ & $341.284(15 \%)$ & $360.062(16 \%)$ & $172.691(08 \%)$ & 2.277.187 \\
\hline \multirow{2}{*}{ RMSP } & 1997 & 28.485.152 (45\%) & $14.149 .579(23 \%)$ & 11.123.253 (18\%) & 9.106.426(14\%) & 62.864 .410 \\
\hline & 2007 & $34.899 .159(46 \%)$ & $18.485 .851(24 \%)$ & $13.863 .353(18 \%)$ & 9.222.199(12\%) & 76.470 .562 \\
\hline
\end{tabular}

Os valores totais dos extremos de viagem estimados são cerca de $40 \%$ maiores que o total das viagens por modo (Tabela 5-1). Isto ocorre devido às viagens entre as zonas do grupo (inclusive as intrazonais), que possuem atividades computadas duas vezes, uma na origem e outra no destino. Para a RMSP, os totais de atividades dobram em relação aos totais dos modos de viagem, pois toda viagem é computada duas vezes na metrópole (incluindo o modo Outros que não consta na Tabela 5-1).

Os totais de atividades para o Grupo com Metrô praticamente não se alteraram enquanto os totais de atividades para o Grupo sem Metrô e da RMSP sofreram um acréscimo de cerca de $20 \%$, o que é compatível com o verificado na Tabela 5-1 para os modos de viagem.

Como se pode notar, o percentual de atividade de residência no Grupo com Metrô diminuiu. Além disso, as atividades de trabalho e educação, assim como outras atividades, aumentaram. 
No grupo sem Metrô, e na RMSP como um todo, o percentual de atividades de residência aumentou ligeiramente enquanto atividades trabalho cresceram somente $1 \%$ e outras atividades diminuíram.

\subsubsection{Influência de características socioeconômicas sobre as viagens}

Realizou-se análise de algumas características socioeconômicas no período entre as pesquisas. A Tabela 5-3 mostra esta análise comparando a variação das características nos grupos com a variação da RMSP. Onde ocorreu valor percentual maior que a média da RMSP, assinalou-se em verde, manutenção em relação a esta, amarelo, e redução em relação a esta média, em vermelho.

Tabela 5-3 - Características Socioeconômicas - Linha 1 - Azul

\begin{tabular}{|c|c|c|c|c|c|c|}
\hline & & \multicolumn{5}{|c|}{ Características Socioeconômicas } \\
\hline & & \multirow[b]{2}{*}{ População } & \multirow[b]{2}{*}{ Famílias } & \multirow{2}{*}{$\begin{array}{c}\text { Renda Média } \\
\text { Familiar* }\end{array}$} & \multirow{2}{*}{$\begin{array}{l}\text { Qtde } \\
\text { Auto }\end{array}$} & \multirow{2}{*}{$\begin{array}{l}\text { Auto/ } \\
\text { Fam** }\end{array}$} \\
\hline Zona & OD & & & & & \\
\hline \multirow{3}{*}{ Isolina Mazzei } & |1997| & 43.626 & 13.836 & 4.519 & 14.113 & 1,030 \\
\hline & 2007 & 39.359 & 12.191 & 2.845 & 8.699 & 0,714 \\
\hline & $\Delta \%$ & $-10 \%$ & $-12 \%$ & $-37 \%$ & $-38 \%$ & $-31 \%$ \\
\hline \multirow{3}{*}{ Jd. São Paulo } & 1997 & 41.158 & 13.290 & 5.113 & 14.612 & 1,099 \\
\hline & 2007 & 32.463 & 10.435 & 4.110 & 9.205 & 0,925 \\
\hline & \begin{tabular}{|l|l|}
$\Delta \%$ \\
\end{tabular} & $-21 \%$ & $-21 \%$ & $-20 \%$ & $-37 \%$ & $-16 \%$ \\
\hline \multirow{3}{*}{ Parada Inglesa } & 1997 & 36.539 & 11.167 & 4.648 & 9.176 & 0,822 \\
\hline & 2007 & 33.813 & 10.702 & 3.548 & 10.518 & 0,997 \\
\hline & $\Delta \%$ & $-7 \%$ & $-4 \%$ & $-24 \%$ & $15 \%$ & $21 \%$ \\
\hline \multirow{3}{*}{ Tucuruvi } & 1997 & 17.787 & 5.478 & 5.569 & 6.102 & 1,114 \\
\hline & 2007 & 15.452 & 4.833 & 3.729 & 5.238 & 1,084 \\
\hline & $\Delta \%$ & $-13 \%$ & $-12 \%$ & $-33 \%$ & $-14 \%$ & $-3 \%$ \\
\hline \multirow{3}{*}{ Vila Gustavo } & 1997 & 47.632 & 15.145 & 4.261 & 15.416 & 1,018 \\
\hline & 2007 & 42.502 & 13.061 & 2.895 & 9.820 & 0,752 \\
\hline & \begin{tabular}{|l|}
$\Delta \%$ \\
\end{tabular} & $-11 \%$ & $-14 \%$ & $-32 \%$ & $-36 \%$ & $-26 \%$ \\
\hline \multirow{3}{*}{ Grupo c/ Metrô } & 1997 & 186.742 & 58.915 & 4.709 & 59.419 & 1,011 \\
\hline & 2007 & 163.589 & 51.222 & 3.346 & 43.480 & 0,860 \\
\hline & \begin{tabular}{|l|}
$\Delta \%$ \\
\end{tabular} & $-12 \%$ & $-13 \%$ & $-29 \%$ & $-27 \%$ & $-15 \%$ \\
\hline \multirow{3}{*}{ Grupo s/ Metrô } & 1997 & 696.581 & 185.249 & 2.913 & 123.062 & 0,667 \\
\hline & 2007 & 767.151 & 218.262 & 2.201 & 141.375 & 0,655 \\
\hline & $\Delta \%$ & $10 \%$ & $18 \%$ & $-24 \%$ & $15 \%$ & $-2 \%$ \\
\hline \multirow{3}{*}{ RMSP } & 1997 & 16.792 .421 & 4.558 .379 & 3.042 & 3.092 .238 & 0,682 \\
\hline & 2007 & 19.534 .620 & 5.721.212 & 2.211 & 3.545.290 & 0,629 \\
\hline & $\Delta \%$ & $16 \%$ & $26 \%$ & $-27 \%$ & $15 \%$ & $-8 \%$ \\
\hline
\end{tabular}


É possível notar que o Grupo com Metrô apresentou uma redução de população, assim como do número de famílias, mantendo sua estrutura familiar média em 3,2 membros na família de 1997 para 2007. Esta redução está associada à redução de atividades de residência observada anteriormente para o mesmo grupo (Tabela 5-2).

O Grupo sem Metrô possui crescimento populacional e familiar com um tamanho médio familiar de 3,8 membros em 97 e 3,5 em 2007, algo muito próximo da média familiar da RMSP para o período.

A motorização por família diminuiu mais que a média da RMSP no Grupo com Metrô, sugerindo um efeito da proximidade com o Metrô sobre essa variável. No entanto, a motorização era maior em 1997 e em 2007 continuou maior do que nos grupos de controle, indicando que a posse de automóvel esteja relacionada a um maior poder aquisitivo da população deste grupo de zonas.

Quanto à renda, cabe ressaltar que segundo as pesquisas O/D a RMSP apresentou uma queda de poder aquisitivo de 1997 para 2007, comparando-se ambas no valor de Outubro de 2007 (valor referência para comparação no site do Metrô http://www.metro.sp.gov.br). Para considerar este efeito, comparou-se a variação de renda de cada grupo com a variação na RMSP.

O Grupo com Metrô apresentou uma queda na renda média familiar maior que a observada na RMSP e no Grupo sem Metrô, mantendo-se, porém, em um patamar bastante superior.

Para descrever melhor a evolução da renda familiar, dividiram-se as famílias segundo as faixas de renda utilizadas pelo Metrô, como apresentado na Tabela 5-4. Como para as outras análises, foi marcado em vermelho o decréscimo percentual entre 1997 e 2007, em verde o acréscimo percentual e em amarelo a manutenção. 
Tabela 5-4 - Distribuição das famílias em faixas de renda - Linha 1 - Azul

\begin{tabular}{|c|c|c|c|c|c|c|c|}
\hline & & \multicolumn{6}{|c|}{ Faixas de renda ( $R \$$ ) } \\
\hline Zona & OD & $\begin{array}{l}\text { inferior a } \\
\mathrm{R} \$ 760,00 \\
\end{array}$ & $\begin{array}{c}R \$ 760,00 \\
\text { a } R \$ 1520,00\end{array}$ & $\begin{array}{c}R \$ 1520,00 \\
\text { a } R \$ 3040,00\end{array}$ & $\begin{array}{c}R \$ 3040,00 \\
\text { a } R \$ 5700,00\end{array}$ & $\begin{array}{l}\text { superior a } \\
\mathrm{R} \$ 5700,00\end{array}$ & Total \\
\hline \multirow{2}{*}{ Isolina Mazzei } & 1997 & $1587(11 \%)$ & $1468(11 \%)$ & $2612(19 \%)$ & $3875(28 \%)$ & 4294 (31\%) & 13836 \\
\hline & 2007 & $980(08 \%)$ & $4138(34 \%)$ & $3474(28 \%)$ & $1800(15 \%)$ & $1798(15 \%)$ & 12191 \\
\hline \multirow{2}{*}{ Jd. São Paulo } & 1997 & $1968(15 \%)$ & $1177(09 \%)$ & $2790(21 \%)$ & $3113(23 \%)$ & $4241(32 \%)$ & 13290 \\
\hline & 2007 & $611(06 \%)$ & $2104(20 \%)$ & $2577(25 \%)$ & $2851(27 \%)$ & $2293(22 \%)$ & 10435 \\
\hline \multirow{2}{*}{ Parada Inglesa } & 1997 & $540(05 \%)$ & $1553(14 \%)$ & $2261(20 \%)$ & $3518(32 \%)$ & $3295(30 \%)$ & 11167 \\
\hline & 2007 & $1100(10 \%)$ & $2649(25 \%)$ & $3097(29 \%)$ & $1850(17 \%)$ & $2006(19 \%)$ & 10702 \\
\hline \multirow{2}{*}{ Tucuruvi } & 1997 & $181(03 \%)$ & $398(07 \%)$ & $1046(19 \%)$ & $1242(23 \%)$ & $2611(48 \%)$ & 5478 \\
\hline & 2007 & $184(04 \%)$ & $550(11 \%)$ & $1989(41 \%)$ & $1163(24 \%)$ & $947(20 \%)$ & 4833 \\
\hline \multirow{2}{*}{ Vila Gustavo } & 1997 & $1071(07 \%)$ & $2919(19 \%)$ & $4057(27 \%)$ & $1640(11 \%)$ & $5457(36 \%)$ & 15145 \\
\hline & 2007 & $1167(09 \%)$ & $2749(21 \%)$ & $4571(35 \%)$ & $3429(26 \%)$ & $1145(09 \%)$ & 13061 \\
\hline \multirow{2}{*}{ Grupo c/ Metrô } & 1997 & $5346(09 \%)$ & $7515(13 \%)$ & $12767(22 \%)$ & $13388(23 \%)$ & $19899(34 \%)$ & 58915 \\
\hline & 2007 & $4042(08 \%)$ & $12190(24 \%)$ & $15708(31 \%)$ & $11093(22 \%)$ & $8188(16 \%)$ & 51222 \\
\hline \multirow{2}{*}{ Grupo s/ Metrô } & 1997 & $29076(16 \%)$ & $43979(24 \%)$ & $56225(30 \%)$ & $35246(19 \%)$ & $20723(11 \%)$ & 185249 \\
\hline & 2007 & 37444 (17\%) & $64233(29 \%)$ & $75494(35 \%)$ & $30673(14 \%)$ & $10418(05 \%)$ & 218262 \\
\hline \multirow{2}{*}{ RMSP } & 1997 & 707055 (16\%) & $1061635(23 \%)$ & $1355846(30 \%)$ & $837943(18 \%)$ & $595901(13 \%)$ & 4558379 \\
\hline & 2007 & $979143(17 \%)$ & $1814904(32 \%)$ & $1836130(32 \%)$ & $743119(13 \%)$ & $347916(06 \%)$ & 5721212 \\
\hline
\end{tabular}

De um modo geral houve uma diminuição das famílias nas faixas acima de $\mathrm{R} \$ 3.040,00$ para todos os grupos.

Para o Grupo com Metrô a faixa abaixo de $\mathrm{R} \$ 760,00$ apresentou redução. As faixas entre $R \$ 1.520,00$ e $R \$ 3.040,00$ apresentaram aumento.

Para o Grupo sem Metrô a participação das famílias das faixas abaixo de $\mathrm{R} \$ 3.040,00$ apresentam crescimento, com as faixas médias apresentando o maior percentual de crescimento, algo parecido com o ocorrido na RMSP.

A Figura 5-1 apresenta uma comparação das distribuições de 1997 e 2007 para o Grupo com Metrô e sem Metrô, permitindo visualizar a variação da distribuição de renda para cada caso. 


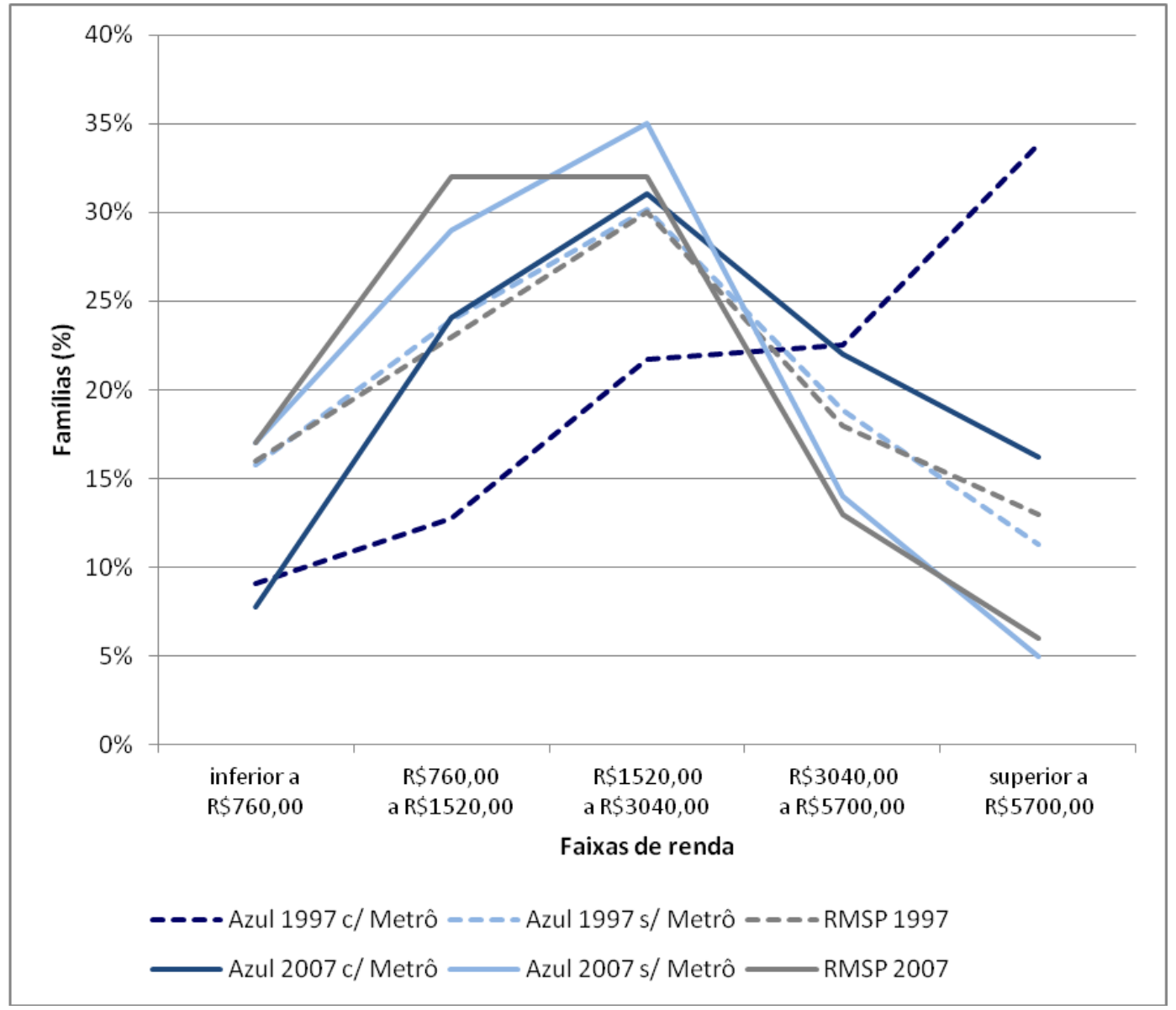

Figura 5-1 - Comparação da distribuição das famílias em faixas de renda entre Grupo com Metrô, sem Metrô e RMSP - Linha 1 - Azul

Como se pode observar, o Grupo com Metrô apresenta uma significativa queda da faixa superior a $\mathrm{R} \$ 5.700,00$ e grande aumento das faixas intermediárias. Além disso, ocorre pequena redução da faixa de renda inferior a $R \$ 760,00$.

Os grupos de controle se comportam de forma mais parecida, com crescimento semelhante nas três faixas inferiores e decréscimo também semelhante nas duas superiores.

Também foram estimadas as taxas de motorização por família segundo as faixas de renda para os grupos estudados. Os resultados podem ser observados na Tabela 5-5 e na Figura 5-2. Para casos de aumento na motorização entre 1997 e 2007, assinalou-se em verde o valor de 2007. Nos casos em que ela sofreu redução, assinalou-se em vermelho. 
Tabela 5-5 - Motorização familiar média por faixa de renda - Linha 1 - Azul

\begin{tabular}{|c|c|c|c|c|c|c|c|}
\hline & & \multicolumn{6}{|c|}{ Faixas de Renda (R\$) } \\
\hline Zona & OD & \begin{tabular}{|l|} 
inferior a \\
$\mathrm{R} \$ \mathbf{7 6 0 , 0 0}$
\end{tabular} & \begin{tabular}{|c|}
$\mathrm{R} \$ 760,00$ \\
a $R \$ 1520,00$
\end{tabular} & \begin{tabular}{|c|}
$R \$ 1520,00$ \\
a $R \$ 3040,00$
\end{tabular} & \begin{tabular}{|c|}
$R \$ 3040,00$ \\
a $R \$ 5700,00$
\end{tabular} & \begin{tabular}{|l} 
superior a \\
$\mathrm{R} \$ 5700,00$
\end{tabular} & $\begin{array}{l}\text { Média } \\
\text { Grupo }\end{array}$ \\
\hline \multirow{2}{*}{ Grupo c/ Metrô* } & 1997 & 0,302 & 0,460 & 0,585 & 0,938 & 1,731 & 1,011 \\
\hline & 2007 & 0,240 & 0,283 & 0,776 & 1,064 & 1,913 & 0,860 \\
\hline \multirow{2}{*}{ Grupo s/ Metrô* } & 1997 & 0,198 & 0,322 & 0,508 & 1,050 & 1,787 & 0,667 \\
\hline & 2007 & 0,193 & 0,311 & 0,722 & 1,355 & 1,907 & 0,655 \\
\hline \multirow{2}{*}{ RMSP* } & 1997 & 0,166 & 0,289 & 0,585 & 1,005 & 1,760 & 0,682 \\
\hline & 2007 & 0,162 & 0,295 & 0,735 & 1,247 & 1,834 & 0,629 \\
\hline
\end{tabular}

*Famílias com não-resposta sobre posse de automóvel desconsideradas

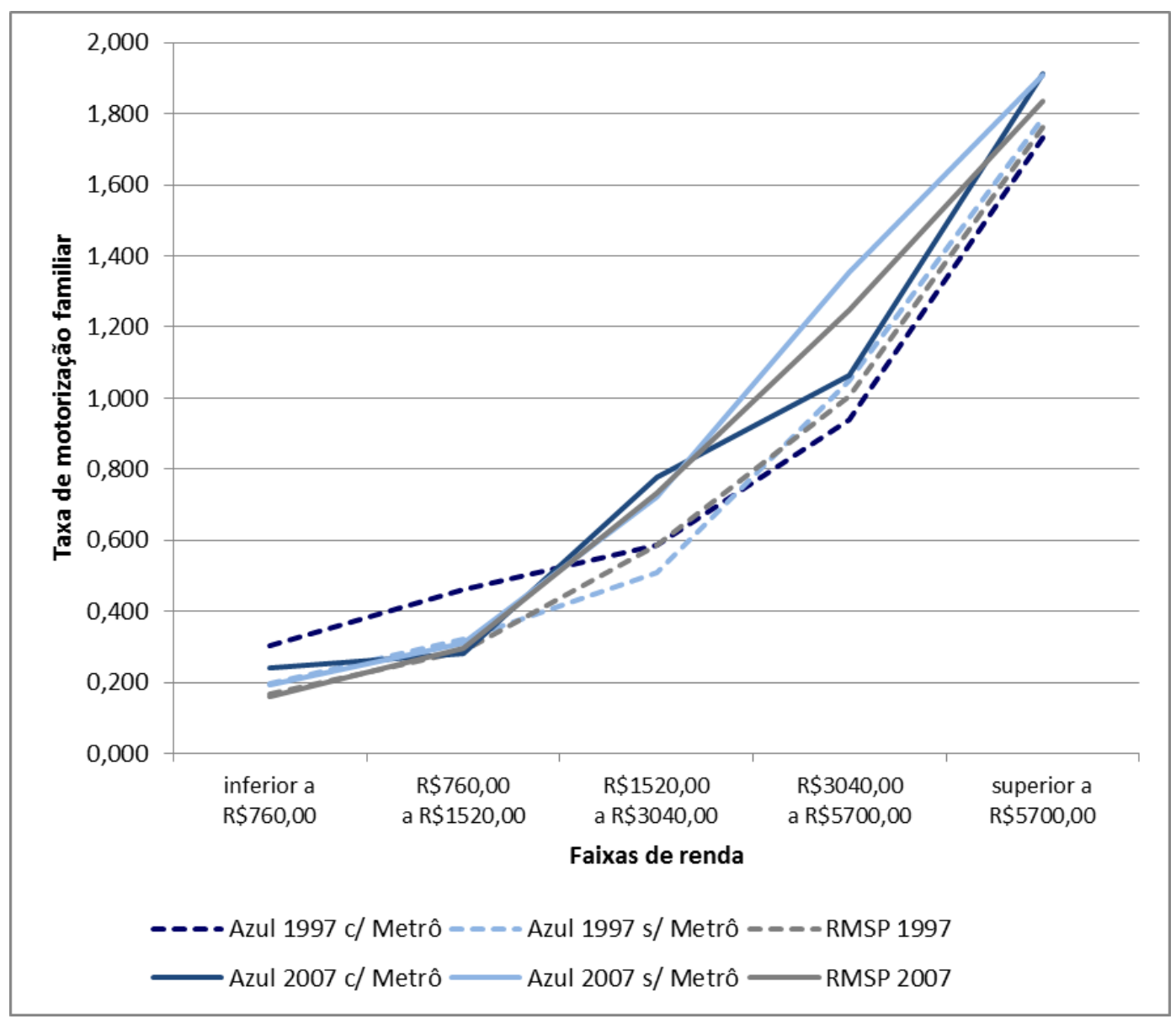

Figura 5-2 - Motorização familiar média por faixa de renda - Linha 1 - Azul

Destaca-se que a motorização familiar média dos grupos de zonas caiu de 1997 para 2007, independentemente das médias das faixas terem subido. Isto ocorre porque a distribuição das famílias se deslocou para faixas de renda mais baixas, que possuem taxas de motorização menores. 
Tanto o Grupo com Metrô como o sem Metrô tiveram uma redução na motorização para famílias com renda até $R \$ 1.520,00$, enquanto, na RMSP, essa redução só ocorre para a faixa com menos de $R \$ 760,00$ e ainda assim muito atenuada (queda de $2 \%$, de 0,166 para 0,162 automóveis/família).

É possível notar que a queda na motorização para as duas faixas de renda mais baixas é mais acentuada no Grupo com Metrô (21\% e 38\% de queda) que no Grupo sem Metrô (2\% e 3\%), sugerindo que tenha ocorrido um aumento de famílias sem automóvel nessas faixas de renda se mudando para próximo da estação.

As famílias de faixas de renda mais elevadas, em ambos os grupos, acompanham a tendência da RMSP.

Também se realizou uma análise das taxas médias de viagens por família para cada faixa de renda considerada. Ressalta-se que as viagens consideradas para este cálculo diferem dos totais de viagens por modo (Tabela 5-1), pois lá se computava viagens com origem ou destino na zona e aqui se computa viagens de famílias residentes nas zonas. Na Tabela 5-6 se pode ver a evolução entre 1997 e 2007, utilizando os mesmos critérios de apresentação anteriormente mencionados.

Tabela 5-6 - Taxas de viagens por família segundo faixas de renda - Linha 1 - Azul

\begin{tabular}{|c|c|c|c|c|c|c|c|}
\hline & & \multicolumn{6}{|c|}{ Faixas de Renda (R\$) } \\
\hline Zona & OD & $\begin{array}{l}\text { inferior a } \\
\mathrm{R} \$ 760,00\end{array}$ & \begin{tabular}{|c|}
$R \$ 760,00$ \\
a R\$1520,00
\end{tabular} & \begin{tabular}{|c|}
$\mathbf{R} 1520,00$ \\
a $R \$ 3040,00$
\end{tabular} & \begin{tabular}{|c|}
$R \$ 3040,00$ \\
a $R \$ 5700,00$
\end{tabular} & $\begin{array}{l}\text { superior a } \\
\mathrm{R} \$ 5700,00\end{array}$ & $\begin{array}{l}\text { Média } \\
\text { Grupo }\end{array}$ \\
\hline \multirow{2}{*}{ Grupo c/ Metrô } & 1997 & 2,024 & 4,487 & 6,592 & 8,191 & 9,437 & 7,234 \\
\hline & 2007 & 2,893 & 5,084 & 6,792 & 8,095 & 8,742 & 6,672 \\
\hline \multirow{2}{*}{ Grupo s/ Metrô } & 1997 & 3,679 & 6,009 & 6,512 & 8,082 & 10,897 & 6,737 \\
\hline & 2007 & 4,589 & 6,061 & 7,624 & 9,612 & 10,211 & 7,046 \\
\hline \multirow{2}{*}{ RMSP } & 1997 & 3,701 & 5,765 & 7,302 & 8,371 & 9,700 & 6,895 \\
\hline & 2007 & 4,117 & 5,875 & 7,329 & 8,672 & 10,056 & 6,658 \\
\hline
\end{tabular}

Destaca-se que a taxa de viagens familiar média do Grupo com Metrô caiu de 1997 para 2007, independente das médias das faixas terem subido. Novamente, isto ocorre porque a distribuição das famílias se deslocou para faixas mais baixas, que possuem taxas de viagem menores.

Para o Grupo com Metrô se pode notar aumento nas taxas de viagem para as faixas inferiores a $R \$ 3.040,00$, com uma redução para as faixas superiores. Dado que o tamanho médio da família no Grupo se manteve entre os anos de pesquisa 
(3,2 membros), como visto anteriormente, percebe-se um aumento da mobilidade individual das faixas mais baixas, com os indivíduos realizando mais viagens.

O Grupo sem Metrô apresenta um aumento para todas as faixas, exceto a superior a $\mathrm{R} \$ 5.700,00$. Percebe-se, neste caso, também um aumento da mobilidade das famílias da região, levando-se em consideração a redução do tamanho médio da família (de 3,8 para 3,5), observando-se um aumento mais acentuado na mobilidade individual.

Conclui-se, da análise desta extensão da Linha 1 - Azul, que o Grupo com Metrô apresentou significativa redução de população e número de famílias, ocasionando redução nas atividades de residência e uma manutenção dos totais de viagens.

O Grupo sem Metrô apresentou crescimento populacional e de viagens mais aderente aos da RMSP.

Quanto à motorização familiar média, o Grupo com Metrô apresentou a maior queda, porém continua com taxas mais altas que os grupos de controle. 


\subsection{Estudo do prolongamento da Linha 2 - Verde}

\subsubsection{Análise dos modos de viagem}

Primeiramente foi feita uma análise da divisão modal de viagens com origem ou destino nos grupos de zonas. Os resultados são apresentados na Tabela 5-7, ressaltando em verde os aumentos percentuais ocorridos entre os anos das duas pesquisas, em vermelho as reduções e em amarelo os casos em que ocorreu a manutenção do percentual.

A coluna Metrô apresenta aquelas viagens, dentre o total, que acessaram a zona diretamente pelo modo Metrô (primeiro modo na origem ou último no destino).

Tabela 5-7. Total de viagens por modo - Linha 2 - Verde

\begin{tabular}{|c|c|c|c|c|c|c|}
\hline \multirow[b]{2}{*}{ Zona } & \multirow[b]{2}{*}{ OD } & \multicolumn{5}{|c|}{ Modo utilizado } \\
\hline & & Metrô & Coletivo Total & Individual & Não Motorizado & Total* \\
\hline \multirow{2}{*}{ Vila Madalena } & 1997 & $3.522(03 \%)$ & $28.139(22 \%)$ & $72.806(57 \%)$ & $25.777(20 \%)$ & 126.721 \\
\hline & 2007 & $10.145(09 \%)$ & $37.403(35 \%)$ & $57.891(54 \%)$ & $12.391(12 \%)$ & 107.685 \\
\hline \multirow{2}{*}{ Sumaré } & 1997 & $3.142(02 \%)$ & $68.919(35 \%)$ & $106.432(54 \%)$ & $20.178(10 \%)$ & 195.529 \\
\hline & 2007 & $9.208(04 \%)$ & 70.590 (32\%) & $125.285(56 \%)$ & $27.248(12 \%)$ & 223.124 \\
\hline \multirow{2}{*}{ Vila Anglo Brasileira } & 1997 & $1.352(02 \%)$ & $33.284(53 \%)$ & $23.320(37 \%)$ & $6.581(10 \%)$ & 63.184 \\
\hline & 2007 & $3.977(04 \%)$ & $32.164(35 \%)$ & $41.936(46 \%)$ & $17.828(19 \%)$ & 91.928 \\
\hline \multirow{2}{*}{ Vila Beatriz } & 1997 & $0.000(00 \%)$ & $20.032(38 \%)$ & $28.258(54 \%)$ & $3.801(07 \%)$ & 52.091 \\
\hline & 2007 & $4.619(07 \%)$ & $17.174(26 \%)$ & 42.569 (65\%) & $6.245(09 \%)$ & 65.988 \\
\hline \multirow{2}{*}{ Grupo c/ Metrô } & 1997 & $8.016(02 \%)$ & $150.373(34 \%)$ & $230.816(53 \%)$ & $56.336(13 \%)$ & 437.525 \\
\hline & 2007 & $27.949(06 \%)$ & $157.332(32 \%)$ & $267.681(55 \%)$ & $63.713(13 \%)$ & 488.726 \\
\hline \multirow{2}{*}{ Grupo s/ Metrô } & 1997 & $2.162(00 \%)$ & $318.928(44 \%)$ & $333.471(46 \%)$ & $75.203(10 \%)$ & 727.601 \\
\hline & 2007 & $8.708(01 \%)$ & $456.775(51 \%)$ & $363.303(40 \%)$ & $77.994(09 \%)$ & 898.071 \\
\hline \multirow{2}{*}{ RMSP } & 1997 & & $10.474 .865(33 \%)$ & $9.885 .383(32 \%)$ & $10.974 .702(35 \%)$ & 31.334 .950 \\
\hline & 2007 & & $13.920 .799(37 \%)$ & $11.215 .097(29 \%)$ & $12.974 .475(34 \%)$ & 38.110 .371 \\
\hline
\end{tabular}

*Não considera o modo "Outros" especificado nas pesquisas O/D

Observa-se que o Grupo com Metrô apresentou apenas 11\% de elevação nos totais de viagem entre 1997 e 2007 e praticamente uma manutenção na divisão modal das viagens, com o modo coletivo reduzindo de $34 \%$ para $32 \%$ e o modo individual, aumentando de $53 \%$ para $55 \%$. As viagens deste grupo que acessaram as zonas consideradas diretamente pelo modo Metrô tiveram um aumento de $2 \%$ para $6 \%$ do total de viagens e este crescimento aconteceu às custas de outros modos de transporte coletivo.

O Grupo sem Metrô apresentou um aumento superior a $20 \%$ nos totais das 
viagens, seguindo o ocorrido na RMSP, apresentando uma grande mudança de composição com a inversão do modo coletivo - de $44 \%$ para $51 \%$ - às custas do individual - de $46 \%$ para $40 \%$.

Nota-se que no Grupo com Metrô o coletivo não ultrapassou o modo individual, como aconteceu no Grupo sem Metrô e na RMSP.

À respeito do modo não-motorizado também é notável que sua participação não se alterou entre os anos de pesquisa no Grupo com Metrô, sugerindo que a inserção da estação não provocou um incentivo a viagens à pé no entorno. Salientase que para o Grupo sem Metrô o percentual de viagens à pé diminuiu de apenas $1 \%$, permanecendo também praticamente inalterado. $O$ baixo percentual de viagens não motorizadas na região sugere um alto poder aquisitivo e o Grupo com Metrô ainda se localiza em uma área de relevo acidentado da Zona Oeste Paulistana.

\subsubsection{Análise da Natureza das Atividades}

Como no caso anterior realizou-se uma análise de Natureza de Atividades, observando os motivos nos extremos de viagem para cada zona de estudo. Os resultados são mostrados na Tabela 5-8, evidenciando os casos em que houve um aumento do percentual de viagens para as atividades ao longo desses dez anos em verde, os casos em que houve redução em vermelho e, manutenção dos percentuais em amarelo.

Tabela 5-8. Extremos de viagem por Natureza das atividades - Linha 2 - Verde

\begin{tabular}{|c|c|c|c|c|c|c|}
\hline \multirow[b]{2}{*}{ Zona } & \multirow[b]{2}{*}{ OD } & \multicolumn{5}{|c|}{ Natureza de Atividades } \\
\hline & & Residência & Trabalho & Educação & Outros & Total \\
\hline \multirow{2}{*}{ Vila Madalena } & 1997 & $61.388(38 \%)$ & $46.589(29 \%)$ & $22.984(14 \%)$ & $29.641(18 \%)$ & 160.602 \\
\hline & 2007 & $46.782(36 \%)$ & $39.743(31 \%)$ & $16.054(12 \%)$ & $27.226(21 \%)$ & 129.806 \\
\hline \multirow{2}{*}{ Sumaré } & 1997 & $109.672(44 \%)$ & $66.050(27 \%)$ & $34.747(14 \%)$ & $36.100(15 \%)$ & 246.568 \\
\hline & 2007 & $133.487(50 \%)$ & $70.993(26 \%)$ & $20.092(07 \%)$ & $45.071(17 \%)$ & 269.643 \\
\hline \multirow{2}{*}{ Vila Anglo Brasileira } & 1997 & $33.944(41 \%)$ & $34.613(42 \%)$ & $9.329(11 \%)$ & $4.057(05 \%)$ & 81.943 \\
\hline & 2007 & $50.897(44 \%)$ & $31.846(28 \%)$ & $17.738(15 \%)$ & $15.188(13 \%)$ & 115.669 \\
\hline \multirow{2}{*}{ Vila Beatriz } & \begin{tabular}{|l|}
1997 \\
\end{tabular} & $36.590(56 \%)$ & $11.659(18 \%)$ & $10.584(16 \%)$ & $6.163(09 \%)$ & 64.995 \\
\hline & 2007 & $41.545(47 \%)$ & $20.367(23 \%)$ & $14.356(16 \%)$ & $11.485(13 \%)$ & 87.753 \\
\hline \multirow{2}{*}{ Total c/ Metrô } & 1997 & $230.375(41 \%)$ & $171.664(30 \%)$ & $80.853(14 \%)$ & $80.525(14 \%)$ & 563.417 \\
\hline & 2007 & $247.340(47 \%)$ & $138.538(26 \%)$ & $54.446(10 \%)$ & $88.245(17 \%)$ & 528.568 \\
\hline \multirow{2}{*}{ Total s/ Metrô } & 1997 & $231.317(25 \%)$ & $376.596(41 \%)$ & $107.891(12 \%)$ & $212.184(23 \%)$ & 927.988 \\
\hline & 2007 & $227.232(21 \%)$ & $507.919(46 \%)$ & $109.282(10 \%)$ & $247.928(23 \%)$ & 1.092 .362 \\
\hline \multirow{2}{*}{ RMSP } & 1997 & $28.485 .152(45 \%)$ & $14.149 .579(23 \%)$ & $11.123 .253(18 \%)$ & $9.106 .426(14 \%)$ & 62.864 .410 \\
\hline & 2007 & $34.899 .159(46 \%)$ & $18.485 .851(24 \%)$ & $13.863 .353(18 \%)$ & $9.222 .199(12 \%)$ & 76.470 .562 \\
\hline
\end{tabular}


Os valores totais desta tabela representam o total de extremos de viagem estimado. Assim, o Grupo com Metrô apresenta aproximadamente totais 28\% maiores que o total das viagens por modo em 1997 e 8\% em 2007, mostrando que o percentual referente a viagens entre as zonas do grupo (inclusive as intrazonais) diminuíram de 1997 para 2007, mostrando que o Metrô facilitou o aumento de viagens para fora das zonas do grupo ao melhorar a acessibilidade à cidade. $O$ Grupo sem Metrô apresenta totais 28\% maiores em 1997 e 21\% em 2007. Para a RMSP este valor dobra, pois toda viagem acaba computada duas vezes neste caso (incluindo o modo Outros que não consta na Tabela 5-7).

Como se pode notar, o percentual de atividade de residência no Grupo com Metrô aumentou de 6\%. Além disso, as atividades de trabalho e educação diminuíram de cerca de $4 \%$ cada atividade.

No grupo sem Metrô ocorre o inverso, com a atividade residência tendo queda de $4 \%$ e a atividade trabalho tendo um acréscimo 5\%.

O Grupo sem Metrô, apesar de não estar próximo à rede metroviária, é cortado pelas linhas 7, 8 e 9 da CPTM, com esta última tendo sofrido modernização no período, sendo possível que elas estejam influenciando os resultados de forma a assemelhar o Grupo sem Metrô da extensão da Linha 2 - Verde ao Grupo com Metrô da extensão da Linha 1 - Azul. Além disso, a região da Lapa é um centro comercial consolidado e este conjunto de fatores pode ser o responsável por propiciar este comportamento.

Na RMSP como um todo, o percentual de atividades de residência aumentou ligeiramente enquanto atividades trabalho cresceram somente $1 \%$.

A atividade residência em duas das zonas do grupo reduziu enquanto que as outras zonas do grupo com Metrô tiveram um crescimento na atividade, sendo necessário investigar características populacionais e ainda um possível aumento nas viagens realizadas pelos habitantes dessas zonas.

Além disso, o modo trabalho aumentou também nas mesmas duas zonas, reduzindo-se nas outras zonas, indicando que a legislação de zoneamento do município também pode ter impedido o crescimento de atividades de trabalho. 


\subsubsection{Influência de características socioeconômicas sobre as viagens}

Realizou-se análise de algumas características socioeconômicas no período entre as pesquisas. A Tabela 5-9 mostra esta análise comparando a variação das características nos grupos com a variação da RMSP. Onde ocorreu valor percentual maior que a média da RMSP, assinalou-se em verde, manutenção em relação a esta, amarelo, e redução em relação a esta média, em vermelho.

Tabela 5-9 - Características Socioeconômicas - Linha 2 - Verde

\begin{tabular}{|c|c|c|c|c|c|c|}
\hline & & \multicolumn{5}{|c|}{ Características Socioeconômicas } \\
\hline & & \multirow[b]{2}{*}{ População } & \multirow[b]{2}{*}{ Famílias } & \multirow{2}{*}{$\begin{array}{c}\text { Renda Média } \\
\text { Familiar* }\end{array}$} & \multirow{2}{*}{$\begin{array}{l}\text { Qtde } \\
\text { Auto }\end{array}$} & \multirow{2}{*}{$\begin{array}{l}\text { Auto/ } \\
\text { Fam }\end{array}$} \\
\hline Zona & OD & & & & & \\
\hline \multirow{3}{*}{ Vila Madalena } & 1997 & 24.297 & 7.093 & $\mathrm{R} \$ 6.433,30$ & 8.950 & 1,26 \\
\hline & 2007 & 20.073 & 7.448 & $\mathrm{R} \$ 5.585,20$ & 8.202 & 1,08 \\
\hline & $\Delta \%$ & $-17 \%$ & $5 \%$ & $-13 \%$ & $-8 \%$ & $-14 \%$ \\
\hline \multirow{3}{*}{ Sumaré } & 1997 & 53.778 & 18.927 & $\mathrm{R} \$ 5.902,50$ & 23.875 & 1,26 \\
\hline & 2007 & 37.368 & 13.282 & $\mathrm{R} \$ 6.210,13$ & 16.364 & 1,25 \\
\hline & $\Delta \%$ & $-31 \%$ & $-30 \%$ & $5 \%$ & $-31 \%$ & $-1 \%$ \\
\hline \multirow{3}{*}{ Vila Anglo Brasileira } & 1997 & 22.444 & 7.315 & $\mathrm{R} \$ 4.548,94$ & 7.133 & 0,98 \\
\hline & 2007 & 21.560 & 7.850 & $R \$ 3.654,27$ & 6.883 & 0,87 \\
\hline & $\Delta \%$ & $-4 \%$ & $7 \%$ & $-20 \%$ & $-4 \%$ & $-10 \%$ \\
\hline \multirow{3}{*}{ Vila Beatriz } & 1997 & 18.938 & 6.058 & $\mathrm{R} \$ 7.018,65$ & 7.458 & 1,23 \\
\hline & 2007 & 17.972 & 6.058 & $\mathrm{R} \$ 5.651,18$ & 8.020 & 1,30 \\
\hline & \begin{tabular}{|l|}
$\Delta \%$ \\
\end{tabular} & $-5 \%$ & $0 \%$ & $-19 \%$ & $8 \%$ & $6 \%$ \\
\hline \multirow{3}{*}{ Grupo c/ Metrô } & 1997 & 119.457 & 39.393 & $\mathrm{R} \$ 5.918,39$ & 47.415 & 1,20 \\
\hline & 2007 & 113.786 & 40.626 & $\mathrm{R} \$ 5.456,26$ & 47.342 & 1,16 \\
\hline & $\Delta \%$ & $-5 \%$ & $3 \%$ & $-8 \%$ & $0 \%$ & $-4 \%$ \\
\hline \multirow{3}{*}{ Grupo s/ Metrô } & 1997 & 114.833 & 37.089 & $\mathrm{R} \$ 5.859,64$ & 41.726 & 1,13 \\
\hline & 2007 & 103.241 & 34.838 & $\mathrm{R} \$ 4.384,43$ & 36.180 & 1,07 \\
\hline & $\Delta \%$ & $-10 \%$ & $-6 \%$ & $-25 \%$ & $-13 \%$ & $-5 \%$ \\
\hline \multirow{3}{*}{ RMSP } & 1997 & 16.792 .421 & 4.558 .379 & $\mathrm{R} \$ 3.041,52$ & 3.092 .238 & 0,68 \\
\hline & 2007 & 19.534 .620 & 5.721 .212 & $\mathrm{R} \$ \mathbf{2 . 2 1 0 , 9 7}$ & 3.545 .290 & 0,63 \\
\hline & \begin{tabular}{|l|}
$\Delta \%$ \\
\end{tabular} & $16 \%$ & $26 \%$ & $-27 \%$ & $15 \%$ & $-9 \%$ \\
\hline
\end{tabular}

*Em Reais de Outubro de 2007

** Descontadas famílias com não-resposta para posse de automóvel

É possível notar que o Grupo com Metrô apresentou uma redução de população da ordem de $5 \%$, o que condiz com o ocorrido no caso da Linha 1 - Azul. No entanto, houve um aumento de famílias da ordem de $3 \%$, indicando famílias com um número menor de membros neste grupo, reduzindo o tamanho médio familiar de 3,1 para 2,8 membros. 
O Grupo sem Metrô apresenta decréscimo populacional de 10\% e familiar de $6 \%$, mantendo um tamanho médio familiar de 3 membros entre 97 e 2007, valor menor que a média da RMSP, que passou de 3,7 em 97 para 3,4 em 2007.

A motorização por família diminuiu menos que a média da RMSP no Grupo com Metrô, o que condiz com o aumento percentual de viagens pelo modo individual observado para este grupo (Tabela 5-7). Além disso, a motorização já era maior em 1997 e em 2007 continuou superior aos grupos de controle, indicando que a posse de automóvel esteja relacionada a um maior poder aquisitivo da população deste grupo de zonas.

O Grupo sem Metrô apresenta motorização superior à RMSP, mas ambos apresentam quedas semelhantes.

Quanto à renda, cabe ressaltar que segundo as pesquisas O/D a RMSP apresentou uma queda de poder aquisitivo de 1997 para 2007, comparando-se ambas no valor de Outubro de 2007 (valor referência para comparação no site do Metrô http://www.metro.sp.gov.br). Para considerar este efeito, comparou-se a variação de renda de cada zona e grupo com a variação na RMSP.

O Grupo com Metrô se manteve bem acima da média da RMSP, indicando presença de famílias de rendas elevadas, enquanto o Grupo sem Metrô apresentou uma queda de poder aquisitivo semelhante à metrópole.

Para descrever melhor a evolução da renda familiar, dividiram-se as famílias segundo as faixas de renda deste estudo são utilizadas pelo Metrô, dividindo as famílias em grupos, como apresentado na Tabela 5-10. Como para as outras análises, foi marcado em vermelho um decréscimo percentual em relação ao mesmo dado em 1997, em verde um acréscimo percentual e em amarelo uma manutenção. 
Tabela 5-10 - Distribuição de famílias por faixa de renda - Grupo com Metrô - Linha 2 - Verde

\begin{tabular}{|c|c|c|c|c|c|c|c|}
\hline \multirow[b]{2}{*}{ Zona } & \multirow[b]{2}{*}{ OD } & \multicolumn{6}{|c|}{ Faixas de renda (R\$) } \\
\hline & & $\begin{array}{l}\text { inferior a } \\
\mathrm{R} \$ 760,00 \\
\end{array}$ & $\begin{array}{c}R \$ 760,00 \\
\text { a } R \$ 1520,00\end{array}$ & $\begin{array}{c}R \$ 1520,00 \\
\text { a } R \$ 3040,00\end{array}$ & $\begin{array}{c}R \$ 3040,00 \\
\text { a } R \$ 5700,00\end{array}$ & $\begin{array}{l}\text { superior a } \\
\mathrm{R} \$ 5700,00 \\
\end{array}$ & Total \\
\hline \multirow{2}{*}{ Vila Madalena } & 1997 & $446(06 \%)$ & $136(02 \%)$ & $717(10 \%)$ & $2012(28 \%)$ & $3782(53 \%)$ & 7093 \\
\hline & 2007 & $397(05 \%)$ & $633(09 \%)$ & $1638(22 \%)$ & $1862(25 \%)$ & $2917(39 \%)$ & 7448 \\
\hline \multirow{2}{*}{ Sumaré } & 1997 & $622(03 \%)$ & $1469(08 \%)$ & $4592(24 \%)$ & $4977(26 \%)$ & $7267(38 \%)$ & 18927 \\
\hline & 2007 & $509(03 \%)$ & 1690 (09\%) & $4421(23 \%)$ & $5176(27 \%)$ & 7474 (39\%) & 19270 \\
\hline \multirow{2}{*}{ Vila Anglo Brasileira } & 1997 & $674(09 \%)$ & $512(07 \%)$ & $1485(20 \%)$ & $2599(36 \%)$ & $2044(28 \%)$ & 7315 \\
\hline & 2007 & $891(11 \%)$ & $1279(16 \%)$ & $2184(28 \%)$ & $1719(22 \%)$ & $1777(23 \%)$ & 7850 \\
\hline \multirow{2}{*}{ Vila Beatriz } & 1997 & $409(07 \%)$ & $578(10 \%)$ & $1416(23 \%)$ & $313(05 \%)$ & $3341(55 \%)$ & 6058 \\
\hline & 2007 & $351(06 \%)$ & $588(10 \%)$ & $1225(20 \%)$ & $1479(24 \%)$ & $2415(40 \%)$ & 6058 \\
\hline \multirow{2}{*}{ Total c/ Metrô } & 1997 & $2151(05 \%)$ & $2695(07 \%)$ & $8210(21 \%)$ & $9901(25 \%)$ & $16435(42 \%)$ & 39393 \\
\hline & 2007 & $2148(05 \%)$ & $4191(10 \%)$ & $9468(23 \%)$ & $10236(25 \%)$ & $14583(36 \%)$ & 40626 \\
\hline \multirow{2}{*}{ Total s/ Metrô } & 1997 & $2983(08 \%)$ & $6073(16 \%)$ & $6431(17 \%)$ & $7316(20 \%)$ & $14286(39 \%)$ & 37089 \\
\hline & 2007 & $2482(07 \%)$ & $4816(14 \%)$ & $8843(25 \%)$ & $9654(28 \%)$ & $9042(26 \%)$ & 34836 \\
\hline \multirow{2}{*}{ RMSP } & 1997 & $707055(16 \%)$ & $1061635(23 \%)$ & $1355846(30 \%)$ & $837943(18 \%)$ & $595901(13 \%)$ & 4558379 \\
\hline & 2007 & $979143(17 \%)$ & $1814904(32 \%)$ & $1836130(32 \%)$ & $743119(13 \%)$ & $347916(06 \%)$ & 5721212 \\
\hline
\end{tabular}

Observa-se, no Grupo com Metrô, o crescimento percentual de famílias que possuem entre $R \$ 760,00$ e $R \$ 5.700,00$ de renda familiar, a manutenção dos percentuais para faixa inferior a $R \$ 760,00$ e entre $R \$ 3.040,00$ e $R \$ 5.700,00$, e o decréscimo na faixa superior a $\mathrm{R} \$ 5.700,00$.

No grupo sem Metrô as famílias com renda inferior a $\mathrm{R} \$ 1.520,00$ decresceram, as faixas médias - entre $R \$ 1.520,00$ e $R \$ 5.700,00$ - sofreram crescimento e a faixa mais elevada - acima de $\mathrm{R} \$ 5.700,00$ decresceu.

A RMSP apresenta crescimento para as três faixas inferiores a $R \$ 3.040,00$ e decréscimo para as faixas mais altas de renda.

Como se observa, os grupos possuem valores percentuais mais elevados para as faixas mais altas se comparados à RMSP, com uma queda de $42 \%$ para $36 \%$ para o Grupo com Metrô e de $39 \%$ para $26 \%$, enquanto a queda na RMSP é de $13 \%$ para $6 \%$.

$\mathrm{Na}$ faixa de renda mais baixa, o Grupo com Metrô apresenta manutenção do percentual de $5 \%$ e o sem Metrô ligeira queda de $8 \%$ para $7 \%$, enquanto a RMSP cresce de $16 \%$ para $17 \%$.

A Figura 5-3 apresenta uma comparação das distribuições entre 1997 e 2007 para o Grupo com Metrô e sem Metrô, permitindo visualizar a variação da 
distribuição para cada caso.

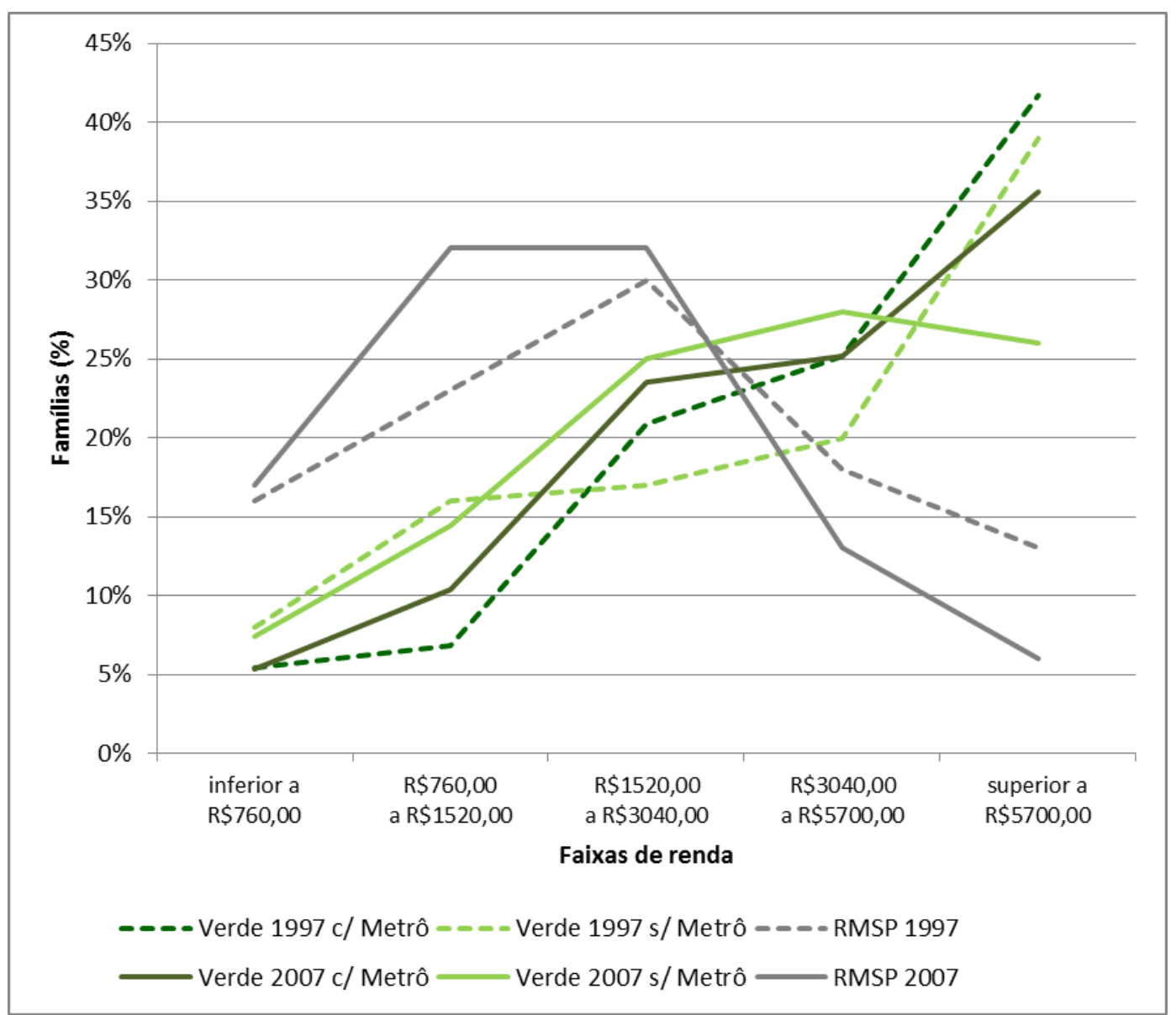

Figura 5-3 - Comparação da distribuição da população por faixas de renda entre Grupo com Metrô e sem Metro da extensão da Linha 2 - Verde

Nota-se que o decréscimo da faixa mais alta acontece de forma atenuada no Grupo com Metrô. Para o Grupo sem Metrô, a queda é consideravelmente maior.

Mesmo o crescimento das faixas intermediárias, observado no Grupo com Metrô, é mais atenuado que as transformações dos grupos de controle, demonstrando uma tendência de manutenção da distribuição.

O Grupo sem Metrô apresenta um crescimento de faixas médias e redução das faixas baixas que também é distinto do que ocorre na RMSP como um todo.

Seguindo a mesma lógica do outro caso de extensão de linha estudado, analisou-se a taxa de motorização familiar média para cada faixa de renda, que pode ser observada na Tabela 5-11 e Figura 5-4. 
Tabela 5-11 - Motorização familiar média por faixa de renda - Linha 2 - Verde

\begin{tabular}{|c|c|c|c|c|c|c|c|}
\hline & & \multicolumn{6}{|c|}{ Classes de Renda (R\$) } \\
\hline Zona & OD & $\begin{array}{l}\text { inferior a } \\
\mathrm{R} \$ 760,00\end{array}$ & \begin{tabular}{|c|}
$\mathbf{R} \$ 760,00$ \\
a R\$1520,00
\end{tabular} & \begin{tabular}{|l|}
$\mathbf{R} \$ 1520,00$ \\
a $\mathbf{R} \$ 3040,00$
\end{tabular} & \begin{tabular}{|c|}
$R \$ 3040,00$ \\
a $R \$ 5700,00$
\end{tabular} & $\begin{array}{l}\text { superior a } \\
R \$ 5700,00\end{array}$ & $\begin{array}{l}\text { Média } \\
\text { Grupo }\end{array}$ \\
\hline \multirow{2}{*}{ Grupo c/ Metrô* } & 1997 & 0,088 & 0,115 & 0,849 & 1,151 & 1,737 & 1,204 \\
\hline & 2007 & 0,363 & 0,315 & 0,654 & 1,235 & 1,799 & 1,157 \\
\hline \multirow{2}{*}{ Grupo s/ Metrô* } & 1997 & 0,537 & 0,408 & 0,505 & 0,940 & 1,927 & 1,125 \\
\hline & 2007 & 0,128 & 0,274 & 0,665 & 1,283 & 1,969 & 1,067 \\
\hline \multirow{2}{*}{ RMSP } & 1997 & 0,166 & 0,289 & 0,585 & 1,005 & 1,760 & 0,682 \\
\hline & 2007 & 0,162 & 0,295 & 0,735 & 1,247 & 1,834 & 0,629 \\
\hline
\end{tabular}

*Famílias com não-resposta sobre posse de automóvel desconsideradas

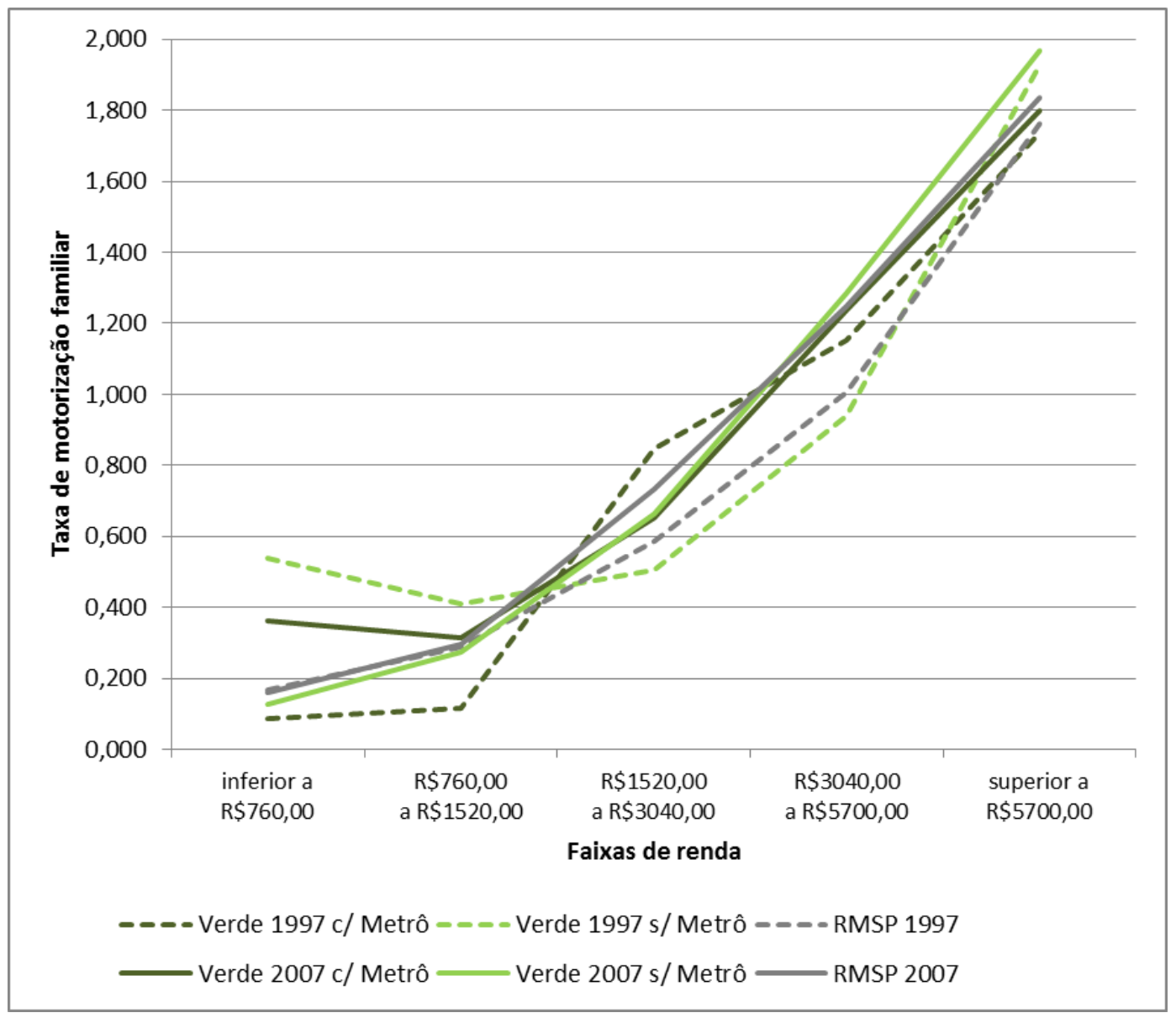

Figura 5-4 - Motorização familiar média por faixa de renda - Linha 2 - Verde

Destaca-se que a motorização familiar média dos grupos caiu de 1997 para 2007, independente das médias das faixas terem subido. Isto ocorre porque a distribuição das famílias se deslocou para faixas de renda mais baixas, que possuem taxas de motorização menores.

O Grupo com Metrô teve uma redução na motorização apenas para famílias com renda entre $R \$ 1.520,00$ e $R \$ 3.040,00$ enquanto, na RMSP, essa redução ocorre para a faixa com menos de $\mathrm{R} \$ 760,00$. 
Esta região possui valores de motorização muito superiores aos da RMSP e considera-se que o padrão de renda alto da região seja o responsável por essa manutenção da motorização.

Há uma redução de motorização observada para rendas menores de $\mathrm{R} \$ 1.520,00$ no grupo sem Metrô, sendo uma redução considerável quando comparada à RMSP. O acréscimo da motorização para as faixas de renda superiores a $\mathrm{R} \$ 1.520,00$ acompanha o crescimento para a RMSP.

Também se realizou uma análise das taxas de viagens por família para cada faixa de renda considerada. Ressalta-se que as viagens utilizadas para este cálculo diferem dos totais de viagens por modo, pois lá se computava viagens com origem ou destino na zona e aqui se computa viagens de famílias residentes nas zonas. $\mathrm{Na}$ Tabela 5-12 se pode ver a evolução entre 1997 e 2007, utilizando os mesmos critérios de apresentação anteriormente mencionados.

Tabela 5-12 - Taxas de viagens por família segundo faixas de renda - Linha 2 - Verde

\begin{tabular}{|c|c|c|c|c|c|c|c|}
\hline & & \multicolumn{6}{|c|}{ Faixas de Renda (R\$̣) } \\
\hline Zona & OD & $\begin{array}{l}\text { inferior a } \\
\mathrm{R} \$ 760,00\end{array}$ & $\begin{array}{c}\text { R\$760,00 } \\
\text { a } R \$ 1520,00\end{array}$ & \begin{tabular}{|c|}
$R \$ 1520,00$ \\
a $R \$ 3040,00$
\end{tabular} & \begin{tabular}{|c|}
$\mathrm{R} \$ 3040,00$ \\
a R\$5700,00
\end{tabular} & $\begin{array}{l}\text { superior a } \\
R \$ 5700,00\end{array}$ & $\begin{array}{l}\text { Média } \\
\text { Grupo }\end{array}$ \\
\hline \multirow{2}{*}{ Grupo c/ Metrô } & 1997 & 1,893 & 3,050 & 5,261 & 7,130 & 10,228 & 7,468 \\
\hline & 2007 & 3,890 & 4,837 & 6,390 & 7,683 & 11,144 & 8,130 \\
\hline \multirow{2}{*}{ Grupo s/ Metrô } & 1997 & 3,541 & 4,257 & 5,786 & 7,798 & 10,094 & 7,411 \\
\hline & 2007 & 2,621 & 4,882 & 6,638 & 7,953 & 10,477 & 7,469 \\
\hline \multirow{2}{*}{ RMSP } & 1997 & 3,701 & 5,765 & 7,302 & 8,371 & 9,700 & 6,895 \\
\hline & 2007 & 4,117 & 5,875 & 7,329 & 8,672 & 10,056 & 6,658 \\
\hline
\end{tabular}

Destaca-se que a taxa média de viagens familiar média dos grupos subiu de 1997 para 2007, tanto para o Grupo com Metrô como para o Grupo sem Metrô.

Nota-se um crescimento na média de viagens por família para todas as faixas do Grupo com Metrô, fato semelhante ao que ocorre na RMSP. Como ocorreu uma redução do tamanho médio da família (de 3,1 para 2,8 membros), isto representa um aumento na mobilidade individual para este grupo.

Para o Grupo sem Metrô ocorre decréscimo para a faixa inferior a $\mathrm{R} \$ 760,00$. Para as outras faixas o grupo apresenta crescimento. Com a manutenção do tamanho médio da família ( 3 membros), isto representa uma queda na mobilidade para a faixa mais baixa e um aumento para as demais. 
Em geral as viagens por famílias de ambos os grupos cresceram mais que a média metropolitana.

Conclui-se, da análise desta extensão da Linha 2 - Verde, que o Grupo com Metrô apresentou redução de população e um aumento no número de famílias, havendo aumento nas atividades de residência e uma ligeiro aumento dos totais de viagens.

O Grupo sem Metrô apresentou decréscimo populacional e aumento de viagens, com aumento mais significativo ocorrendo nas viagens pelo modo coletivo e para atividade de trabalho, indicando que o grupo possui configuração de polo de atração.

Quanto à motorização familiar média, o Grupo com Metrô apresentou a maior queda, porém continua com taxas mais altas que os grupos de controle. 


\subsection{Estudo comparativo dos casos}

Após o estudo dos dois casos de extensão de linha, realiza-se a comparação entre eles. Comparou-se somente os Grupos com Metrô de cada extensão estudada, permitindo extrair considerações sobre semelhanças e discrepâncias entre eles.

A primeira comparação realizada foi da divisão modal, como mostra a Tabela 5-13. Foram assinalados em verde os valores que tiveram aumento percentual entre os períodos das pesquisas, em vermelho, os que sofreram redução e, em amarelo, os que apresentaram manutenção percentual.

A coluna Metrô apresenta aquelas viagens, dentre o total, que acessaram a zona diretamente pelo modo Metrô (primeiro modo na origem ou último no destino).

Tabela 5-13 - Comparação da divisão modal

\begin{tabular}{|c|c|c|c|c|c|}
\cline { 3 - 6 } \multicolumn{2}{c|}{} & \multicolumn{4}{c|}{ Modo utilizado (\%) } \\
\cline { 2 - 6 } \multicolumn{2}{c|}{} & Metrô & Coletivo & Individual & $\begin{array}{c}\text { Não } \\
\text { Motorizado }\end{array}$ \\
\hline \multirow{2}{*}{ Linha 1 - Azul } & 1997 & $1 \%$ & $35 \%$ & $45 \%$ & $20 \%$ \\
\cline { 2 - 6 } & $\mathbf{2 0 0 7}$ & $8 \%$ & $40 \%$ & $40 \%$ & $20 \%$ \\
\hline \multirow{2}{*}{ Linha 2 - Verde } & 1997 & $2 \%$ & $34 \%$ & $53 \%$ & $13 \%$ \\
\cline { 2 - 6 } & $\mathbf{2 0 0 7}$ & $6 \%$ & $32 \%$ & $55 \%$ & $13 \%$ \\
\hline \multirow{2}{*}{ RMSP } & 1997 & & $33 \%$ & $32 \%$ & $35 \%$ \\
\cline { 2 - 6 } & $\mathbf{2 0 0 7}$ & & $37 \%$ & $29 \%$ & $34 \%$ \\
\cline { 4 - 6 } & & & & & \\
\cline { 4 - 6 } & & & & &
\end{tabular}

Observa-se que o Grupo com Metrô da Linha 1 - Azul teve um acréscimo de $5 \%$ nas viagens pelo modo coletivo, igualando-o ao modo individual, que decresceu 5\% no período. Já no Grupo com Metrô da Linha 2 - Verde, o modo individual aumentou $2 \%$, aumentando também a distância para o modo coletivo, que diminuiu $2 \%$.

Em ambos os casos se nota que a proporção do modo não-motorizado se manteve, o que indica que viagens não motorizadas no entorno não foram incentivadas pela presença da estação e das atividas que potencialmente atrairia. 
O Grupo da Linha 1 - Azul apresenta semelhança com a RMSP no uso do transporte coletivo. Porém, a despeito da presença do Metrô, os grupos de ambas as extensões de linha apresentam percentual de viagem pelo modo individual mais elevado que a média metropolitana.

Com relação às oportunidades de atividades na região próxima ao Metrô também se compararam os dois grupos, como pode ser observado na Tabela 5-14. Utilizaram-se os mesmos critérios de cores anteriormente explicados para crescimento, manutenção e queda percentual.

Tabela 5-14 - Comparação de Natureza das Atividades

\begin{tabular}{|c|c|c|c|c|c|c|}
\cline { 3 - 7 } \multicolumn{2}{c|}{} & \multicolumn{5}{c|}{ Natureza de Atividades } \\
\cline { 3 - 7 } \multicolumn{2}{c|}{} & Resid. & Trabalho & Edu. & Outros & Total \\
\hline \multirow{2}{*}{ Linha 1 - Azul } & $\mathbf{1 9 9 7}$ & $49 \%$ & $21 \%$ & $17 \%$ & $13 \%$ & 739.074 \\
\cline { 2 - 7 } & $\mathbf{2 0 0 7}$ & $42 \%$ & $24 \%$ & $18 \%$ & $16 \%$ & 727.473 \\
\hline \multirow{2}{*}{ Linha 2 - Verde } & 1997 & $41 \%$ & $30 \%$ & $14 \%$ & $14 \%$ & 563.417 \\
\cline { 2 - 7 } & $\mathbf{2 0 0 7}$ & $47 \%$ & $26 \%$ & $10 \%$ & $17 \%$ & 528.568 \\
\hline \multirow{2}{*}{ RMSP } & $\mathbf{1 9 9 7}$ & $45 \%$ & $23 \%$ & $18 \%$ & $14 \%$ & 62.864 .410 \\
\cline { 2 - 7 } & $\mathbf{2 0 0 7}$ & $46 \%$ & $24 \%$ & $18 \%$ & $12 \%$ & 76.470 .562 \\
\hline
\end{tabular}

Para ambos os casos o total de atividades se altera muito pouco, demonstrando uma semelhança entre os dois casos e disparidade com relação aos grupos sem Metrô observados anteriormente e com a RMSP. Os grupos de controle apresentaram aumento na quantidade de atividades estimadas, mas para os grupos com Metrô as atividades não aumentaram.

Com relação às atividades, os dois casos se mostram muito díspares, dado que no entorno da extensão da Linha 1 - Azul ocorre uma redução da atividade residência e aumento da atividade trabalho, enquanto no entorno da Linha 2 - Verde ocorre exatamente o oposto.

Este resultado pode estar relacionado à vocação dos trechos, tendo o Tucuruvi ganhado uma condição de polo de atração local para a Região Norte (Passos, 2011), enquanto na Região Oeste a Lapa e adjacências já assumiam esta posição, fazendo com que o entorno da extensão da Linha 2 - Verde, anteriormente já fortemente residencial, mantivesse este padrão. 
Esta explicação se relaciona com a população e com outras características socioeconômicas, que foram comparadas e mostradas na Tabela 5-15.

Tabela 5-15 - Comparação de Características Socioeconômicas

\begin{tabular}{|c|c|c|c|c|c|c|}
\hline & & \multicolumn{5}{|c|}{ Características Socioeconômicas } \\
\hline & & Pop. & Fam. & $\begin{array}{c}\text { Renda } \\
\text { Familiar* }\end{array}$ & $\begin{array}{l}\text { Qtde } \\
\text { Auto }\end{array}$ & $\begin{array}{c}\text { Auto/ } \\
\text { Fam }\end{array}$ \\
\hline \multirow{3}{*}{ Linha 1 - Azul } & 1997 & 186.742 & 58.915 & $\mathrm{R} \$ 4.708,67$ & 59.419 & 1,01 \\
\hline & 2007 & 163.589 & 51.222 & $\mathrm{R} \$ 3.345,69$ & 43.480 & 0,86 \\
\hline & $\Delta \%$ & $-14 \%$ & $-15 \%$ & $-41 \%$ & $-37 \%$ & $-19 \%$ \\
\hline \multirow{3}{*}{ Linha 2 - Verde } & 1997 & 119.457 & 39.393 & $\mathrm{R} \$ 5.918,39$ & 47.415 & 1,20 \\
\hline & 2007 & 113.786 & 40.626 & $R \$ 5.456,26$ & 47.342 & 1,16 \\
\hline & $\Delta \%$ & $-5 \%$ & $3 \%$ & $-8 \%$ & $0 \%$ & $-3 \%$ \\
\hline \multirow{3}{*}{ RMSP } & 1997 & 16.792.421 & 4.558 .379 & $\mathrm{R} \$ 3.041,52$ & 3.092 .238 & 0,68 \\
\hline & 2007 & 19.534 .620 & 5.721 .212 & $\mathrm{R} \$ 2.210,97$ & 3.545 .290 & 0,63 \\
\hline & $\Delta \%$ & $16 \%$ & $26 \%$ & $-27 \%$ & $15 \%$ & $-9 \%$ \\
\hline
\end{tabular}

* Em Reais de Outubro de 2007

Como observado, a população de ambos os grupos de zonas decresceu, porém, enquanto na Linha 1 - Azul ocorre uma redução no número de famílias, mantendo o tamanho médio de 3,2, na Linha 2 - Verde ocorre um aumento no número de famílias, com o tamanho médio caindo de 3,1 para 2,8. Este segundo fato se relaciona com um aumento de área consumida por essas famílias menores através de empreendimento residenciais de padrão mais elevado (Macêdo, 2010).

A renda média familiar é mais elevada neste trecho da Linha 2 - Verde que no trecho da Linha 1 - Azul, porém, em ambos os casos é mais elevada que na RMSP, mostrando que o Metrô foi instalado em locais já considerados valorizados, do ponto de vista de uso do solo, na metrópole paulistana.

A posse do automóvel também é mais elevada em ambos os casos quando comparadas à RMSP, mas também é possível observar que ela é mais intensa no trecho da Linha 2 - Verde, o que é compreensível dado que a posse do automóvel é fortemente atrelada à renda e este grupo é o que apresenta maior renda.

Realizou-se também uma comparação da distribuição das famílias por faixas de renda para os casos estudados, que pode ser observada na Tabela 5-16 e na Figura 5-5. 
Tabela 5-16 - Comparação da distribuição das famílias segundo faixas de renda

\begin{tabular}{|c|c|c|c|c|c|c|}
\hline & & \multicolumn{5}{|c|}{ Faixas de Renda (R\$̧) } \\
\hline Zona & OD & $\begin{array}{l}\text { inferior a } \\
\mathrm{R} \$ \mathbf{7} 760,00\end{array}$ & $\begin{array}{c}\mathbf{R} \$ 760,00 \\
\text { a R\$1520,00 }\end{array}$ & \begin{tabular}{|c|}
$R \$ 1520,00$ \\
a $R \$ 3040,00$
\end{tabular} & $\begin{array}{c}R \$ 3040,00 \\
\text { a } R \$ 5700,00\end{array}$ & $\begin{array}{l}\text { superior a } \\
\mathrm{R} \$ 5700,00 \\
\end{array}$ \\
\hline \multirow{2}{*}{ Linha 1 - Azul } & 1997 & $9 \%$ & $13 \%$ & $22 \%$ & $23 \%$ & $34 \%$ \\
\hline & 2007 & $8 \%$ & $24 \%$ & $31 \%$ & $21 \%$ & $16 \%$ \\
\hline \multirow{2}{*}{ Linha 2 - Verde } & 1997 & $5 \%$ & $7 \%$ & $21 \%$ & $25 \%$ & $42 \%$ \\
\hline & 2007 & $5 \%$ & $10 \%$ & $23 \%$ & $25 \%$ & $36 \%$ \\
\hline \multirow{2}{*}{ RMSP } & 1997 & $16 \%$ & $23 \%$ & $30 \%$ & $18 \%$ & $13 \%$ \\
\hline & 2007 & $17 \%$ & $32 \%$ & $32 \%$ & $13 \%$ & $6 \%$ \\
\hline
\end{tabular}

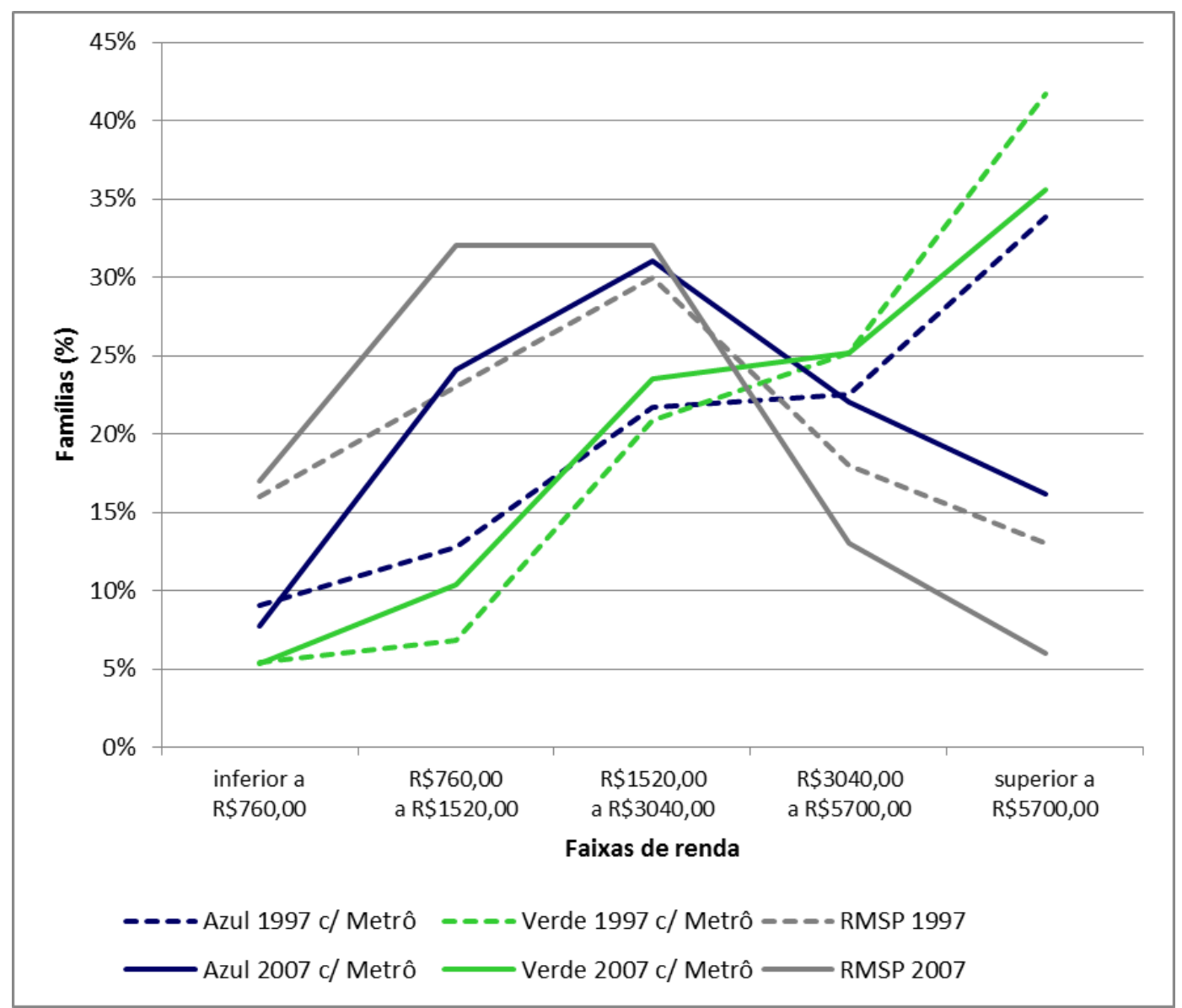

Figura 5-5 - Comparação da distribuição das famílias segundo faixas de renda

Como pode ser observado, os grupos com Metrô de ambos os casos possuíam uma distribuição semelhante de faixas de renda em 1997. Com a inserção do Metrô, ambos apresentaram uma elevação da concentração de população nas faixas de renda intermediárias, com a extensão da Linha 1 - Azul apresentando maior expressão nesse aumento.

Comparou-se também a motorização familiar ocorrida para os grupos das duas extensões de linha, como mostrado na Tabela 5-17 e Figura 5-6. 
Tabela 5-17 - Comparação da motorização familiar* média por faixas de renda

\begin{tabular}{|c|c|c|c|c|c|c|c|}
\hline & & \multirow{2}{*}{\multicolumn{6}{|c|}{ Faixas de Renda (R\$) }} \\
\hline & & & & & & \\
\hline Zona & OD & $\begin{array}{c}\text { inferior a } \\
R \$ 760,00\end{array}$ & $\begin{array}{c}\mathrm{R} \$ 760,00 \\
\text { a } \mathbf{R} \$ 1520,00\end{array}$ & $\begin{array}{c}\mathrm{R} \$ 1520,00 \\
\text { a } R \$ 3040,00\end{array}$ & $\begin{array}{c}R \$ 3040,00 \\
\text { a } R \$ 5700,00\end{array}$ & $\begin{array}{l}\text { superior a } \\
R \$ 5700,00\end{array}$ & $\begin{array}{l}\text { Média } \\
\text { Grupo }\end{array}$ \\
\hline \multirow{2}{*}{ Linha 1 - Azul } & $\mid 1997$ & 0,302 & 0,460 & 0,585 & 0,938 & 1,731 & 1,011 \\
\hline & 2007 & 0,240 & 0,283 & 0,776 & 1,064 & 1,913 & 0,860 \\
\hline \multirow{2}{*}{ Linha 2 - Verde } & 1997 & 0,088 & 0,115 & 0,849 & 1,151 & 1,737 & 1,204 \\
\hline & 2007 & 0,363 & 0,315 & 0,654 & 1,235 & 1,799 & 1,157 \\
\hline \multirow{2}{*}{ RMSP } & 1997 & 0,166 & 0,289 & 0,585 & 1,005 & 1,760 & 0,682 \\
\hline & 2007 & 0,162 & 0,295 & 0,735 & 1,247 & 1,834 & 0,629 \\
\hline
\end{tabular}

*Famílias com não-resposta sobre posse de automóvel desconsideradas

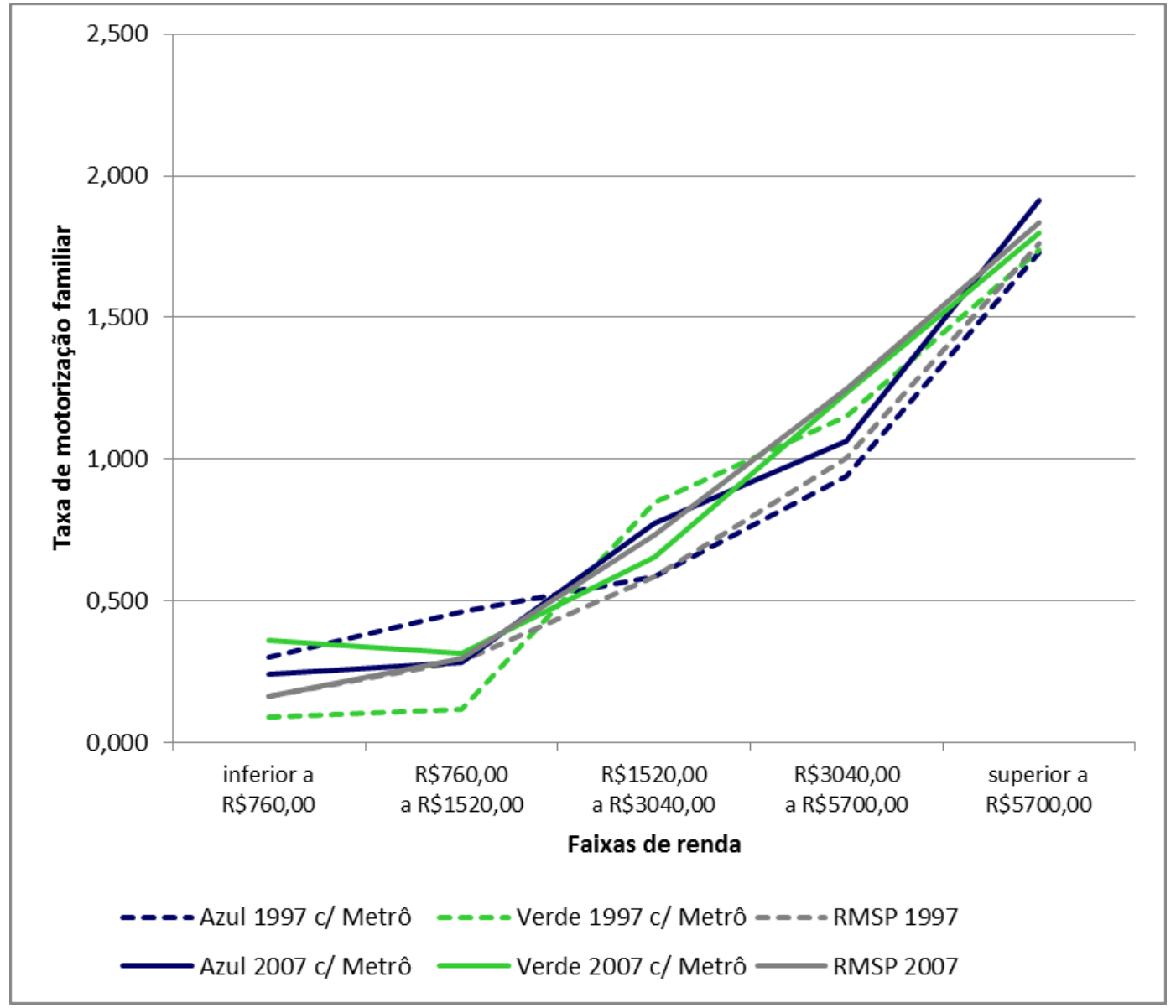

Figura 5-6 - Comparação da motorização familiar média por faixas de renda

Destaca-se que a motorização familiar média dos grupos caiu de 1997 para 2007, independente das médias das faixas terem subido. Isto ocorre porque a distribuição das famílias se deslocou para faixas mais baixas, que possuem taxas de motorização menores. Para cada faixa de renda, em geral, os patamares de crescimento são mantidos, sendo alterado o número de famílias naquela faixa.

Realizou-se também uma comparação das taxas de viagem dos dois grupos com Metrô, explicitando seus resultados na Tabela 5-18. 
Tabela 5-18 - Comparação das taxas de viagens por família segundo faixas de renda

\begin{tabular}{|c|c|c|c|c|c|c|c|}
\hline & & \multicolumn{6}{|c|}{ Faixas de Renda (R\$) } \\
\hline Zona & OD & $\begin{array}{r}\text { inferior a } \\
\text { R\$760,00 }\end{array}$ & $\begin{array}{c}R \$ 760,00 \\
\text { a } R \$ 1520,00\end{array}$ & $\begin{array}{c}R \$ 1520,00 \\
\text { a } R \$ 3040,00\end{array}$ & $\begin{array}{c}R \$ 3040,00 \\
\text { a } R \$ 5700,00\end{array}$ & $\begin{array}{l}\text { superior a } \\
\mathrm{R} \$ 5700,00 \\
\end{array}$ & $\begin{array}{l}\text { Média } \\
\text { Grupo }\end{array}$ \\
\hline \multirow{2}{*}{ Linha 1 - Azul } & 1997 & 2,024 & 4,487 & 6,592 & 8,191 & 9,437 & 7,234 \\
\hline & 2007 & 2,893 & 5,084 & 6,792 & 8,095 & 8,742 & 6,672 \\
\hline \multirow{2}{*}{ Linha 2 - Verde } & 1997 & 1,893 & 3,050 & 5,261 & 7,130 & 10,228 & 7,468 \\
\hline & 2007 & 3,890 & 4,837 & 6,390 & 7,683 & 11,144 & 8,130 \\
\hline \multirow{2}{*}{ RMSP } & 1997 & 3,701 & 5,765 & 7,302 & 8,371 & 9,700 & 6,895 \\
\hline & 2007 & 4,117 & 5,875 & 7,329 & 8,672 & 10,056 & 6,658 \\
\hline
\end{tabular}

Destaca-se que a taxa de viagens familiar média no Grupo com Metrô caiu de 1997 para 2007, independente das médias das faixas terem subido. Isto ocorre porque a distribuição das famílias se deslocou para faixas mais baixas, que possuem taxas de viagem menores.

As taxas de viagem por família para o Grupo com Metrô da Linha 1 - Azul aumentaram para as faixas inferiores a $R \$ 3.040,00$ e diminuíram para as faixas superiores o que denota um aumento na mobilidade individual para as faixas mais baixas uma vez que o tamanho médio da família se mantém (3,2 membros).

As famílias de todas as faixas de renda da Linha 2 - Verde tiveram aumento na taxa de viagem por família, indicando, juntamente com a redução do tamanho familiar médio para este grupo (3,1 para 2,8 membros), um aumento ainda mais acentuado na mobilidade individual.

De modo geral, neste capítulo, conclui-se que o entorno da extensão da Linha 2 - Verde não apresentou o mesmo impacto de transformações no entorno percebidas na extensão da Linha 1 - Azul.

No entanto algumas constatações podem ser feitas, a primeira delas, a redução populacional. Na Linha 1 - Azul houve redução das atividades de residência, juntamente com uma diminuição da quantidade de famílias, e o aumento de atividades de atração, indicando uma substituição de usos. Na Linha 2 - Verde ocorreu um aumento de atividades de residência, paralelamente ao aumento da quantidade de famílias e diminuição da população, resultando em famílias menores que realizam mais viagens.

A segunda constatação é o aumento das famílias nas faixas de renda médias, 
o que acontece com maior intensidade na Linha 1 - Azul, mas também pôde ser observado na Linha 2 - Verde.

O terceiro ponto a constatar é a motorização elevada do entorno das duas extensões estudadas. Neste caso a Linha 2 - Verde apresenta valores maiores, com uma motorização familiar que supera 1 automóvel/família.

O Metrô, portanto, não condicionou sozinho as alterações ocorridas. Na Linha 1 - Azul, a existência do polo de Santana, relacionado a uma fase anterior de implantação da linha, ocorreu devido ao acesso dos ônibus à estação, fomentando um comércio local e o desenvolvimento do bairro. Com a passagem de diversos ônibus para o Tucuruvi, a mesma lógica se repetiu, com o fomento a comércio e serviços locais e o surgimento de um novo polo de atração local (Passos, 2011). Na Linha 2 - Verde, por sua vez, a existência de uma zona residencial, conectada à região da Paulista pelo viário e agora pelo Metrô, próxima ao subcentro da Lapa, e com interesse das faixas de renda mais elevadas, levaram a um maior desenvolvimento residencial, de padrão mais elevado, traduzindo-se na consolidação deste local como produtor de viagens. 


\subsection{Análise desagregada}

Nesta seção, buscou-se analisar outros aspectos do comportamento das famílias que podem estar associados à implantação das estações de Metrô. Tais aspectos podem estar relacionados ao aumento da acessibilidade causado por esta infraestrutura, ou ainda, podem se relacionar a mudanças de uso do solo resultantes da proximidade da estação.

Primeiramente se avaliou a influência da proximidade da estação na posse de automóveis e, após esta análise buscou-se verificar a influência desta proximidade nas viagens das famílias.

\subsubsection{Influência da proximidade da estação na posse do automóvel}

Para avaliar a influência da proximidade da estação na posse de automóveis, realizou-se uma modelagem com Logit Binomial utilizando 2.960 famílias entrevistadas pertencentes às zonas da O/D 2007 consideradas neste estudo.

Considerou-se a posse ou não de automóvel (não tem - 0, ou tem - 1) como sendo a variável dependente desta modelagem. Algumas variáveis explicativas foram selecionadas para auxiliar na estimação do modelo. Na Tabela 5-19, observase a sua descrição mais detalhada.

Tabela 5-19 - Descrição das variáveis do modelo de posse de automóvel

\begin{tabular}{|cl|}
\hline Variável & \\
\hline Tam & Tamanho da família (Quantidade de membrição \\
Renda & Renda familiar (R\$ de Outubro de 2007) \\
DistMetrô & Distância à estação de Metrô mais próxima da residência (m) \\
Metrô & Quantidade de viagens realizadas pela família com modo principal Metrô \\
Bicicleta & Quantidade de viagens realizadas pela família com modo principal bicicleta \\
A_pé & Quantidade de viagens realizadas pela família com modo principal a pé \\
\hline
\end{tabular}

A influência da renda sobre a posse de automóvel em muitos casos é melhor representada por uma função não linear, como o logaritmo (Pfeiffer e Strambi, 2005). Assim ela foi testada da forma linear e logarítimica no modelo e a melhor especificação encontrada foi a logarítmica (InRenda).

Da mesma forma, Pfeiffer e Strambi (2005) identificaram que a influência do 
tamanho da família sobre a posse de automóvel é melhor representada como uma função de segundo grau, portanto, esta variável foi testada como linear e quadrática. A melhor especificação encontrada foi a quadrática (Tam + Tam²$^{2}$.

Viagens de metrô, a pé e de bicicleta realizadas pela família foram inseridas como proxy de variáveis atitudinais, identificando possíveis preferências de indivíduos da família com relação aos modos de transporte. Sabe-se, no entanto, que estão relacionadas à ausência da opção pelo modo automóvel entre as alternativas disponíveis. De qualquer forma, elas devem ser capazes de capturar a relação existente entre a posse de automóvel e a utilização desses outros modos, embora não seja possível estabelecer necessariamente uma relação de causalidade. De acordo com os princípios do TOD, um entorno que privilegie o caminhar, o pedalar e esteja integrado com uma rede de transportes coletivos tende a propiciar uma redução na motorização.

Para essas variáveis, duas especificações foram testadas: a quantidade de viagens; e uma versão categórica no formato "fez (1) ou não fez (0) viagem naquele modo". A melhor especificação foi encontrada para a quantidade de viagens, pois permitiu estabelecer melhor a diferença entre uma viagem pontual e um hábito da família.

Testes foram realizados para definir de que forma ocorre a influência da distância até a estação de Metrô mais próxima na posse de automóvel. Considerouse esta variável influindo de forma linear, quadrática, e também a hipótese de que a influência da estação perdesse importância quanto mais distante a estação estivesse, através do logaritmo. A melhor especificação para o modelo ocorreu para a função logarítmica (InDistMetrô).

Testou-se ainda a hipótese de que o efeito da distância esteja relacionado ao efeito de outra variável - a renda - e para tanto foram criadas variáveis dummy para representar as quatro primeiras faixas de renda ( $R 1, R 2$, $R 3$ e $R 4$ ) utilizadas anteriormente que, multiplicadas pela distância, mostrassem a influência verificada para cada faixa. A quinta faixa é representada pela própria distância sem multiplicador (faixa de referência). Esta especificação melhorou o ajuste dos modelos. 
Foram estimados modelos para três segmentos da amostra. $O$ primeiro considerando Todas as Zonas consideradas nesta dissertação, o segundo considerando somente as famílias nas Zonas com Metrô e o terceiro considerando somente as famílias do grupo de Zonas sem Metrô.

Os resultados das melhores especificações dos modelos podem ser observados na Tabela 5-20. Os coeficientes estimados representam os efeitos das variáveis sobre a possibilidade possuir automóvel e $0 \sigma$ é o desvio padrão do coeficiente. Foram assinaladas em vermelho as variáveis que não se mostraram significativas a um nível de $5 \%$ no teste t.

Tabela 5-20 - Estimativas dos modelos da posse de automóvel

\begin{tabular}{|c|c|c|c|c|c|c|}
\hline \multirow[b]{2}{*}{ Variável } & \multicolumn{2}{|c|}{ Todas as zonas } & \multicolumn{2}{|c|}{ Zonas com Metrô } & \multicolumn{2}{|c|}{ Zonas sem Metrô } \\
\hline & Coef. & $\sigma$ & Coef. & $\sigma$ & Coef. & $\sigma$ \\
\hline Intercepto & $-2,070$ & 1,190 & $-0,900$ & 1,370 & $-12,300$ & 2,690 \\
\hline Tam & 0,843 & 0,130 & 1,070 & 0,217 & 0,734 & 0,163 \\
\hline Tam $^{2}$ & $-0,100$ & 0,018 & $-0,125$ & 0,030 & $-0,093$ & 0,023 \\
\hline Metrô & $-0,171$ & 0,025 & $-0,263$ & 0,047 & $-0,121$ & 0,030 \\
\hline Bicicleta & $-0,457$ & 0,163 & $-0,410$ & 0,365 & $-0,450$ & 0,179 \\
\hline A_pé & $-0,218$ & 0,049 & $-0,155$ & 0,075 & $-0,261$ & 0,065 \\
\hline InRenda & 0,305 & 0,141 & 0,033 & 0,125 & 1,630 & 0,302 \\
\hline InDistMetrô & 0,218 & 0,083 & 0,317 & 0,160 & 0,068 & 0,184 \\
\hline R1XInDistMetrô & $-0,492$ & 0,065 & $-0,502$ & 0,093 & $-0,112$ & 0,111 \\
\hline R2XInDistMetrô & $-0,462$ & 0,050 & $-0,498$ & 0,063 & $-0,184$ & 0,085 \\
\hline R3XInDistMetrô & $-0,322$ & 0,041 & $-0,336$ & 0,054 & $-0,146$ & 0,066 \\
\hline R4XInDistMetrô & $-0,106$ & 0,039 & $-0,081$ & 0,057 & $-0,034$ & 0,056 \\
\hline \multicolumn{7}{|c|}{ Teste de razão de Verossimilhança } \\
\hline Parâmetros estimados & \multicolumn{2}{|c|}{12} & \multicolumn{2}{|c|}{12} & \multicolumn{2}{|c|}{12} \\
\hline Amostra & \multicolumn{2}{|c|}{2960} & \multicolumn{2}{|c|}{984} & \multicolumn{2}{|c|}{1976} \\
\hline Estatística teste & \multicolumn{2}{|c|}{1663,7} & \multicolumn{2}{|c|}{547,2} & \multicolumn{2}{|c|}{1154,3} \\
\hline p-valor & \multicolumn{2}{|c|}{0,000} & \multicolumn{2}{|c|}{0,000} & \multicolumn{2}{|c|}{0,000} \\
\hline \multicolumn{7}{|c|}{ Ajuste dos modelos } \\
\hline$\rho^{2}$ ajustado & \multicolumn{2}{|c|}{0,400} & \multicolumn{2}{|c|}{0,384} & \multicolumn{2}{|c|}{0,413} \\
\hline
\end{tabular}

Os testes de verossimilhança (Train, 2009) mostram que o conjunto de variáveis contribui para a explicação da posse de automóvel. Os $\rho^{2}$ ajustados (Ortuzar e Willumsen, 2010) são compatíveis aos de modelos encontrados na literatura para modelagens de transporte de cidades.

A variável Tamanho da Família (Tam e Tam²) se mostrou significativa para 
todos os três segmentos de amostra e teve o comportamento esperado, aumentando a probabilidade da posse de auto conforme aumenta a família, até um ponto de inflexão entre 4 e 5 membros, a partir do qual passa a reduzi-la (parábola com coeficiente do termo quadrático negativo).

Para as viagens de Metrô, a pé e de bicicleta, a modelagem confirma a tendência afirmada pelos defensores do TOD, pois, em geral, resultaram significativas e o aumento no uso de cada um desses modos de viagem influiu negativamente sobre a posse de auto. Isto significa que a realização de mais viagens a pé, de bicicleta ou de Metrô por uma família, está associada à redução na motorização familiar.

Especificamente nas zonas com Metrô, as viagens de bicicleta não se mostraram significativas, o que pode ser um efeito da amostra dessas viagens, que é de apenas 17 viagens distribuídas em 7 das 984 famílias.

Para o modelo de Todas as Zonas, a variável renda (InRenda) se mostrou significativa e, conforme ela aumenta, também aumenta a probabilidade da posse de automóvel. Para a amostra das zonas com Metrô, ela não se mostrou significativa, com a sua influência ocorrendo apenas através da sua interação com a distância. Para a amostra das zonas sem Metrô ela se mostrou significativa e com coeficiente maior do que para Todas as Zonas.

A variável distância (InDistMetrô) se mostrou significativa para o modelo de Todas as Zonas e para as Zonas com Metrô. Para as Zonas sem Metrô ela não se mostrou significativa, indicando que para grandes distâncias (maiores que 2000m) em relação à estação não importa estar mais perto ou mais longe dela (efeito da curva logarítmica em trecho próximo à reta constante).

Confirmou-se, através das dummy das faixas de renda, a hipótese de influência da renda sobre o efeito da distância à estação. A categoria superior é considerada como referência (omitida), assim sua influência na distância é dada pelo coeficiente da distância (InDistMetrô). Para Todas as Zonas e Zonas com Metrô, esta faixa e a faixa imediatamente inferior (R4) tratam a proximidade da estação como fator que influenciaria não possuir um automóvel e o aumento da distância como um incentivo à posse, com coeficientes positivos $(0,2$, para a referência, e 0,1 , para R4). 
As faixas de renda inferiores ( $R 1, R 2$ e $R 3$ ) apresentam coeficientes que são menores quanto menor a renda (coeficientes de - $-0,3,-0,25$ e - -0,1). A interpretação destes resultados envolve uma análise dos três fatores, renda, posse de auto e quantidades de famílias na amostra em uma determinada faixa de renda. Próximo ao Metrô, devido à valorização do uso do solo, existem poucas famílias nas faixas de renda mais baixas e muito poucas entre elas possuem automóvel. Conforme se afasta da estação, o número de famílias de renda mais baixa aumenta, mas não aumenta na mesma proporção o número dessas famílias que possui automóvel. Assim, cria-se o efeito de redução de posse de automóvel conforme ocorre o afastamento. Na realidade, o que ocorre é um aumento de famílias das faixas de renda mais baixas sem automóveis, em sua grande maioria, conforme se afasta da estação.

Conclui-se que o entorno da estação pode desincentivar a posse do automóvel para famílias de renda mais alta, assim como tende a afastar famílias de renda mais baixa.

\subsubsection{Influência da proximidade da estação nas viagens}

Buscou-se também avaliar a influência da proximidade da estação na quantidade de viagens realizada pelas famílias. Para isto realizou-se uma regressão linear, tradicionalmente utilizada para este tipo de estimação, para os mesmos segmentos de amostra da análise anterior.

A variável dependente neste caso é a quantidade de viagens realizada pela família. As variáveis explicativas utilizadas são apresentadas na Tabela 5-21.

Tabela 5-21 - Descrição das variáveis da regressão linear de viagens familiares

\begin{tabular}{|cl|}
\hline Variável & \multicolumn{1}{c|}{ Descrição } \\
\hline Tam & Tamanho da família (Quantidade de membros na família) \\
Renda & Renda familiar (R\$ de Outubro de 2007) \\
Auto & Quantidade de automóveis \\
DistMetrô & Distância à estação de Metrô mais próxima da residência $(\mathrm{m})$ \\
Matr & Quantidade de Matrículas na zona de residência \\
Emp & Quantidade de Empregos na zona de residência \\
\hline
\end{tabular}

A variável Tamanho da família foi testada como uma função linear, quadrática e logarítimica, obtendo, em geral, a melhor estimação na função quadrática (Tam + 
$\operatorname{Tam}^{2}$ ), indicando um efeito crescente sobre o número de viagens mas que perde intensidade conforme cresce o tamanho da família.

Renda familiar e quantidade de automóveis apresentam uma forte correlação e, portanto a inserção de apenas uma delas no modelo se fez necessária para minimizar problemas de multicolinearidade. Foram testadas as funções linear e logarítimica para renda, quantidade de automóveis e uma categorização da posse de automóveis. Todas as possibilidades se mostraram significativas, mas a que apresentou o melhor ajuste, com um modelo mais parcimonioso, foi a função logarítimica da renda (InRenda).

A variável Distância até a estação de Metrô mais próxima foi testada na sua forma linear e logarítmica, apresentando melhor resultado no modelo na sua forma linear (DistMetrô).

As Matrículas da zona de residência foram testadas como total e como densidade (divididas pela área da zona). Nenhuma das duas formas se mostrou significativa, assim, não foi incluída na regressão.

A variável Empregos da zona de residência foi testada de quatro maneiras: o total de empregos na zona, a densidade de empregos, somente os empregos em comércio e serviços, e a densidade de empregos em comércio e serviços. A especificação com melhor ajuste ocorreu para a densidade de empregos (DensEmp).

Os resultados das regressões lineares com as melhores especificações das variáveis explicativas podem ser observados na Tabela 5-22. Os coeficientes estimados representam os efeitos das variáveis sobre a possibilidade possuir automóvel e o $\sigma$ é o desvio padrão do coeficiente. Foram assinaladas em vermelho as variáveis que não se mostraram significativas a um nível de $5 \%$ no teste $t$. 
Tabela 5-22 - Estimativas das regressões lineares de viagens familiares

\begin{tabular}{|c|cc|cc|cc|}
\hline \multirow{2}{*}{ Variável } & \multicolumn{2}{|c|}{ Todas as zonas } & \multicolumn{2}{c|}{ Zonas com Metrô } & \multicolumn{2}{c|}{ Zonas sem Metrô } \\
\cline { 2 - 8 } & Coef. & $\sigma$ & Coef. & $\sigma$ & Coef. & $\sigma$ \\
Intercepto & $-7,865$ & 0,651 & $-9,351$ & 1,174 & $-6,952$ & 0,816 \\
Tam & 2,493 & 0,166 & 2,297 & 0,285 & 2,632 & 0,204 \\
Tam ${ }^{2}$ & $-0,083$ & 0,023 & $-0,048$ & 0,039 & $-0,105$ & 0,028 \\
InRenda & 0,918 & 0,080 & 0,979 & 0,151 & 0,844 & 0,095 \\
DistMetrô & $-0,00009$ & 0,00004 & 0,00012 & 0,00022 & $-0,00013$ & 0,00005 \\
DensEmp & 0,006 & 0,001 & 0,018 & 0,003 & 0,001 & 0,002 \\
\hline \multicolumn{7}{|c|}{ Ajuste dos modelos } \\
\hline$r^{2}$ ajustado & \multicolumn{7}{c|}{0,408} & \multicolumn{2}{c|}{0,418} & \multicolumn{2}{c|}{0,414} \\
\hline
\end{tabular}

Os valores de $r^{2}$ ajustados são considerados bons para regressão linear com dados desagregados por família (Ortuzar e Willumsen, 2010).

Para as regressões realizadas para Todas as Zonas e para as Zonas sem Metrô o Tamanho da família mostrou uma influência significativa para a função quadrática (parábola com coeficiente do termo quadrático negativo), com ponto de inflexão no entorno de 15 membros para Todas as Zonas e 12 para Zonas sem Metrô, valores superiores ao maior valor da amostra, de 10 membros. Para as Zonas com Metrô, o parâmetro $\mathrm{Tam}^{2}$ não se mostrou significativo, indicando que a influência do Tamanho da família seria linear.

A variável InRenda se mostrou significativa em todos os segmentos da amostra com um coeficiente de aproximadamente 0,9 para o termo logarítmico. Isto significa que ela influi de forma positiva, reduzindo sua relevância até um certo valor a partir do qual um incremento de renda não contribui de forma importante para um aumento de viagens (efeito relacionado à forma da curva logarítmica).

Para as Zonas com Metrô, a variável associada à distância (DistMetrô) não se mostrou significativa, indicando que nas proximidades da estação (distâncias caminháveis) não importa tanto a distância até a estação de Metrô, seja para acesso a este ou atividades no entorno deste. Para os outros grupos de zonas ela se mostrou significativa e influi negativamente nas viagens, ou seja, quanto mais longe do Metrô, menos viagens a família realiza; de forma geral para estas zonas o acesso ao Metrô é feito utilizando outro modo de transporte, tornando as viagens mais longas. 
Finalmente, a Densidade de Empregos (DensEmp) se mostrou significativa no Grupo com Metrô e influencia positivamente a quantidade de viagens, mostrando que uma diversidade de usos no entorno da residência, com empregos, comércios e serviços, induz maior quantidade de viagens que um bairro unicamente residencial. Este efeito é um dos motivos pelo qual se inclui diversidade de usos como uma das premissas do TOD.

Buscou-se ainda avaliar a influência da proximidade da estação na quantidade de viagens a pé realizada pelas famílias. Para isto realizou-se também uma regressão linear para os mesmos segmentos de amostra e variáveis explicativas da regressão para o total de viagens (vide Tabela 5-21).

Foi utilizada a mesma especificação para o Tamanho da família $\left(\operatorname{Tam}+\operatorname{Tam}^{2}\right)$ uma vez que ela se mostrou a melhor para esta regressão também.

Renda e quantidade de automóveis mais uma vez foram testados considerando todas as especificações anteriormente explicadas. Desta vez a quantidade de automóveis (Auto) mostrou o melhor ajuste e maior simplicidade no modelo, como esperado, uma vez que esta variável captura também um efeito de escolha modal.

A Distância até a estação de Metrô foi inserida buscando capturar uma possível mudança no uso do solo induzida pela presença da estação, mas não se mostrou significativa nesta regressão, mesmo na sua melhor especificação (InDistMetrô).

O mesmo ocorreu para as Matrículas (DensMatr), pois se esperaria uma relação forte entre matrículas escolares e viagens a pé.

Também os Empregos foram testados com as mesmas especificações anteriores e se escolheu a mesma especificação (DensEmp) em função do melhor ajuste obtido.

Os resultados das regressões lineares com as melhores especificações podem ser observados na Tabela 5-22. Os coeficientes estimados representam os efeitos das variáveis sobre a possibilidade possuir automóvel e $0 \sigma$ é o desvio padrão do coeficiente. Foram assinaladas em vermelho as variáveis que não se mostraram significativas a $5 \%$ no teste $t$. 
Tabela 5-23 - Estimativas das regressões lineares de viagens a pé familiares

\begin{tabular}{|c|c|c|c|c|c|c|}
\hline \multirow[b]{2}{*}{ Variável } & \multicolumn{2}{|c|}{ Todas as zonas } & \multicolumn{2}{|c|}{ Zonas com Metrô } & \multicolumn{2}{|c|}{ Zonas sem Metrô } \\
\hline & Coef. & $\sigma$ & Coef. & $\sigma$ & Coef. & $\sigma$ \\
\hline Intercepto & $-0,198$ & 0,405 & $-0,941$ & 0,775 & $-1,241$ & 0,975 \\
\hline Tam & 0,359 & 0,093 & 0,460 & 0,153 & 0,304 & 0,118 \\
\hline $\mathrm{Tam}^{2}$ & 0,049 & 0,013 & 0,028 & 0,021 & 0,059 & 0,016 \\
\hline Auto & $-0,686$ & 0,042 & $-0,756$ & 0,077 & $-0,646$ & 0,051 \\
\hline InDistMetrô & 0,036 & 0,049 & 0,159 & 0,113 & 0,163 & 0,119 \\
\hline DensMatr & $-0,0003$ & 0,0026 & $-0,0048$ & 0,0055 & $-0,0005$ & 0,0032 \\
\hline DensEmp & 0,0036 & 0,0009 & 0,0045 & 0,0019 & 0,0036 & 0,0010 \\
\hline \multicolumn{7}{|c|}{ Ajuste dos modelos } \\
\hline$r^{2}$ ajustado & \multicolumn{2}{|c|}{0,220} & \multicolumn{2}{|c|}{0,193} & \multicolumn{2}{|c|}{0,231} \\
\hline
\end{tabular}

$O \mathrm{r}^{2}$ ajustado, da ordem de 0,2 embora baixo, ainda é considerado aceitável para regressões que usam dados desagregados.

Para Todas as Zonas e Zonas sem Metrô, o Tamanho da família apresentou uma situação interessante. Ambos os coeficientes influenciam positivamente (parábola com coeficiente do termo quadrático positivo) e o ponto de inflexão aconteceria para valores negativos (para números positivos de tamanho da família o aumento é mais que linearmente proporcional). Este fato pode estar relacionado a viagens conjuntas para lazer, compras ou escola, indicando que um membro a mais, além de realizar as próprias viagens, ainda influencia outro membro a acompanhá-lo nas viagens a pé. Para as Zonas com Metrô se reproduziu o efeito linear, com o termo quadrático não sendo significativo.

O automóvel apresentou um efeito esperado: quanto maior a quantidade de automóveis, menor a quantidade de viagens realizadas a pé pela família. Cabe o mesmo comentário de causalidade, pois quanto melhores forem as condições para se realizar viagens a pé, isto pode refletir na aquisição de um automóvel, assim como a presença de um automóvel pode afetar na decisão do modo escolhido para a viagem, mesmo as mais próximas, que podem ser realizadas a pé.

A variável da distância à estação de Metrô (InDistMetrô) não se mostrou significativa, indicando que o entorno da estação não induziu atividades suficientes para se diferenciar de outras regiões da cidade e induzir as viagens a pé de seus habitantes. Esta premissa do TOD necessita de melhoria viária e de circulação que permita tornar o entorno da estação um local de atração preparado para o uso pelo 
modo a pé e sem essas melhorias, como visto na análise agregada, a proporção de viagens a pé das zonas de entorno sequer se alterou.

Como um resultado surpreendente, as Matrículas escolares da zona de residência (DensMatr) não tiveram efeito significativo sobre as viagens a pé das famílias. Talvez a variável adequada, que não foi selecionada para este estudo, fosse a quantidade de estudantes da família. Um futuro estudo sobre este tema poderia inserir esta variável que se acredita ter real influência sobre as viagens a pé.

Como ocorrido na regressão anterior, independente da presença do Metrô, a Densidade de Empregos da zona de residência (DensEmp) se mostrou significativa e influente, aumentando as viagens conforme se aumenta a oportunidade de atividades no entorno. De fato, o efeito buscado pelo TOD para o entorno de estações é fundamentado neste resultado, pois não é a proximidade à estação que atrai, mas sim o uso do solo que se propõe para seu entorno.

De modo geral, quando se permite uma lógica imobiliária que privilegia o uso do automóvel, por exemplo, inserindo-se condomínios residenciais ou torres comerciais com muitas vagas de garagem, o entorno não se torna propício ao abandono do modo individual.

Por outro lado, um incentivo aos modos coletivo e não-motorizado, com melhoria de calçadas, implantação de ciclovias, ciclofaixas, corredores exclusivos de ônibus e um bom projeto de acesso às estações pode incentivar a redução da posse e, por conseguinte, do uso do automóvel, fomentando viagens não-motorizadas, quando diversas atividades coexistem no entorno das estações, assim como viagens pelo modo coletivo devido à acessibilidade gerada pela nova estação. 


\section{Considerações finais}

Os dados analisados levam à conclusão de que o impacto causado por uma estação de metrô em uma região já estabelecida é grande provocador de transformações sociais, nem sempre caminhando na mesma direção das intenções iniciais de se instalar aquela infraestrutura no local.

Assim sendo, as relações entre os aspectos socioeconômicos e as características de viagem analisadas sugerem que a inserção deste equipamento propicia mudanças no entorno que o recebe. As mudanças causadas pela inserção de uma estação incluem uma elevação no padrão das moradias e aumento do número de serviços e comércio, como constatado por Macêdo (2010). Estes dois fatores colaboram para a redução da população do entorno, pois enquanto moradias de padrão mais alto consomem mais espaço, comércios e serviços também ocupam espaços antes destinados a residências.

A inserção da estação afeta as viagens, reduzindo sua produção no entorno quando comércios e serviços tomam espaço das residências, tornando o próprio entorno em si mais atrativo e melhorando o acesso a outras regiões para realização de atividades.

Essas mudanças parecem acontecer em maior grau quando a população do entorno é menos capaz de contestá-las, seja por não se opor às mudanças ou por não ter força política ou econômica para evitá-la, como menciona Villaça (2012).

No entorno da extensão da Linha 1 - Azul se notaram, ao longo deste estudo, transformações mais intensas, com a distribuição das famílias por faixa de renda se alterando de forma a privilegiar as faixas médias em detrimento da faixa mais baixa, sem condições de arcar com a valorização da região, assim como da faixa mais alta.

Essa valorização ocorre, entre outros fatores, por uma "aproximação de distâncias", ou seja, uma diminuição de tempo de percurso, sendo fortemente sentido em regiões que possuíam menor acessibilidade, como menciona Nigriello (1977), quando mostra que os extremos da linha são muito beneficiados com sua instalação, tanto em termos de acessibilidade quanto de valorização. Disto resulta 
que as viagens para as regiões de entorno dessas estações de extremos de linha implantadas se elevaram, fato que ocorreu com mais ênfase para as famílias de rendas médias e baixas, usuárias do transporte coletivo.

No entorno da Linha 2 - Verde tais transformações foram mais contidas, acontecendo em um grau muito menor, se comparado ao outro caso. Ainda assim elas ocorreram e foram constatadas. A influência do transporte individual nesta região, assim como a posse do automóvel, é muito mais intensa.

Para este caso, em que residências foram substituídas por outras residências, que ocuparam áreas construídas maiores e abrigaram famílias menores, houve um aumento da produção de viagens e um fortalecimento da zona como residencial.

Segundo a análise da posse de automóvel, o percentual mais baixo de uso de transporte coletivo nas zonas que receberam metrô, associado aos índices socioeconômicos analisados dessas zonas, permite concluir que o maior poder aquisitivo dos moradores das zonas de entorno do Metrô permite a eles a posse e, por consequência, uso do automóvel mais intenso.

Ainda assim, foi possível apontar na análise desagregada que a proximidade a uma estação do Metrô diminui a probabilidade da posse do automóvel nas faixas de renda mais elevadas, o que pode ocorrer com maior intensidade ao se planejar o seu entorno privilegiando outros modos.

Quando se permite um desenvolvimento urbano que privilegie o uso do automóvel, o entorno não se torna propício ao "abandono" do modo individual. Por outro lado, um incentivo aos modos coletivo e não-motorizado pode agir de forma a reduzir a posse e, por conseguinte, o uso do automóvel.

Um melhor planejamento do entorno de novas estações do Metrô, levando em consideração premissas do TOD pode trazer benefícios não só de acessibilidade, aproximando os habitantes de seus destinos e fomentando também viagens a pé.

Os resultados desta dissertação podem auxiliar 0 direcionamento do planejamento do entorno de novas estações na cidade de São Paulo e talvez em outras cidades que possuam uma lógica semelhante, lembrando que a valorização das regiões com Metrô em São Paulo se deve em muito à estruturação de espaço 
que este equipamento, escasso na cidade, realiza.

Pesquisas futuras nessa área podem abranger novas estações, verificando como se deu o desenvolvimento de seu entorno, ou ainda, aprofundando relações decorrentes da inserção de um equipamento de transportes e mudanças em seu entorno.

Elas podem ainda se focar em pontos mais específicos deste trabalho, como as relações das viagens a pé com o entorno de estações, verificando se locais onde 0 entorno foi planejado visando o pedestre e o modo coletivo apresentam resultados diferentes dos aqui encontrados.

Pode-se ainda buscar uma relação entre a posse de automóvel e locais que apresentem redes mais consolidadas de transportes coletivos, permitindo também uma comparação com os casos apresentados nesta dissertação. 


\section{Referências Bibliográficas}

ANDRADE, M. A.; ALVES MAIA, M. L. The Recife Metro - the Impact on Urban Development after 20 years. Flux 2009/1, n, 75, p 57-68, Paris, 2009.

BIERLAIRE, M. (2003). BIOGEME: A free package for the estimation of discrete choice models , Proceedings of the 3rd Swiss Transportation Research Conference, Ascona, Switzerland.

Bierlaire, M. (2008). An introduction to BIOGEME Version 1.6, biogeme.epfl.ch

$\mathrm{CAO}, \mathrm{X}$. Exploring causal effects of neighborhood type on walking behavior using stratification on the propensity score. Environment and Planning A, 42(2), 487-504, 2010.

CERVERO, R. Built environment and mode choice: toward a normative framework. Transp. Res. Trans. Environ. Part D, Oxford, v. 7, n. 8, 2002.

CORREIA, R. L. O que é espaço urbano? Quem produz espaço urbano? In Espaço Urbano. Ática, (7-35), São Paulo, 1989.

DEÁK, C. Solução é investimento em sistema de transporte rápido de massa. Entrevista ao Portal da Prefeitura de São Paulo, Especial: SP 450 anos, São Paulo, 2004.

ESTADO DE SÃO PAULO, Secretaria dos Transportes. Manual da Pesquisa Origem Destino 1997. São Paulo, 1997.

ESTADO DE SÃO PAULO, Secretaria dos Transportes. Manual da Pesquisa Origem Destino 2007. São Paulo, 2007.

EWING, R., \& CERVERO, R. Travel and the built environment. Transportation Research Record, 1780: 87-114, 2001.

EWING, R., \& CERVERO, R. Travel and the Built Environment. Journal of the American Planning Association, Vol. 76, Issue 3, 2010.

GIL, A. C., Como elaborar projetos de pesquisa. Atlas, 4를 Edição, São Paulo, 2002

GUIMARÃES, T. Desenvolvimento de um indicador de acessibilidade para a avaliação de projetos de transporte da perspectiva da exclusão social: A Linha 6 do metrô de São Paulo. XXV ANPET, Belo Horizonte, 2011.

HANDY, S. L. Accessibility- X mobility-enhancing strategies for addressing automobile 
dependence in the U.S. European Conference of Ministers of Transport, 2002.

MACÊDO, N. de C. Uma análise sobre os impactos decorrentes da inserção de estações metroviárias em áreas urbanas. Dissertação de mestrado. Escola Politécnica - USP, São Paulo 2010.

MILAKIS, D. Relationships between Urban Form and Travel Behavior in Athens, Greece. A Comparison with Western European and North American Results. European Journal of Transport and Infrastructure Research, Vol. 8, Issue 3, 2007.

MOSQUEIRA, T. Reabilitação da Região da Luz - Centro histórico de São Paulo. Dissertação de Mestrado. FAU-USP, São Paulo, 2007

NIGRIELLO, A. O valor do solo e sua relação com a acessibilidade. Dissertação de Mestrado. UFRJ, Rio de Janeiro, 1977.

NIGRIELLO, A. Conservar para desenvolver: estudo sobre o patrimônio urbano construído. Tese de Doutorado. FAU-USP, São Paulo, 1987.

ORTUZAR, J de D.; WILLUMSEN, L. G. Modelling Transport. Willey, Chichester, 2011.

PARRAS, F. R. Aportes para a melhoria da gestão de Transporte Público por ônibus de Bogotá a partir de experiências de Belo Horizonte e Curitiba. Dissertação de Mestrado. PUCPR, Curitiba, 2006.

PASSOS, L. R. P. Estruturação da Região Metropolitana de São Paulo em 2007 - Qual a utilidade do conhecimento sobre a estrutura urbana? XVIII Congresso de Transporte e Trânsito, CT157, Pg. 1165, Rio de Janeiro, 2011.

PFEIFFER, L. M. \& STRAMBI, O. Análise e modelagem da evolução temporal da posse de autos na Região Metropolitana de São Paulo. Revista Transportes vol. XIII, n. 1, p. 21-29, 2005.

SALON, D. Cars and the city: An investigation of transportation and residential location choices in New York City. Tese de Doutorado. Universidade da Califórnia, Davis, 2006.

SOCIAL EXCLUSION UNIT Making the connections: final report on transport and social exclusion. Cabinet Office (UK Government), Londres, 2003.

TAKANO, M. S.; SILVA, A. H.; TACO, P. W. G. How the Establishment of a Metro System changed land use patterns in the Metropolitan Region of Brazilian Federal District. XI CUPUM, Paper 233, 2009.

TRAIN, K. E. Discrete Choice Methods with Simulation. Cambridge University Press, $2^{\mathrm{a}}$ 
Edição, Cambridge, 2009.

VILLAÇA, F. Reflexões sobre as cidades brasileiras. São Paulo: Nobel, 2012.

ZHOU, B., \& Kockelman, K. Self-selection in home choice: Use of treatment effects in evaluating relationship between built environment and travel behavior. Transportation Research Record, 2077, 54-61, 2008.

ZMITROWICZ, W. A estruturação da cidade pelas rotinas urbanas. Tese de Livre Docência. Escola Politécnica - USP, São Paulo, 1997.

\section{Páginas de Internet}

http://www.metro.sp.gov.br/redes/azul/tetucuruvi.shtml (acessado em 28/11/2011). http://www.metro.sp.gov.br/redes/azul/tejardimsp.shtml (acessado em 28/11/2011). http://www.metro.sp.gov.br/redes/azul/teparada.shtml (acessado em 28/11/2011). http://www.metro.sp.gov.br/redes/verde/tesumare.shtml (acessado em 28/11/2011). http://www.metro.sp.gov.br/redes/verde/temadalena.shtml (acessado em 28/11/2011). http://www.transitorienteddevelopment.org (acessado em 06/02/2012). http://www.newurbanism.org (acessado em 06/02/2012). http://www.curitiba.pr.gov.br (acessado em 13/02/2012) http://www.viagemfacil.com.br/1014/bogota-colombia (acessado em 13/02/2012) http://www.metro.sp.gov.br/metro/numeros-pesquisa/pesquisa-origem-destino1997.aspx (acessado em 10/10/2012).

http://www.metro.sp.gov.br/metro/numeros-pesquisa/pesquisa-origem-destino2007.aspx (acessado em 10/10/2012).

http://ww2.prefeitura.sp.gov.br/secretarias/desenvolvimentourbano/plano diretor/inte gra/formato do arquivo.pdf (acessado em 13/02/2013).

http://www.portalaction.com.br/ (acessado em 16/02/2013).

http://biogeme.epfl.ch/ (acessado em 06/03/2013). 